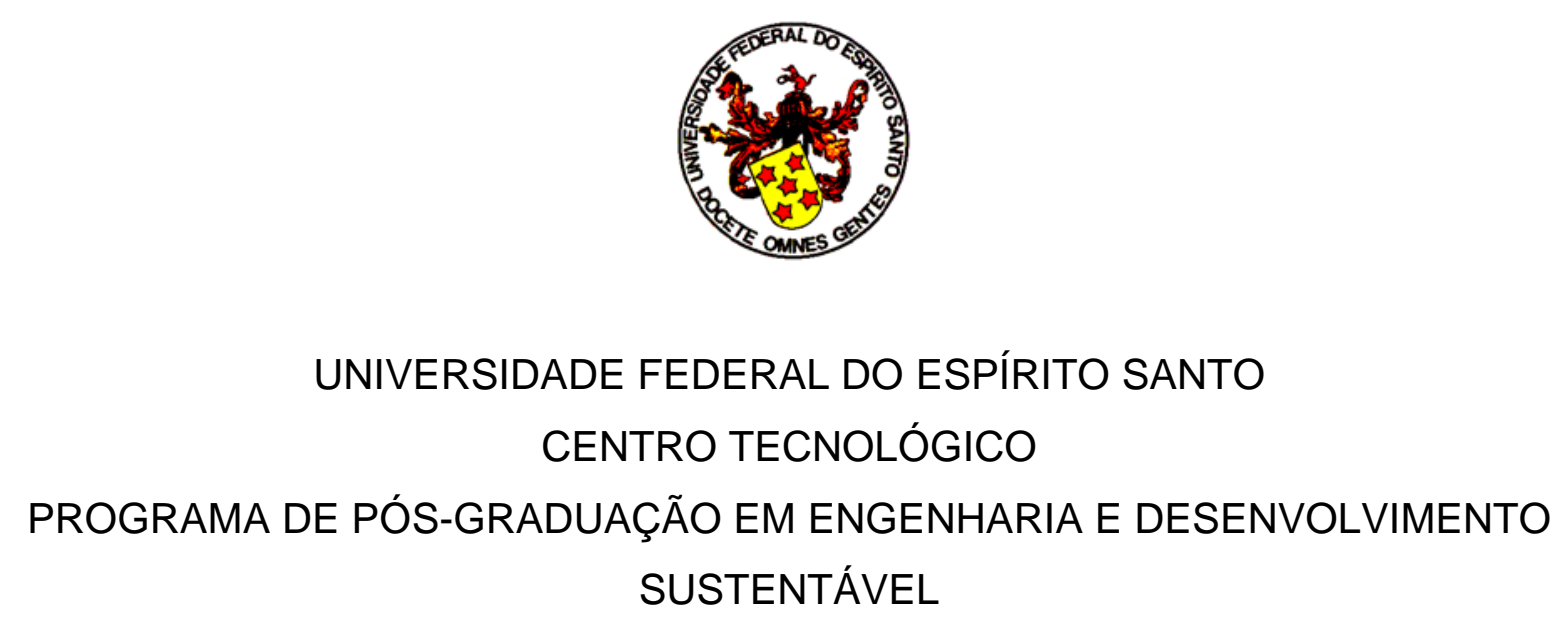

PAULO VITOR REIS KAMINICE

GERENCIAMENTO DE RESÍDUOS SÓLIDOS DE UMA INDÚSTRIA GRÁFICA COM ENFOQUE EM PRODUÇÃO MAIS LIMPA (P+L): ESTUDO DE CASO NO ESPÍRITO SANTO

VITÓRIA 


\section{GERENCIAMENTO DE RESÍDUOS SÓLIDOS DE UMA INDÚSTRIA GRÁFICA COM ENFOQUE EM PRODUÇÃO MAIS LIMPA (P+L): ESTUDO DE CASO NO ESPÍRITO SANTO}

Dissertação de Mestrado apresentado ao Programa de Pós-graduação em Engenharia e Desenvolvimento Sustentável do Centro Tecnológico da Universidade Federal do Espírito Santo, como requisito para obtenção do grau de Mestre em Engenharia e Desenvolvimento Sustentável na linha de pesquisa de impactos ambientais e soluções sustentáveis - tratamento de resíduos.

Orientador: Prof. Dr. Gilson Silva Filho

VITÓRIA 
Dados Internacionais de Catalogação-na-publicação (CIP)

(Biblioteca Setorial Tecnológica,

Universidade Federal do Espírito Santo, ES, Brasil)

Kaminice, Paulo Vitor Reis, 1986-

K15g Gerenciamento de resíduos sólidos de uma indústria gráfica com enfoque em produção mais limpa $(\mathrm{p}+\mathrm{l})$ : estudo de caso no Espírito Santo / Paulo Vitor Reis Kaminice. - 2017.

$110 \mathrm{f}$. : il.

Orientador: Gilson Silva Filho.

Dissertação (Mestrado em Engenharia e Desenvolvimento Sustentável) - Universidade Federal do Espírito Santo, Centro Tecnológico.

1. Resíduos sólidos - Gerência. 2. Indústria gráfica. 3. Produção mais limpa. I. Silva Filho, Gilson. II. Universidade Federal do Espírito Santo. Centro Tecnológico. III. Título.

CDU: 628 


\title{
GERENCIAMENTO DE RESÍDUOS SÓLIDOS DE UMA INDÚSTRIA GRÁFICA COM ENFOQUE EM PRODUÇÃO MAIS LIMPA (P+L): ESTUDO DE CASO NO ESPÍRITO SANTO
}

\begin{abstract}
Dissertação de Mestrado apresentado ao Programa de Pós-graduação em Engenharia e Desenvolvimento Sustentável do Centro Tecnológico da Universidade Federal do Espírito Santo, como requisito para obtenção do grau de Mestre em Engenharia e Desenvolvimento Sustentável na linha de pesquisa de impactos ambientais e soluções sustentáveis - tratamento de resíduos.
\end{abstract}

Aprovado em 31 de março de 2017.

\author{
COMISSÃO EXAMINADORA
}

Prof. Dr. Gilson Silva Filho

Orientador - PPGES / UFES

Prof. ${ }^{a}$ Dra. Rosane Hein de Campos

Examinadora interna - PPGES / UFES

Prof. Dr. Edison Thaddeu Pacheco

Examinador externo - Centro Universitário São Camilo / ES 
Dedico à minha mãe, madrinha, professores e amigos. 


\section{AGRADECIMENTOS}

Agradeço à Universidade Federal do Espírito Santo (UFES), pelo ensino e infraestrutura disponibilizados.

À Gráfica VV pelo interesse e busca da melhoria contínua de seus processos, melhoria do controle da poluição, qualidade ambiental e ocupacional.

Aos colegas do PPGES, pelo apoio e troca de experiências profissionais.

Às empresas Engeo Soluções Integradas, Imetame Energia, Elementus Soluções.

À Pedecão Pet Shop, pela parceria e incentivo.

Aos amigos Miraya Dutra e Victor Hugo.

Ao orientador professor Dr. Gilson Silva Filho pela credibilidade, suporte e orientação. 


\section{RESUMO}

No segmento industrial gráfico, dentre os impactos ambientais causados pela geração de poluição, a geração de resíduos sólidos torna-se fator preocupante, dado a relação de sua geração com o desperdício de matérias-primas, aumento de custos de produção e reduzida eficiência no processo industrial, o que exerce influência sobre a valoração do produto final, sobre a rentabilidade econômica destes produtos e a competitividade da indústria no mercado. Desta forma, a otimização da produção industrial é fator decisivo para competitividade e permanência no mercado. A redução da geração de poluição, mitigação dos impactos ambientais e a otimização de processos, em sua forma preventiva, está ancorada na Política Nacional de Resíduos Sólidos, Lei n 12.305/2010. O gerenciamento de resíduos sólidos industriais pode se tornar estratégia corporativa para prevenção da geração de poluição e que traduz-se em ações de otimização da produção e melhoria contínua, o que relaciona-se a metodologia de Produção Mais Limpa $(\mathrm{P}+\mathrm{L})$. Assim, o objetivo desta pesquisa foi diagnosticar o gerenciamento de resíduos sólidos com enfoque nas premissas da metodologia de $\mathrm{P}+\mathrm{L}$ em uma indústria gráfica e implementar um Programa de Gerenciamento de Resíduos Sólidos (PGRS) visando a otimização da produção industrial, equilíbrio sustentável dos processos e redução da geração de resíduos sólidos. Constatou-se que a gráfica em estudo teve a oportunidade de entender a importância do PGRS, da adoção de valores ecoeficientes e valor funcional ao fluxo do processo industrial, consolidando, portanto, as técnicas implementadas. A contribuição do PGRS pode ser observada pelo desempenho positivo das ações implementadas, que resultou num equilíbrio entre o consumo de matérias-primas e a geração de resíduos sólidos, possibilitando agregar valor ao produto final. A sinergia das ações implementadas, pautadas na integração do PGRS e $P+L$, possibilitou a melhoria do desempenho ambiental da gráfica, interferindo positivamente no desempenho operacional com a adequada operacionalização industrial. Os resultados apresentados sugerem que as indústrias do segmento gráfico e demais setores industriais explorem a metodologia adotada, adotando o PGRS como ferramenta de um sistema gestão ambiental integrado.

Palavras-chave: Gerenciamento de Resíduos Sólidos. Produção Mais Limpa. Indústria Gráfica. 


\begin{abstract}
Solid waste generation in the printing industries represents a serious problem, as well as being related to the reduce production performance, increase of production costs, material losses and also environmental aspects and impacts. The industrial production optimization is a decisive factor for competitiveness, anchored in the Brazilian Solid Waste Law (n 12.305/2010). Solid Waste Management Plan has become corporate strategy for industrial pollution prevention and correlates into optimization actions and continuous improvement in industrial process, associated to cleaner production (CP) methods and sustainable production practices. Therefore, the purpose of this research was, by the case study, to diagnose solid waste management focusing cleaner production methodology and legal prerogatives, also implement a solid waste management plan. All productive processes was evaluated at printing industry, aiming the opportunity to understand the importance of continuous improvement processes based on the environmental and economic impacts reduction, resulting in the adoption of ecoefficient values, best operational and organizational culture practices, adding economic value to the final product, such as functional value at printing industry production process. Waste Management Plan contribution can be observed by the positive performance in the industrial process, which resulted in an optimization between the consumption of raw materials and solid waste generation, adding greater value to the product and also the addition of financial resources through recyclable solid waste sales. The synergy between waste management plan and cleaner production methodology improves the environmental performance, operational performance and optimizated production process at printing industry. The results suggest that printing industries and other industrial sector explore the methodology adopted, integrating cleaner production with waste management plan, developing an integrated environmental management system tool.
\end{abstract}

Keywords: Solid Waste Management. Cleaner Production. Printing Industry. 


\section{LISTA DE FIGURAS}

Figura 1 - Fluxograma de classificação e caracterização de resíduos sólidos .........41

Figura 2 - Representação da Impressora digital, presente na gráfica $\mathrm{VV}$................58

Figura 3 - Representação da Copiadoras, presentes na gráfica VV ......................58

Figura 4 - Representação da Processadora de chapas, presente na gráfica VV ......58

Figura 5 - Representação da Impressora Offset 4 cores, presente na gráfica VV ....58

Figura 6 - Representação da Impressora Offset 2 cores presente na gráfica VV .....59

Figura 7 - Representação da Dobradeira presente na gráfica VV ..........................59

Figura 8 - Representação da Guilhotina, presente na gráfica VV .........................59

Figura 9 - Representação da Montagem, presente na gráfica VV .........................59

Figura 10 - Representação da Encadernadora, presente na gráfica VV .................59

Figura 11 - Representação da Embaladora, presente na gráfica VV ......................59

Figura 12 - Fluxograma do processo industrial praticado na Gráfica VV ................61

Figura 13 - Gráfico de geração de resíduos sólidos .......................................77

Figura 14 - Gráfico de consumo x geração de RS de Papel/Papelão .....................78

Figura 15 - Acondicionamento de RS em meio ao processo de produção................79

Figura 16 - Acondicionamento de RS em meio ao processo de produção.................79

Figura 17 - Segregação incorreta com contaminação entre tipos de RS .................79

Figura 18 - Coletor de RS (saco de fibra ao fundo da figura) ............................79

Figura 19 - Coletor de resíduos perigosos ............................................... 81

Figura 20 - Coleta de resíduos perigosos ................................................. 81

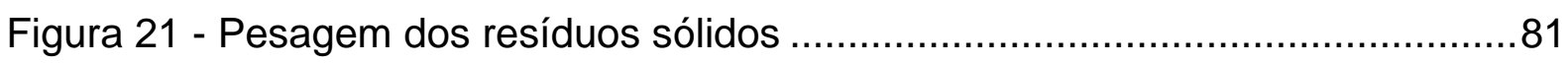

Figura 22 - Registro dos resíduos sólidos pesados........................................ 81

Figura 23 - Local externo à sala de armazenamento de resíduos sólidos ...............82

Figura 24 - Parte interna da sala de armazenamento de resíduos sólidos ..............82

Figura 25 - Adequação da infraestrutura para armazenamento temporário RS ........83

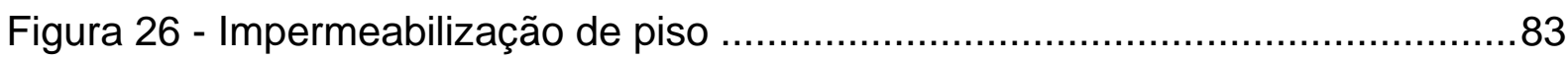

Figura 27 - Armazenamento de RS perigosos ........................................... 83

Figura 28 - Gráfico de desempenho quanto a redução da geração de RS ...............87

Figura 29 - Gráfico de desempenho quanto à forma de destinação final dos RS .....90

Figura 30 - Gráfico de ecoeficiência do processo industrial ...............................93 


\section{LISTA DE QUADROS}

Quadro 1 - Exemplos de indicadores de processo para avaliação.........................32

Quadro 2 - Equipamentos do processo industrial......................................57

Quadro 3 - Atividades do processo participativo do gerenciamento de RS com enfoque

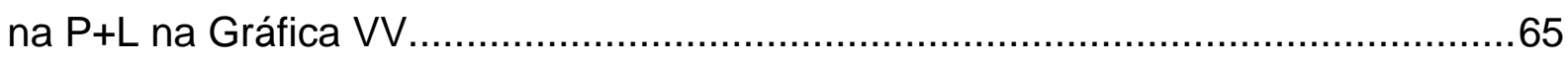

Quadro 4 - Caracterização do empreendimento .......................................68

Quadro 5 - Matérias-primas, em quilogramas, utilizados durante o processo de

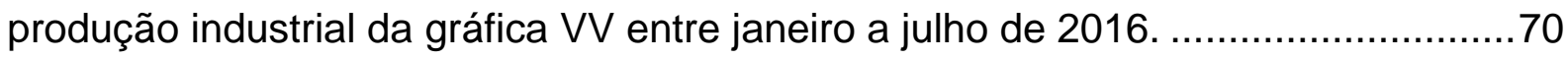

Quadro 6 - Insumos diversos, em quilogramas, utilizados durante o processo de produção industrial da gráfica $\mathrm{V} V$ entre janeiro a julho de $2016 . \ldots \ldots \ldots \ldots \ldots \ldots \ldots \ldots \ldots . . .70$

Quadro 7 - Consumo de água e energia elétrica durante o processo de produção

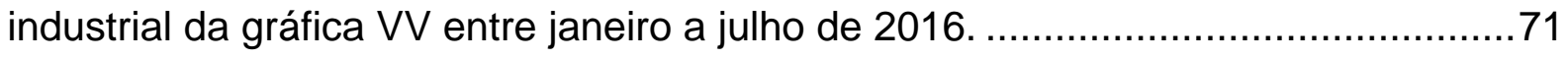

Quadro 8 - Tipos de resíduos sólidos gerados durante o processo de produção

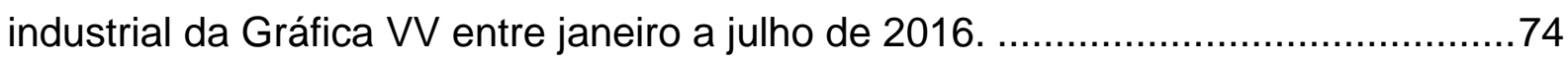




\section{LISTA DE TABELAS}

Tabela 1 - Quantificação dos resíduos sólidos gerados durante o processo de produção industrial da Gráfica WV entre janeiro a julho de $2016 \ldots \ldots \ldots \ldots \ldots \ldots \ldots \ldots \ldots . . . \ldots \ldots$

Tabela 2 - Indicador da geração de resíduos sólidos por matéria-prima consumida na

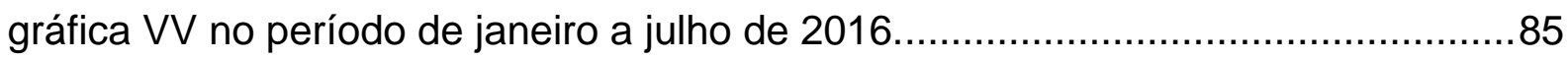

Tabela 3 - Indicador do tipo de destinação final aplicada aos resíduos sólidos gerados durante os meses de janeiro a julho de 2016. 89

Tabela 4 - Indicador da evolução do consumo de matérias-primas e insumos utilizados pela gráfica VV, durante os meses de janeiro a julho de 2016. 


\section{LISTA DE SIGLAS}

ABIGRAF - Associação Brasileira da Indústria Gráfica

ABRELPE - Associação Brasileira de Resíduos e Limpeza

ABNT - Associação Brasileira de Normas Técnicas

ABTG - Associação Brasileira de Tecnologia Gráfica

BNDES - Banco Nacional de Desenvolvimento Econômico e Social

CEBDS - Conselho Empresarial Brasileiro para o Desenvolvimento Sustentável

CEMPRE - Compromisso Empresarial para a Reciclagem

CERFLOR - Programa Brasileiro de Certificação Florestal

CETESB - Companhia de Tecnologia de Saneamento Ambiental do Estado de São Paulo

CNTL - Centro Nacional de Tecnologias Limpas

CONAMA - Conselho Nacional do Meio Ambiente

FSC - Forest Stewardshio Council (Concelho de Manejo Florestal)

IBAMA - Instituto Brasileiro do Meio Ambiente e dos Recursos Renováveis

ISO - International Organization for Standardization (Organização Internacional de Normalização)

MP - Matérias Primas

NBR - Denominação de norma da Associação Brasileira de Normas Técnicas (ABNT)

ONU - Organização das Nações Unidas

PCP - Programa de Controle da Poluição

PERS - Política Estadual de Resíduos Sólidos

PGRS - Programa de Gerenciamento de Resíduos Sólidos

PIA - Printing Industries Association

PNRS - Política Nacional de Resíduos Sólidos 
PPGES - Programa de Pós-graduação em Engenharia e Desenvolvimento Sustentável

$\mathrm{P}+\mathrm{L}$ - Produção Mais Limpa

RS - Resíduos Sólidos

RSI - Resíduos Sólidos Industriais

RSU - Resíduos Sólidos Urbanos

RS-DC - Resíduos Sólidos diversos contaminados

RS-NC - Resíduos Sólidos não contaminados

SBS - Sociedade Brasileira de Silvicultura

SISNAMA - Sistema Nacional do Meio Ambiente

SNVS - Sistema Nacional de Vigilância Sanitária do Brasil

SGA - Sistema de Gestão Ambiental

SUASA - Sistema Unificado de Atenção à Sanidade Agropecuária

TR - Termo de Referência

UNEP - United Nations Environmental Program

USEPA - United States Environmental Protection Agency 


\section{SUMÁRIO}

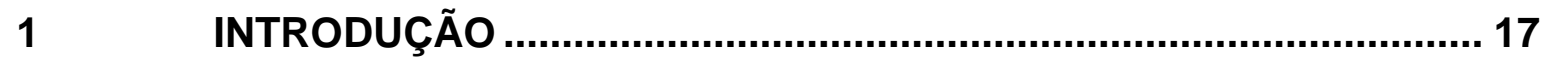

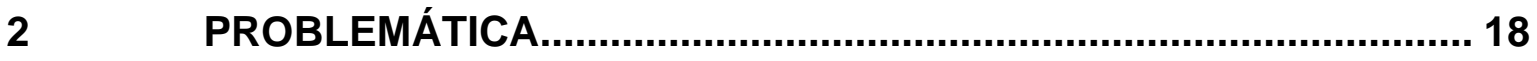

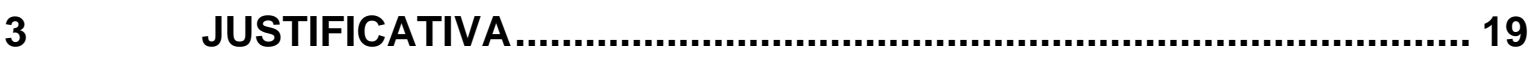

4 OBJETIVOS

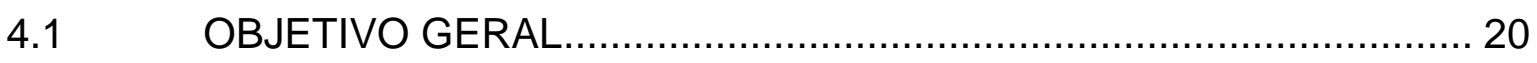

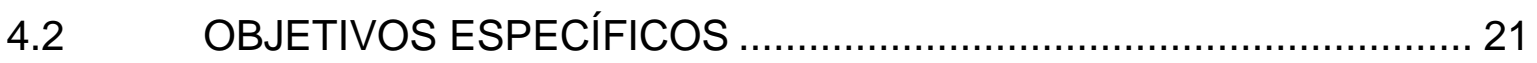

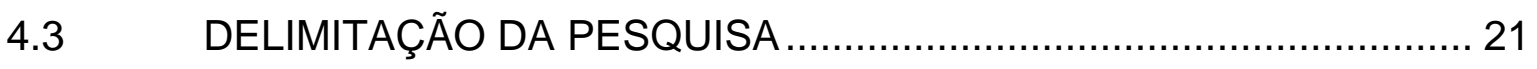

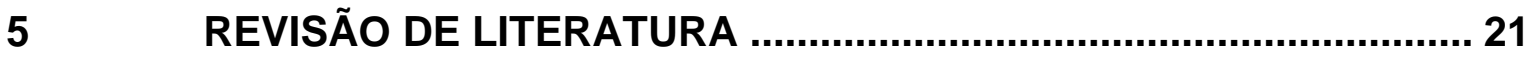

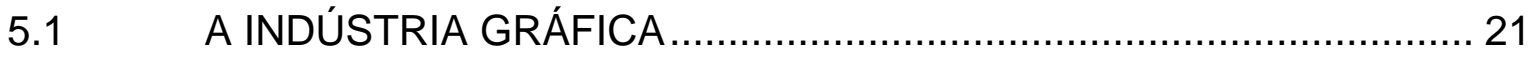

5.1.1 A indústria gráfica no Brasil...................................................... 21

5.1.2 Características da indústria gráfica ................................................ 23

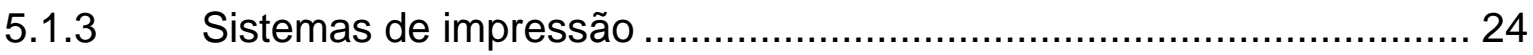

5.1.4 Consumo de matérias-primas e insumos ……….............................. 25

5.1.5 Processo produtivo da indústria gráfica............................................ 26

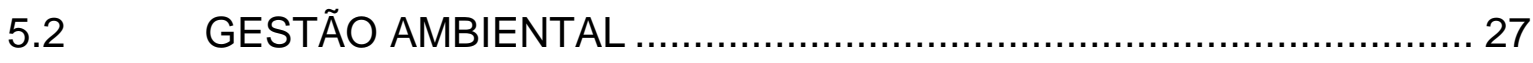

5.2.1 Gestão Ambiental na indústria gráfica ............................................ 28

5.2.1.1 Conselho de Manejo Florestal (FSC) ……….............................. 28

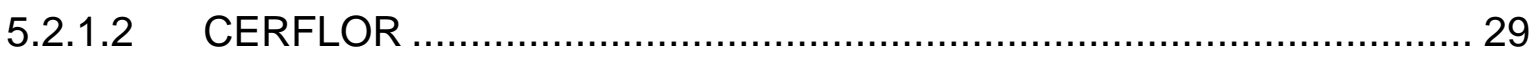

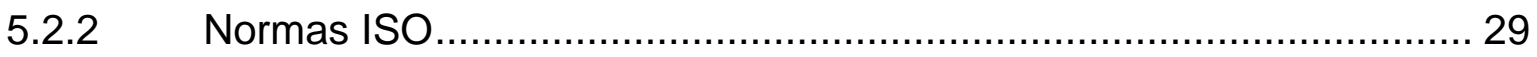

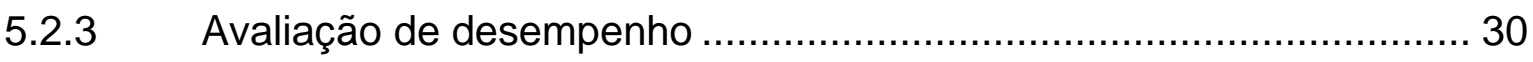

5.2.4 Indicadores de desempenho ambiental........................................... 31

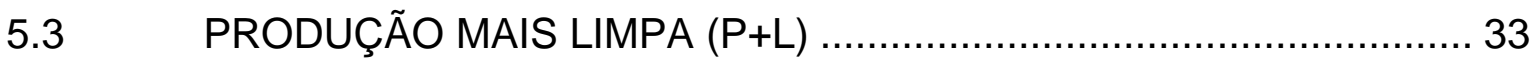

5.3.1 Exemplos de resultados alcançados com a implantação da $\mathrm{P}+\mathrm{L}$........ 36

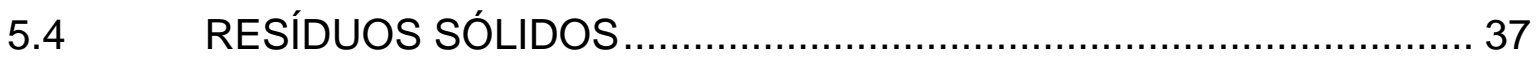


5.4.1 Identificação e classificação dos resíduos sólidos .............................. 38

5.5 GERENCIAMENTO DE RESÍDUOS SÓLIDOS ................................. 43

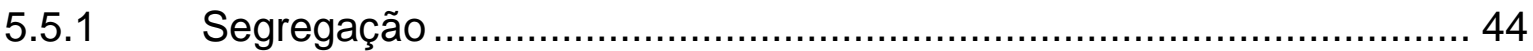

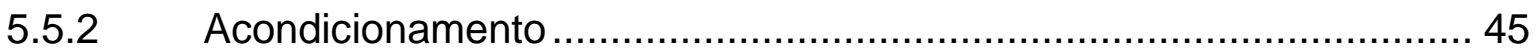

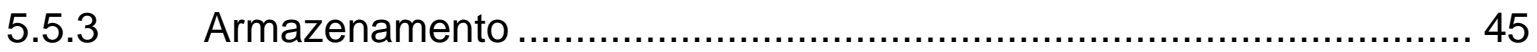

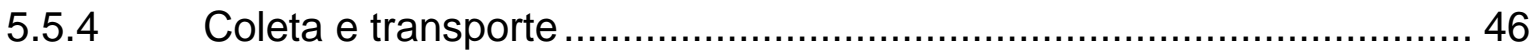

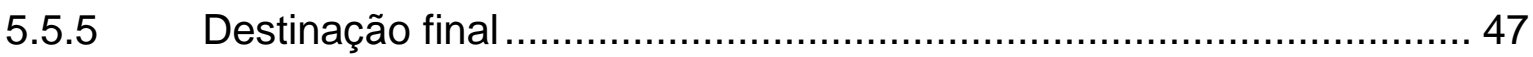

5.6 PROGRAMA DE GERENCIAMENTO DE RESÍDUOS SÓLIDOS....... 47

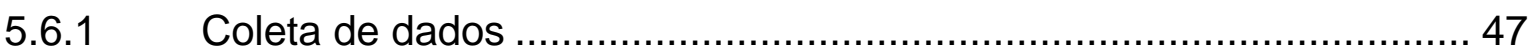

5.6.2 Diagnóstico do gerenciamento de resíduos sólidos ............................ 48

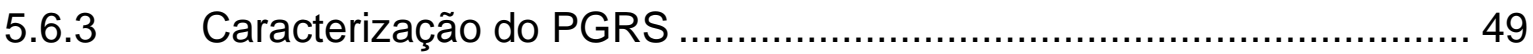

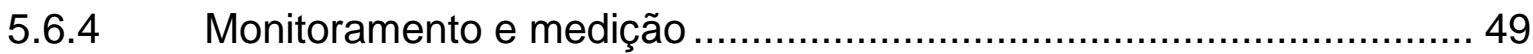

5.7 LEGISLAÇÕES E NORMAS GERAIS APLICÁVEIS …........................ 50

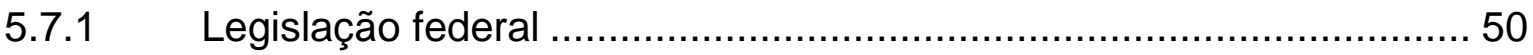

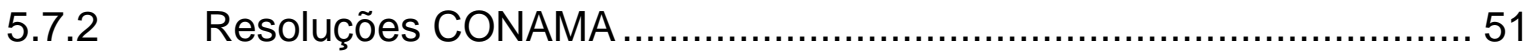

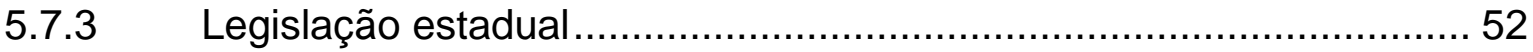

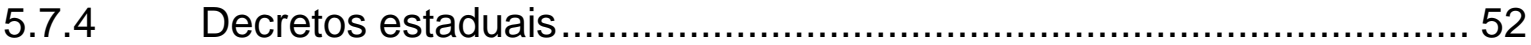

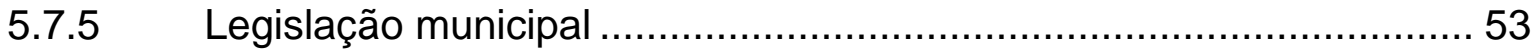

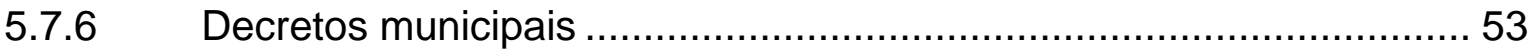

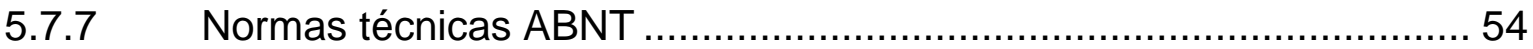

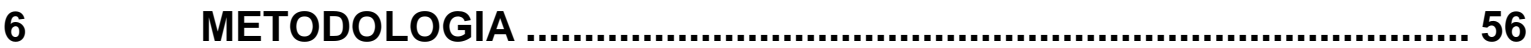

6.1 COLETA DE DADOS PARA CARACTERIZAÇÃO E DIAGNOSE DO

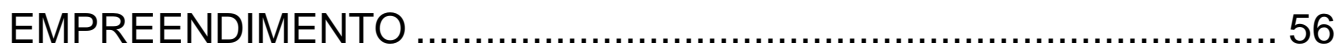

6.1.1 Levantamento dos equipamentos e sistema de impressão ................ 57

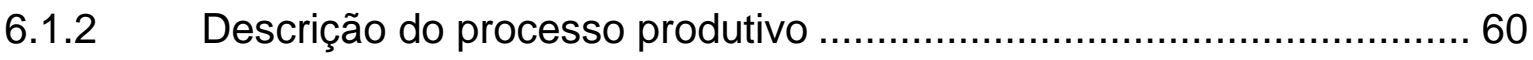

6.2 DIAGNÓSTICO DO GERENCIAMENTO DE RESÍDUOS SÓLIDOS .. 62 
6.2.1 Geração dos resíduos sólidos ………........................................... 62

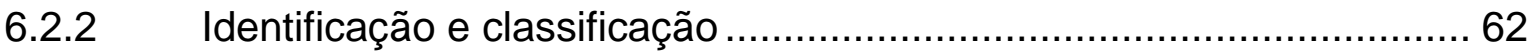

6.2.3 Acondicionamento e armazenamento ……….................................... 63

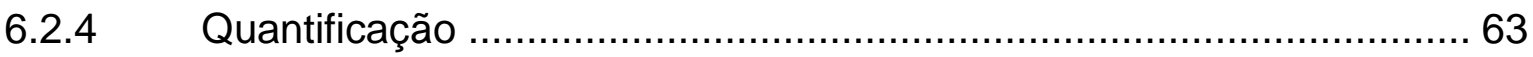

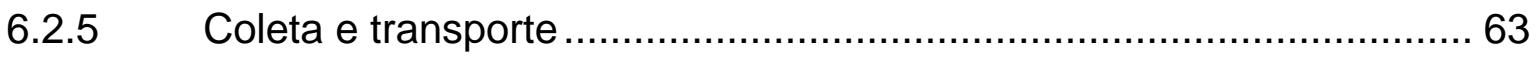

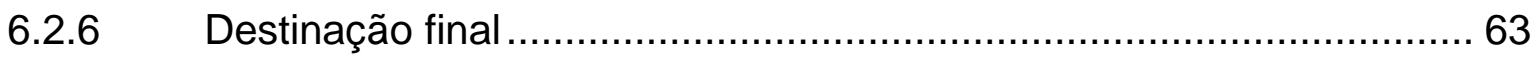

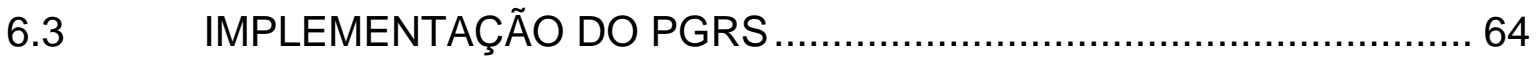

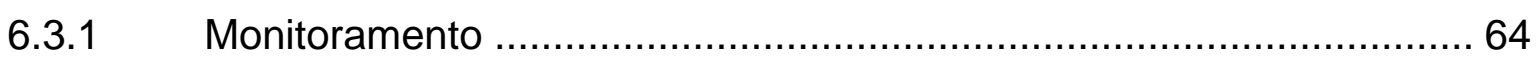

6.4 AVALIAÇÃO DE DESEMPENHO DA IMPLEMENTAÇÃO DO PGRS 66

6.4.1 Indicadores de desempenho ambiental........................................... 66

6.4.1.1 Indicador da geração de RS por matéria-prima consumida ................ 66

6.4.1.2 Indicador do tipo de destinação ambientalmente adequada ............... 67

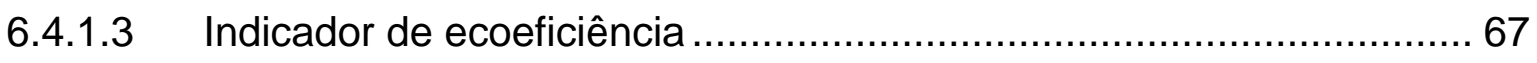

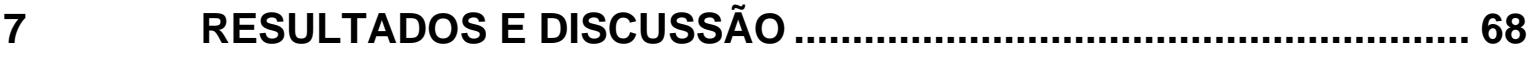

7.1 CARACTERIZAÇÃO DA INDÚSTRIA GRÁFICA VV........................... 68

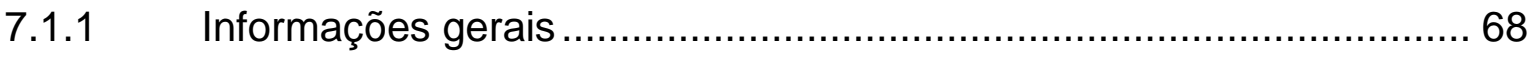

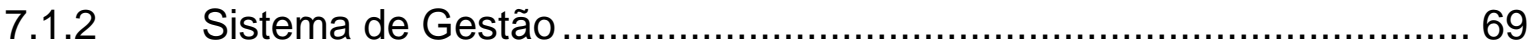

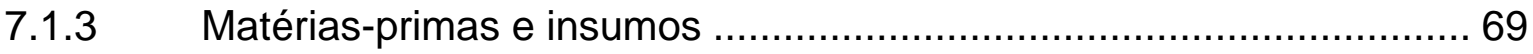

7.1.4 Oportunidades de melhoria do processo industrial............................ 72

7.2 DIAGNÓSTICO DO GERENCIAMENTO DE RESÍDUOS SÓLIDOS

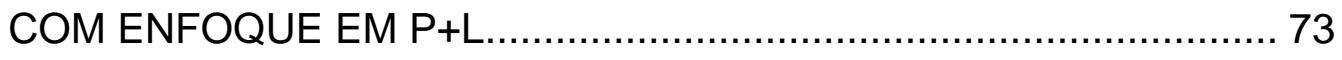

7.2.1 Geração de resíduos sólidos ......................................................... 73

7.2.2 Segregação e acondicionamento …………….............................. 78

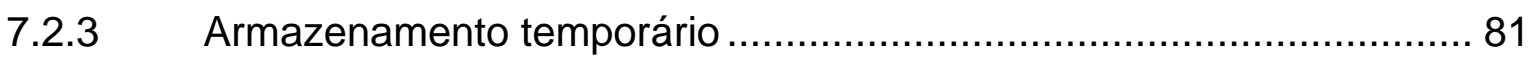

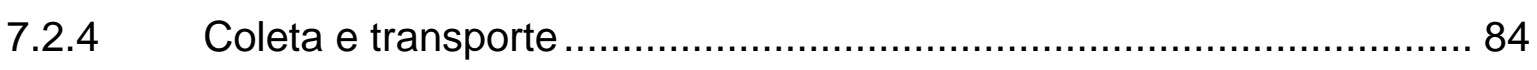

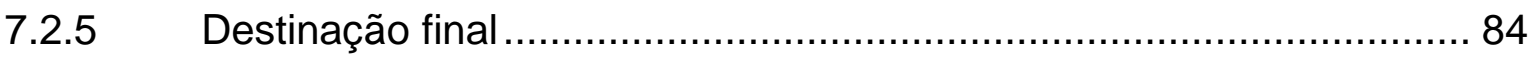


7.3 AVALIAÇÃO DO DESEMPENHO DA IMPLEMENTAÇÃO DO PGRS 85

7.3.1 Indicador da geração de resíduos sólidos por MP consumida ............ 85

7.3.2 Indicador do tipo de destinação ambientalmente adequada ............... 88

7.3.3 Indicador de ecoeficiência quanto ao consumo de MP e insumos ...... 90

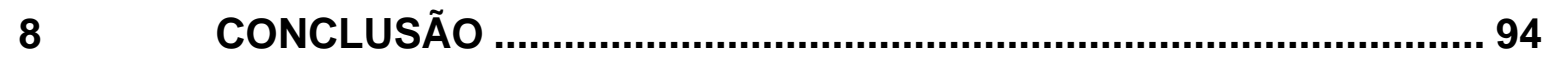

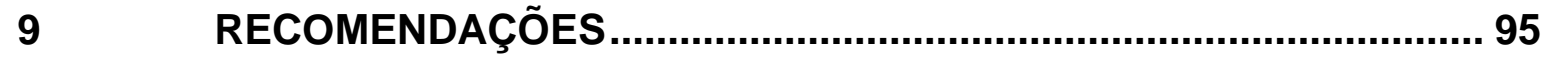

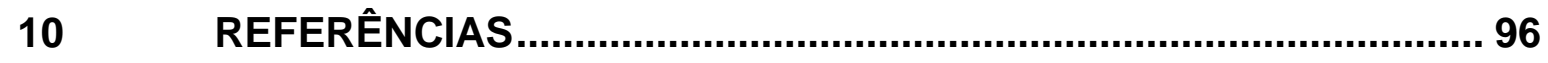

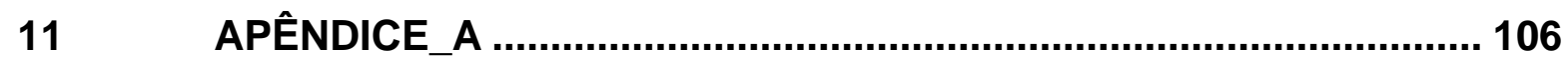

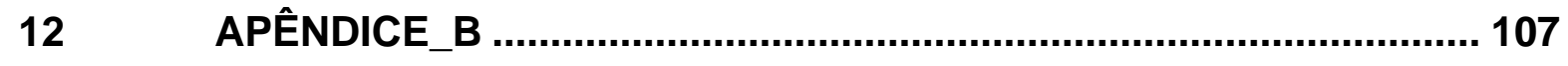

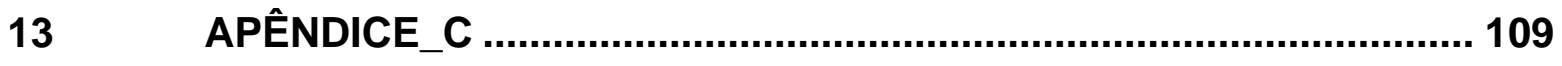

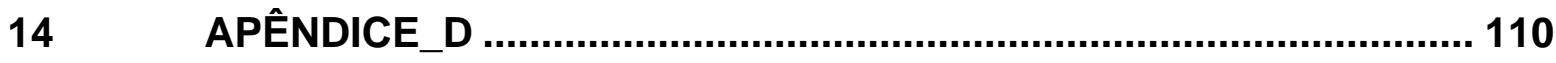


1 INTRODUÇÃO

A indústria gráfica é um segmento industrial dinâmico, envolve as atividades relacionadas com a reprodução de informações diversas e que passa por transformação imposta por um nicho de mercado altamente competitivo. A medida da evolução industrial e a necessidade de rapidez para divulgação e reprodução de impressos, é inerente ao processo industrial o aumento da geração de resíduos maior predisposição à poluição ambiental (NAIME; GARCIA, 2004).

O elevado volume de resíduo produzido, quando não gerenciado de forma correta, proporciona a diminuição de receita da indústria pelo desperdício de matérias-primas e a geração de poluição ambiental, sendo necessário o adequado gerenciamento destes para reduzir o desperdício e a poluição causada pelos resíduos produzidos, possibilitando proteger, conservar e melhorar a qualidade do meio ambiente, contribuir para a saúde humana, saúde ocupacional e assegurar uma utilização prudente e racional dos recursos naturais, bem como promover valor sustentável agregado ao produto final industrial (SIMIÃO, 2011).

A otimização da produção industrial de forma preventiva está ancorada na Política Nacional de Resíduos Sólidos (PNRS), Lei no 12.305/2010 que define (inciso X, art. $3^{\circ}$ ) o gerenciamento de resíduos sólidos como um "conjunto de ações exercidas, direta ou indiretamente, nas etapas de coleta, transporte, transbordo, tratamento e destinação final ambientalmente adequada dos rejeitos". Nesse contexto, a adoção de um sistema de gerenciamento de resíduos sólidos que represente um plano de gestão eficiente e que combinado com ações e práticas da metodologia de Produção Mais Limpa $(\mathrm{P}+\mathrm{L})$ pode contribuir para melhorar o fluxo operacional, otimizar a produção e a utilização de insumos no processo industrial, a redução da geração dos resíduos sólidos e também possibilitar o aumento de valor agregado ao produto final do empreendimento (HINZ; VALENTINA; FRANCO, 2006).

A Produção Mais Limpa $(\mathrm{P}+\mathrm{L})$ é uma importante aliada ao gerenciamento dos resíduos sólidos, pois trata da aplicação de uma estratégia técnica, econômica e ambiental integrada aos processos e produtos, visto que possui como objetivo aumentar a eficiência no uso de matérias-primas, água e energia, através da não geração, minimização ou reciclagem dos resíduos e emissões geradas, com 
benefícios ambientais, de saúde ocupacional e econômicos (CNTL, 2003; ABIGRAF, 2009; BOUSQUIM; ESTERMAN; ROTHENBERG, 2011; PIMENTA; GOUVINHAS, 2012).

Considerando a geração de resíduos como fruto da ineficiência dos processos, a $\mathrm{P}+\mathrm{L}$ evidencia-se como instrumento de fomento à melhoria contínua das atividades produtivas, podendo abarcar desde as tecnologias empregadas nos processos até a própria gestão da empresa (LIMA; RUTKOWSKI, 2009), o que corrobora com Bare e outros (2000), em que destacam o gerenciamento de resíduos sólidos como ferramenta para otimização e controle dos processos industriais, e também redução de impacto ambiental.

Desta forma, visando maior produtividade, menor desperdício, redução na geração de resíduos sólidos e da poluição em geral este estudo de caso teve com finalidade avaliar o desempenho do gerenciamento de resíduos sólidos alicerçados às práticas da $\mathrm{P}+\mathrm{L}$ direcionadas à realidade de uma indústria gráfica, conduzindo à prática rotineira de ações e adoção de valores ecoeficientes, possibilitando agregar valores ao ambiente de trabalho, ao processo industrial e ao produto final.

\section{PROBLEMÁTICA}

Os recursos naturais e não renováveis devem ser consumidos de forma racional e as questões ambientais devem ser consideradas como uma parte do desenvolvimento de produto, processos industriais ou serviços (KUBOTA; ROSA, 2013).

O crescente consumo de bens e serviços, o aumento de produção industrial e, consequentemente, o aumento na produção dos resíduos industriais e a falta de gerenciamento adequado são fatores que geram impactos negativos ao meio ambiente (BALDIN; ORTH; ZANOTELLI, 2014). Mesmo pequenas indústrias, que numa primeira análise parecem não provocar problemas ambientais, podem causar sérios prejuízos em caso do gerenciamento incorreto do seu processo produtivo ou pela má administração dos recursos naturais (SANTOS; YAMANAKA; PACHECO, 2005). 
De acordo com Terra e Wassermam (2013), no segmento da indústria gráfica a geração de resíduos sólidos é problema grave e está relacionado às perdas de produção e também aos demais aspectos e impactos ambientais, indicando a adoção da $\mathrm{P}+\mathrm{L}$ como estratégia de gestão aplicada ao controle de resíduos sólidos.

Portanto, a implementação do PGRS com enfoque em $\mathrm{P}+\mathrm{L}$ na indústria gráfica localizada na cidade de Vila Velha, estado do Espírito Santo, otimizará sua produção, reduzirá os danos ao ambiente, minimizará a geração de resíduos sólidos e possibilitará aumento de valor agregado ao seu produto final?

\section{JUSTIFICATIVA}

As empresas buscam ações e medidas que as auxiliem na minimização dos impactos ambientais e na maximização dos lucros por meio de gerenciamento correto da sua atividade fim, pautado principalmente no ajuste de processos, produtos e na sustentabilidade ambiental pela redução dos resíduos gerados e dos impactos negativos ao ambiente (SILVA; MEDEIROS, 2004; CHAVAN, 2005; CAGNO; TRUCCO; TARDINI, 2005; KLEMES; VARBANOV; HUISING, 2012; KUBOTA; CAMPOS; CAUCHICK-MIGUEL, 2014).

As questões ambientais são cada vez mais presentes nos processos industriais e tem sido considerada como oportunidade para agregação de valores à produção, com maior rendimento e lucro.

O artigo 20 da Lei $n^{\circ}$ 12.305/2010 referente à Política Nacional de Resíduos Sólidos - PNRS, estabelece que os geradores de resíduos industriais devem elaborar o Programa de Gerenciamento de Resíduos Sólidos (PGRS). Assim, na busca de atender as exigências da Lei, as indústrias buscam gerenciar os resíduos sólidos gerados para evitar a contaminação do meio ambiente, com correto manejo, transporte e destinando-os de maneira adequada, priorizando a diminuição da geração de poluição, eliminação de desperdícios e estabelecendo uma política de gestão que garanta uma forma adequada de operacionalização industrial. Contudo considerando os aspectos e impactos ambientais de um processo industrial, a complexidade e abrangência do PGRS quanto à sistematização na prevenção da 
poluição, uma política de gestão efetiva deve abordar não apenas o atendimento às premissas legais, mas o contexto do desenvolvimento sustentável e tomadas de decisões e estratégias ecoeficientes.

Segundo Dias (2004, p. 92) se apenas um segmento da sustentabilidade (Desenvolvimento Econômico, Social e Ambiental) se destacar, o equilíbrio perfeito para o desenvolvimento sustentável é perdido. Assim a $\mathrm{P}+\mathrm{L}$ associado ao sistema de gerenciamento de resíduos sólidos pode, em quanto atuante, proporcionar a manutenção dessa sustentabilidade, pois busca o equilíbrio dos pilares da sustentabilidade (HINZ; VALENTINA; FRANCO, 2006; WANG; YAN; HU, 2016).

Desta forma, o diagnóstico do gerenciamento de resíduos sólidos com enfoque na $\mathrm{P}+\mathrm{L}$ possibilita fornecer o suporte necessário para incorporar a ideia de melhoria contínua, com o envolvimento de todos os colaboradores, multiplicação das valores ecoeficientes, possibilitando adequação da empresa na busca da eficiência competitiva e melhor desempenho ambiental.

Nesse sentido, o estudo de caso de uma indústria gráfica é justificado pela necessidade de atendimento às legislação específica e oportunidade de implementação de um PGRS embasado no diagnóstico do gerenciamento de resíduos sólidos com enfoque na $\mathrm{P}+\mathrm{L}$, não restringindo-se somente às ações para atendimento à legislação e condicionantes ambientais, alcançando valores sólidos e restabelecendo a rotina no empreendimento.

O estudo de caso é viável e importante para o setor da indústria gráfica, pois é inédito no Espírito Santo, e inédito considerando a sinergia das técnicas de gestão ambiental quanto à implantação integrada do PGRS com enfoque em P+L.

\section{OBJETIVOS}

\subsection{OBJETIVO GERAL}

Diagnosticar o gerenciamento de resíduos sólidos e implementar um Programa de Gerenciamento de Resíduos Sólidos (PGRS) com enfoque nas premissas da 
metodologia da Produção Mais Limpa $(P+L)$ em uma indústria gráfica, visando a otimização da produção industrial, equilíbrio sustentável dos processos, minimização da geração de resíduos sólidos e redução dos danos ao ambiente.

\subsection{OBJETIVOS ESPECÍFICOS}

- Realizar a coleta de dados para diagnose do gerenciamento de resíduos sólidos da Indústria Gráfica VV;

- Executar o diagnóstico do gerenciamento de resíduos sólidos com enfoque em $\mathrm{P}+\mathrm{L}$;

- $\quad$ Implementar o PGRS na Indústria Gráfica VV;

- $\quad$ Avaliar o desempenho ambiental e a contribuição da implementação do PGRS.

\subsection{DELIMITAÇÃO DA PESQUISA}

O estudo foca o gerenciamento dos resíduos sólidos industriais gerados no processo produtivo da Gráfica VV, não contemplando os demais resíduos sólidos gerados em outras áreas, como, por exemplo, os resíduos sólidos administrativos, efluentes líquidos e atmosféricos.

5 REVISÃO DE LITERATURA

\subsection{A INDÚSTRIA GRÁFICA}

\subsubsection{A indústria gráfica no Brasil}

O Brasil teve sua primeira gráfica oficialmente instalada no ano de 1.808, sendo esta denominada de Imprensa Régia, localizada no Rio de Janeiro e instalada por D. João 
VI (ABIGRAF, 2009). A indústria gráfica brasileira completou 209 anos de existência em 2017, e vem contribuído de maneira significativa para o progresso socioeconômico do país.

As informações do setor são reunidas e apresentadas pela Associação Brasileira das Indústrias Gráficas - ABIGRAF, sendo ano de 2015 registradas um total de 19.999 gráficas no país. Dentre as regiões brasileiras a região Sudeste apresentou maior quantitativo de gráficas registradas na ABIGRAF, contando com 9.464 indústrias gráficas e 118.434 empregos gerados, e a região Norte com o menor número de empreendimentos, sendo 782 gráficas e 5.285 empregos gerados (ABRIGRAF, 2017). As diferenças de participação da indústria gráfica nas regiões brasileiras são relacionadas com o desenvolvimento de cada região, considerando que quanto mais dinâmica e desenvolvida a região, mais serviços e produtos da indústria são requisitados no mercado.

O perfil da indústria gráfica brasileira aponta que $81 \%$ do setor são representadas por empresas de micro porte e 16,2\% de empresas de pequeno porte, onde em média a microempresa tem de 0 a 9 funcionários e a empresa de pequeno porte tem em média de 10 a 49 funcionários (ABIGRAF, 2017).

Acompanhando o movimento generalizado de queda da economia brasileira nos três primeiros meses do ano de 2015, em que o PIB do país recuou 0,2\% e a produção da indústria de transformação registrou queda de 7,9\% em relação ao mesmo período do ano de 2014, o setor gráfico recuou 3,7\% na mesma comparação sendo o recuo diretamente relacionado ao cenário econômico nacional, que deixou estagnado quase todos os segmentos da indústria (ABIGRAF, 2015). Entretanto, a estimativa de produção em faturamento previsto para a indústria gráfica brasileira colocará o Brasil como o oitavo país do mundo em faturamento para o segmento gráfico com $U \$ 20$ bilhões, superando aos 2\% de crescimento no setor (ABIGRAF, 2017).

O aumento no setor da indústria gráfica já era previsto caso houvesse reduções dos impactos ambientais, trabalho para a minimização de consumos de substâncias tóxicas, matérias primas, água e energia, e reduções nas gerações de resíduos só lidos, efluentes líquidos, emissões atmosféricas, ruídos e vibrações (SINDGRAF, 2006). Assim, tais aumentos no setor sugerem uma melhor adaptação e adequação 
das indústrias gráficas às diretrizes estabelecidas na Lei $n^{0}$ 12.305/2010 e demais premissas legais e normativas quanto à prevenção da geração de poluição.

A implantação de novos empreendimentos e aumento do setor pode ser observado quanto ao panorama de investimentos realizados, sendo que no ano de 2011 foram importados 1.282,8 máquinas e equipamentos, avançando em uma queda anual, apresentando em 2016 apenas 514,7 máquinas e equipamentos importados para o Brasil (ABIGRAF, 2017).

\subsubsection{Características da indústria gráfica}

A indústria gráfica é muito diversificada, atende a todos os setores da economia incluindo serviços públicos, privados, serviços financeiros, publicitários, editoriais, prestadores de serviços e a indústria de manufatura em geral (SOUZA; SILVA, 2008). Para atender as demandas tão diferenciadas, a indústria gráfica possui diferentes processos de produção, desde a produção de embalagens, publicações, impressos promocionais, de segurança, fiscais, formulários, etiquetas, cadernos, pré-impressão, cartões, envelopes, pôsteres, faixas etc. (SOUZA; SILVA, 2008; ABIGRAF, 2017).

O volume da produção gráfica pode ser adequadamente mensurado, contudo, as informações não são agregáveis visto que são tomadas como referência as medidas unitárias produzidas, não sendo possível somar tais números a fim de se obter um panorama global do setor. Sendo assim, outros indicadores podem auxiliar na análise do desempenho da indústria gráfica, como por exemplo, o consumo de tintas para impressão, o consumo de embalagens, o consumo de papel, e a evolução das vendas de livros, revistas e jornais possibilitam inferir o desenvolvimento do setor gráfico nos segmentos correspondentes (MACEDO; VALENÇA, 1997).

Em estudo aplicado por Castillo e Leão (2014) das 456 empresas gráficas em atividade no estado de Pernambuco, não mais de quarenta são consideradas médias ou grandes empresas, sendo que a maioria dessas empresas possuem menos de 10 funcionários, e analisando sete gráficas no estado, apenas duas possuíam licenciamento ambiental. 
As características de um produto gráfico são definidas pelo material principal (suporte), o tamanho (formato), a quantidade (tiragem), as cores e os acabamentos, dentro os produtos da indústria, o segmento de embalagens corresponde a $40 \%$ de participação no setor de produção, seguido de publicações (livros, revistas, manuais, guias) com 29,2\%, impressos promocionais com 9,8\%, formulários com 6,7\% e demais produtos (ABIGRAF, 2015).

De acordo com o levantamento realizado pela ABTG em 2008, junto a diversas gráficas, a quantidade de resíduos destinados a aterros varia de $0,7 \mathrm{~kg}$ a $7 \mathrm{~kg}$ por tonelada produzida, a quantidade de resíduos coprocessados varia de $0 \mathrm{~kg}$ a $40 \mathrm{~kg}$ por tonelada produzida e geração de resíduos de aparas de produção varia de 5\% a 36\% do volume produzido (SINDIGRAF, 2006).

De acordo com a Revista Técnica do Setor Gráfico Brasileiro, Edição 67, (2009) (acesso em junho de 2015), uma empresa gráfica gera resíduos algo em torno de 6\% a $7 \%$ de sua produção.

Em relatório elaborado pela Printing Industries Association (PIA, 2003), abrangendo Estados Unidos e Austrália, a associação com mais 2000 empreendimentos vinculados apontou uma média de $12 \%$ de taxa de geração de resíduos sólidos sobre a produção industrial.

\subsubsection{Sistemas de impressão}

De acordo guia técnico ambiental da indústria gráfica (SINDIGRAF, 2006) os seis sistemas de impressão mais comum na indústria gráfica são: offset, rotogravura, flexografia, tipografia, serigrafia e impressão digital, sendo descrito sucintamente cada um deles:

Offset: É um sistema de impressão indireto onde a fôrma/fotolito é uma chapa metálica gravada com uma imagem. Depois de entintada, essa imagem é transferida para um cilindro intermediário, conhecido como blanqueta e, através desta blanqueta, transferida para o substrato (papel).

A impressão offset é o sistema mais usado para a impressão de livros, periódicos, pôsteres, promocionais, brochuras, cartões, rótulos e embalagens, ou rotativa, 
comumente usada para a impressão de jornais, livros, tabloides, revistas, catálogos, periódicos, promocionais.

Rotogravura: A rotogravura é um sistema direto de reprodução gráfica, em que o substrato entra em contato com a fôrma/fotolito de impressão, onde a imagem é gravada em baixo-relevo em um cilindro metálico e a transferência se dá através da pressão entre os cilindros e o substrato.

Flexografia: Flexografia é um sistema de impressão direta que utiliza fôrmas flexíveis, feitas de borracha ou polímero, com as áreas de grafismo em alto-relevo. A impressão é realizada diretamente sobre o substrato utilizando tintas fluidas, voláteis e de secagem rápida.

Tipografia: A tipografia é, possivelmente, o mais antigo dos sistemas de impressão direta e caracteriza-se pelo uso de fôrmas gravadas em alto-relevo, que transferem a tinta das áreas elevadas diretamente para o substrato. Em geral são usados tipos móveis, montados de acordo com o texto que se deseje imprimir.

Serigrafia: Serigrafia é um sistema de impressão direta que utiliza como fôrma uma tela de tecido, plástico ou metal, permeável à tinta nas áreas de grafismo e impermeabilizada nas áreas de contragrafismo. Sobre essa tela, montada numa moldura, a tinta é espalhada e forçada com auxílio de uma lâmina de borracha de modo a chegar ao substrato.

Impressão digital: Entende-se por impressão digital qualquer sistema de impressão no qual a imagem é gerada a partir de um arquivo digital e transferida diretamente para uma impressora, que pode ser, por exemplo, a laser, jato de tinta.

\subsubsection{Consumo de matérias-primas e insumos}

A atividade de uma gráfica utiliza vários insumos em seus processos, sendo eles: energia, tintas, água e matérias-primas, que atuam no processo direta ou indiretamente. Solventes, filmes, reveladores, goma e adesivos são exemplos de matérias-primas que atuam indiretamente, pois não são essenciais na elaboração de todos os produtos. 
Em geral, são utilizados na atividade industrial gráfica (SEBRAE, 2012):

Água: utilizado em banhos de pré-impressão, serigrafia, sistemas de resfriamento;

Energia: utilizado para alimentação de máquinas e equipamentos elétricos;

Tintas: utilizadas no processo de impressão, compostas por resinas, pigmentos, aditivos;

Substratos: trata-se do material onde será impressa a imagem do produto, sendo o mais comum a utilização de papel, de diversas características;

Matriz I Forma: chapas metálicas, cilindros de rotogravura ou outro modelo portador de imagem;

Outros insumos: solventes de limpeza, filmes, reveladores, fixadores, soluções químicas, colas.

\subsubsection{Processo produtivo da indústria gráfica}

O processo produtivo é um conjunto de operações e etapas envolvidas na materialização de qualquer projeto gráfico, desde um simples cartão de visita, até livros, brochuras, folhetos, embalagens, rótulos, cartazes, dentre tantos outros que combinam vários tipos de materiais e técnicas (MEDEIROS, 2013).

De acordo com o Guia Técnico Ambiental - Série P+L (CNTL, 2003), descreve-se abaixo uma visão geral sobre esse processo industrial gráfico:

Pré-impressão: A pré-impressão representa o início do processo industrial gráfico e inclui uma sequência de operações que permitem a passagem da arte a ser impressa do seu original para o portador de imagem, também conhecido como fôrma/fotolito.

Existem duas alternativas tecnológicas para esta etapa de pré-impressão, a analógica e a digital. Na digital, a transferência da imagem para a fôrma/fotolito é feita diretamente do computador (gravação) enquanto na impressão analógica a transferência é feita indiretamente, de forma manual ou mecanizada. 
Impressão: A impressão é a principal etapa da indústria gráfica e consiste na transferência da imagem, contida na fôrma/fotolito, para um substrato.

Pós-impressão: A pós-impressão consiste em dar acabamento (corte/dobra, verniz, outros tratamentos), conversão (colagem, laminação, picotagem, perfuração) e distribuição (embalo, etiquetagem, expedição).

\subsection{GESTÃO AMBIENTAL}

No ano de 1981 foi promulgado a Política Nacional do Meio Ambiente (PNMA) - Lei $\mathrm{n}^{\circ}$ 6.938, de 31 de agosto de 1981, e no ano de 1988 promulgado na Constituição da República Federativa do Brasil capítulo dedicado ao meio ambiente como forma de promoção da sustentabilidade ambiental mediante análise da relação entre a gestão ambiental e gestão de operações.

É fundamental a definição do significado de gestão ambiental para um empreendimento (JABBOUR et al., 2012), por meio de diretrizes voltadas para as atividades de gerenciamento industrial visando a obtenção de resultados positivos em relação ao meio ambiente, reduzindo ou eliminando os danos ambientais causados pela atividade da empresa (BARBIERI, 2007).

Segundo Haden, Oyler e Humphreys (2009, p. 1052), a gestão ambiental é definida como:

[...] o processo de aplicação de inovação para alcançar a sustentabilidade, a redução da geração de resíduos, a responsabilidade social, e uma vantagem competitiva via aprendizagem contínua e desenvolvimento, ao considerar metas e objetivos ambientais como estratégias de negócio.

Para a adequação do processo produtivo da indústria gráfica aos procedimentos de gestão ambiental é necessário a elaboração de um programa de redução de resíduos, e de organizar equipes para acompanhar constantemente 0 andamento do planejamento e das tecnologias utilizadas no processo produtivo (SOUZA; SILVA, 2008), que conduz boas práticas operacionais para melhor gestão do ambiente de forma estratégica (REDMOND, et al., 2008). 
Para melhorar o desempenho ambiental de uma empresa, muitas vezes, é necessário aplicar medidas onerosas que não angariam benefícios financeiros óbvios e diretos para a mesma. Por conta disso, as questões ambientais não eram priorizadas pelas organizações (SOUTO; RODRIGUEZ, 2015).

A gestão ambiental caracteriza-se pela busca da melhoria contínua do sistema de produção e possibilita às organizações uma melhor condição de gerenciamento de seus aspectos e impactos ambientais, além de interagir e intervir no clima organizacional e nas atitudes e na cultura da empresa (NASCIMENTO, 2012).

Para o Centro Nacional de Tecnologia Limpa (CNTL, 2003), a implantação de sistemas de gestão ambiental e de técnicas que visem a produção mais limpa nas empresas está principalmente relacionada à eficiência no processo produtivo, sendo medidas em termos de recursos financeiros economizados em relação ao investimento realizado (CNTL, 2003; REAP et al., 2008a,b).

Para a implantação de um Sistema de Gestão Ambiental (SGA), que visa à diminuição do impacto ambiental oriundo dos produtos e processos da organização, o gerenciamento de resíduos é um dos itens importantes (CARDOSO, 2008), pois sempre busca a redução da geração de resíduos, seu correto tratamento e destinação final. Nesse processo de gestão de resíduos e da produção industrial, as diretrizes da $\mathrm{P}+\mathrm{L}$ são essencialmente importantes para a garantia da sustentabilidade ambiental e da empresa (HINZ; VALENTINA; FRANCO, 2006).

\subsubsection{Gestão Ambiental na indústria gráfica}

\subsubsection{Conselho de Manejo Florestal (FSC)}

Em adicional às premissas da NBR ISO 14.001, umas das práticas de gestão ambiental da indústria gráfica relaciona-se com a aquisição de matéria prima através de certificação de origem florestal, conhecido como FSC - Forest Stewardship Council (Conselho de Manejo Florestal) (SINDIGRAF, 2006).

O FSC é um órgão internacional que atua na análise de gestão e qualidade da indústria gráfica, emitindo certificação quanto ao rastreamento total da matéria-prima 
(madeira florestal) (SEBRAE, 2012). A certificação consiste em um selo em Cadeia de Custódia, referente a um processo usado para manter, documentar e garantir a idoneidade e o rastreamento da matéria-prima da floresta em todas as etapas industriais até chegar ao consumidor final (SEBRAE, 2012).

\subsubsection{CERFLOR}

Também com objetivos similares do FSC, a Sociedade Brasileira de Silvicultura SBS, em parceria com algumas associações do setor, instituições de ensino e pesquisa, organizações não-governamentais e com apoio de alguns órgãos do governo brasileiro, vem trabalhando desde o ano de 1996 com um programa voluntário denominado CERFLOR - Programa Brasileiro de Certificação Florestal (INMETRO, acesso em junho de 2015).

O objetivo da certificação é conciliar a exploração dos recursos da floresta e a preservação de seus recursos naturais, ao mesmo tempo em que devem respeitar os direitos de trabalhadores e comunidades tradicionais, garantindo a sua viabilidade econômica atual e futura (INMETRO, acesso em junho de 2015).

\subsubsection{Normas ISO}

A ISO é uma organização internacional não governamental com o objetivo de facilitar a coordenação internacional e a unificação de padrões industriais. O objetivo básico da ISO consiste em estabelecer normas técnicas que representem e traduzam o consenso dos diferentes países do mundo. Os representantes dos diversos países discutem, analisam e chegam a um acordo quanto a uma determinada norma (ISO, 2016).

A norma criada pela ISO mais conhecida e utilizada mundialmente é a norma ISO 9.000 que tem como foco principal apoiar qualquer tipo de organização, independentemente do tamanho, do setor de atividade e do produto ou serviço que oferece, na implementação e operação de sistemas de Gestão da Qualidade eficazes (MARTINS, 2010). 
As empresas buscam uma forma de gestão ambiental sustentável para melhoria do desempenho ambiental e redução de riscos trabalhistas e ambientais, utilizando-se das ferramentas e diretrizes da série de normas ABNT NBR ISO 14.000.

A gestão ambiental prioriza a abordagem de Comando e Controle. O "Comando" está baseado na criação de dispositivos e exigências legais e o "Controle" em mecanismos utilizados para garantir o cumprimento do comando, balizando as ações das indústrias para as medidas de combate à poluição e adequação de processos produtivos (ISO 14.001/2004).

A NBR ISO 14.001/2004 especifica requisitos relativos a um Sistema de Gestão Ambiental (SGA), permitindo a uma organização formular uma política e objetivos que levem em conta os aspectos legais e as informações referentes aos impactos ambientais significativos.

Segundo Franchetti (2011), a Norma ISO 14.001/2004 é um bom instrumento de gestão ambiental, pois se comprovou que as taxas de geração de resíduos sólidos são significativamente reduzidas nas empresas que possuem esta certificação. Contudo a norma se aplica aos aspectos ambientais que possam ser controlados pela organização e sobre os quais se presume que ela tenha influência e não prescreve critérios específicos de desempenho ambiental.

Já a NBR ISO 14.031/2002 estabelece diretrizes para um processo de Avaliação do Desempenho Ambiental (ADA) baseada em um processo contínuo de coleta e avaliação de dados que se utiliza de auditoria ambiental para verificar a conformidade de acordo com requisitos definidos classificados em Indicadores de Desempenho Ambiental (IDA) e Indicadores de Condições Ambientais (ICA).

\subsubsection{Avaliação de desempenho}

Fijal (2007), expressa que é necessário desenvolver ferramentas que permitam a análise dos impactos referentes às medidas ecológicas a serem tomadas, substituindo assim as práticas vigentes, principalmente no setor da indústria gráfica.

O Centro Nacional de Tecnologias Limpas (CNTL, 2003), através dos guias de gestão ambiental e manuais práticos de $\mathrm{P}+\mathrm{L}$, recomenda três níveis de avaliação para os 
processos, visando hierarquicamente à minimização ou à reutilização dos resíduos e emissões geradas. Prioriza a avaliação quanto à possibilidade de redução na fonte de consumos de substâncias tóxicas, matérias-primas, insumos, água, energia, gerações de resíduos sólidos, líquidos, efluentes e emissões atmosféricas.

A avaliação também é realizada mediante a postura em favorecer a diminuição dos impactos causados pela extração e deposição de rejeitos da natureza, assume o comprometimento de respeitar a imagem institucional, as relações de trabalho, de socializar o conhecimento, os acordos com o governo, comunidades e grupos ambientalistas (TONDOWSKI, 1998; CAGNIN, 1999).

\subsubsection{Indicadores de desempenho ambiental}

Os indicadores são ferramentas técnico-gerenciais importantes para orientar a tomada de decisão e estabelecer parâmetros comparativos de processos (OLIVEIRA, 2006). Lundberg, Balfors e Folkeson (2009), afirmam que o processo de seleção de indicadores é a consequência natural da fase de coleta e análise de dados visando à melhoria do processo, e para Nagel (2003) os indicadores são ferramentas fundamentais para a realização do desempenho ambiental do programa de $\mathrm{P}+\mathrm{L}$.

A seleção de indicadores ambientais funciona como um método de avaliação do impacto ambiental e também fornece o nível de detalhamento necessário a nível estratégico de gestão (SCAVONE, 2006; GALE, 2006; BURRITT; HERZIG; TADEO, 2009; STANISKIS; STASISKIENE, 2006; TAM et al., 2006).

Para o CNTL (2003) a utilização dos indicadores tem por finalidades principais ilustrar as melhorias ambientais ao longo do tempo, além de detectar as potenciais melhorias no processo produtivo, definindo as metas do desempenho ambiental.

Conforme o CNTL (2003) o uso dos indicadores ambientais tem os seguintes objetivos: 
- Ilustrar melhorias ambientais ao longo do tempo em determinadas avaliações;

- $\quad$ Detectar potenciais para melhorias no processo produtivo;

- Definir objetivos e metas de performance ambiental;

- $\quad$ Monitorar a performance ambiental;

- Identificar oportunidades para produção mais limpa;

- $\quad$ Promover a motivação do público interno;

- Proporcionar uma base para implantação de Sistemas de Gestão Ambiental.

A utilização dos indicadores depende do tipo e das características dos projetos a serem desenvolvidos. Neste sentido o Quadro 1 apresenta exemplos de indicadores representativos.

Quadro 1 - Exemplos de indicadores de processo para avaliação.

\begin{tabular}{|c|c|c|}
\hline INDICADOR & DESCRIÇÃo & UNIDADE \\
\hline Consumo de Papel/Papelão & Valor mensal & $\mathrm{kg}$ \\
\hline Consumo de Tintas & Valor mensal & $\mathrm{kg}$ \\
\hline Consumo de Energia & Valor mensal & $\mathrm{Kwh}$ \\
\hline Consumo de Água & Valor mensal & $\mathrm{m}^{3}$ \\
\hline Total de resíduos sólidos gerados & Valor mensal de geração & $\mathrm{kg}$ \\
\hline Resíduos de Papel/Papelão & Valor mensal de geração & $\mathrm{kg}$ \\
\hline Chapas Metálicas & Valor mensal de geração & $\mathrm{kg}$ \\
\hline Resíduos sólidos não contaminados & Valor mensal de geração & $\mathrm{kg}$ \\
\hline Resíduos sólidos contaminados & Valor mensal de geração & $\mathrm{kg}$ \\
\hline
\end{tabular}

Fonte: Adaptado - CNTL, 2003; ABTG, 2016.

Como destacam Larson e Brown (1997), as variações nas matérias-primas, processos, produtos, resíduos, tamanho da companhia, fornecedores, localização 
física e geográfica e demanda por parte dos consumidores, influenciam o que precisa ser monitorado. O que dificulta é determinar quais indicadores são aplicáveis a uma determinada situação, uma vez que um mesmo indicador pode ser efetivo para uma companhia e não para outra.

A norma ABNT NBR ISO 14.031/2002 prevê duas categorias gerais de indicadores a serem considerados na ADA: os Indicadores de Condição Ambiental (ICA) e os Indicadores de Desempenho Ambiental (IDA).

De acordo com a norma supracitada, são divididos em dois grupos:

- $\quad$ Os Indicadores de Desempenho de Gestão (IDG), que fornecem informações sobre as práticas de gestão que influenciam no desempenho ambiental.

- $\quad$ Os Indicadores de Desempenho Operacional (IDO), que fornecem informações sobre as operações do processo produtivo que interferem no desempenho ambiental.

Uma ampla revisão dos instrumentos e métodos disponíveis para a Avaliação do Desempenho Ambiental veio a mostrar que todos deixam a critério das empresas a definição do que poderia representar, para elas, um caminho adequado ao autoconhecimento e à comunicação dos resultados (FRANK e GROTHE-SENF, 2006). Dessa forma,

[...] como não existem parâmetros especificados, o resultado da avaliação do desempenho ambiental não esclarece muito em termos de um nível "bom" ou "ruim" para o ambiente global e na comparação com resultados de outras empresas. O desempenho é medido pelo grau de alcance dos próprios objetivos, não sendo, portanto, comparável (FRANK e GROTHE-SENF, 2006).

\subsection{PRODUÇÃO MAIS LIMPA (P+L)}

A Organização das Nações Unidas (ONU), difunde a $\mathrm{P}+\mathrm{L}$ através do programa UNEP - United Nation for Environment Programme, sendo apoiada no Brasil pela CETESB

- Companhia Ambiental do Estado de São Paulo e também pelo CNTL - Centro Nacional de Tecnologias Limpas (CNTL, 2003). 
A Produção Mais Limpa $(\mathrm{P}+\mathrm{L})$ refere-se a uma aplicação contínua e integrada de uma estratégia ambiental, econômica e tecnológica junto ao processo industrial com objetivo de aumentar a eficiência no uso de recursos, insumos e redução da geração de resíduos sólidos (CEBDS, 2015).

Segundo Massote e Santi (2013), Silva e outros (2013), para que a $P+L$ possa ser entendida como instrumento de gestão ambiental, considera-se como premissas desta metodologia ações como:

- Reduzir ou eliminar a poluição durante o processo de produção;

- Reduzir ou eliminar desperdícios durante processo de produção (entendendo que poluição é matéria-prima mal aproveitada);

- Incorporar a ideia de melhoria continua;

- $\quad$ Exigir mudança de atitude ao longo da hierarquia da empresa;

- Estimular a criatividade e inovação;

- Permitir identificar oportunidades de negócios através da valorização de resíduos antes de seu descarte.

De acordo com Rossi (2008), Barbieri (2007), UNEP (2016), as ações de adoção da metodologia $\mathrm{P}+\mathrm{L}$ em um processo industrial agrega benefícios, como por exemplo:

- Melhoria da imagem da empresa;

- Minimização e mitigação dos impactos ambientais gerados pela produção;

- Melhoria organizacional e da qualidade do trabalho;

- $\quad$ Aumento da ecoeficiência produtiva;

- $\quad$ Atendimento legal;

- Vantagem competitiva;

- Redução de custos, economia financeira e aumento dos lucros. 
A $P+L$ faz parte das novas estratégias de administração industrial e propõe o uso de conceitos industriais que aumentam a eficiência e previnem a poluição na fonte, reduzindo ou evitando riscos para a população humana, em especial, e o ambiente em geral (SCHENINI, 2005). Lopes Silva e outros (2013) destacam que a $\mathrm{P}+\mathrm{L}$ apresenta uma abordagem integrada e sistêmica à gestão, já que inclui mudanças em todos os aspectos organizacionais relacionados à produção e aos processos, e sua definição reflete a uma busca por melhoria contínua.

Rossi e Barata (2009) apontam que a $P+L$ deve ser encarada como uma estratégia de atuação que se estende desde a revisão do design dos produtos, da origem dos materiais e consumo de energia, até a análise dos impactos na utilização de matériasprimas, na sua disposição e no descarte das sobras.

Segundo Furtado e outros (1998), a Produção Mais Limpa introduz medidas de redução e minimização que previnem os efeitos adversos provocados pelos efluentes e resíduos gerados. A empresa que começa a se preocupar com questões ambientais e começa a usufruir de um processo de "melhoria contínua" que propicia o surgimento de inovação em todos os sentidos (processo, produto e gerencial).

A P+L é extremamente ampla e o termo pode incluir aspectos que afetam a saúde e segurança do trabalhador, e também melhoria na seleção de matérias-primas, uso racional de insumos, controle de emissão de poluentes no ar, água e solo incluindo resíduos sólidos, bem como o impacto ambiental dos produtos durante seu ciclo de vida (ALMEIDA et al., 2013). Baseia-se em metodologia de auditoria de geração de resíduos sólidos e efluentes que evolui por meio de ferramentas de avaliação de fluxos de material e de energia nos processos produtivos, fluxograma, balanço de material e energia até a identificação, avaliação e implantação de oportunidades de $\mathrm{P}+\mathrm{L}$, de caráter preventivo visando a eliminação ou redução (em quantidade e/ou grau de toxicidade) da geração de resíduos e efluentes e, consequentemente, de diminuição do fluxo de entrada de matérias-primas e insumos (MASSOTE; SANTI, 2013).

O princípio básico da metodologia de Produção Mais Limpa $(\mathrm{P}+\mathrm{L})$ é eliminar a poluição durante o processo de produção, não no final. A razão: todos os resíduos que a empresa gera custaram-Ihe dinheiro, pois foram comprados a preço de matéria-prima e consumiram insumos como água e energia. Uma vez gerados, continuam a consumir dinheiro, seja sob a forma de gastos de tratamento e armazenamento, seja 
sob a forma de multas pela falta desses cuidados, ou ainda pelos danos à imagem e à reputação da empresa (PMAISL, 2017).

A utilização da metodologia $\mathrm{P}+\mathrm{L}$ desenvolve um novo comportamento produtivo, proativo, aproveitando, ao máximo, matérias-primas e insumos utilizados nos processos, evitando a geração dos resíduos durante a produção, sendo a ênfase focada na observação. Desta forma, há o mapeamento das atividades produtivas e o olhar rígido sobre a sua operacionalidade, visando à detecção de oportunidades de melhorias (TERRA; WASSERMAN, 2013).

Hicks e Dietmar (2007) destacam a sensibilização dos funcionários está diretamente relacionada com a divulgação de informações para a organização com o intuito de aumentar seus benefícios ambientais, econômicos e organizacionais. Isso representa despertar nos colaboradores o sentimento de pertencimento e com isso a dedicação e a preocupação com o bem estar organizacional, o que corrobora com Terra e Wasserman (2013) quanto a influência da $P+L$ na cultura organizacional da empresa. A sensibilização dos funcionários, de acordo com Kjaerheim (2005), atua como um mecanismo que visa complementar as informações necessárias para o estabelecimento das ações de $\mathrm{P}+\mathrm{L}$. As reuniões constantes entre os representantes dos funcionários e a direção trazem progresso ao processo de implementação e otimização da abordagem, com resolução de problemas e minimização dos erros.

Desta forma, a $\mathrm{P}+\mathrm{L}$ é uma ferramenta poderosa nas questões de ecoeficiência, na redução de perdas, redução da utilização de insumos e geração de resíduos, que contribuem significativamente com a sustentabilidade ambiental e econômica (MASSOTE; SANTI, 2013; SILVA et al., 2013).

\subsubsection{Exemplos de resultados alcançados com a implantação da $P+L$}

A aplicação da $\mathrm{P}+\mathrm{L}$ em uma indústria gráfica possibilitou enfatizar, avaliar, procedimentar os fatores críticos, caracterizados pelos benefícios "Atendimento à legislação", "Melhorias das condições relativas à Saúde e Segurança Ocupacional", "Redução do consumo de matérias-primas e recursos naturais" e "Redução da geração de resíduos". As diversas reduções no processo industrial geraram ganhos 
ambientais, sociais e econômicos para a gráfica, garantindo a sustentabilidade industrial (TERRA; WASSERMAN, 2013).

A P+L implantada em uma indústria de cerâmica proporcionou a redução de 4,3\% no consumo de energia, 22,33\% do consumo de água, e $8 \%$ na emissão de dióxido de carbono, assim maior rentabilidade financeira (HUANG; JEWN; BIN, 2013, apud OLIVEIRA; GUARDIA, 2015).

Nesse mesmo segmento industrial foi possível registrar a redução do uso de carvão em 2,2\%, uso de água em 1,53\% e diminuição de resíduos em 3,1\%, além de grande redução no uso de outros insumos quando o gerenciamento ambiental foi combinado com a metodologia da P+L (ZHI-DONG et al., 2011, p. 205-206).

Zeng e outros (2010) ao avaliar o impacto da Produção Mais Limpa e sua performance em empresas de distintos segmentos produtivos, encontrou um impacto positivo global no desempenho ambiental e também que a produção mais limpa em atividades de menor custo apresenta benefícios significativos em pouco tempo, ainda que a implantação da $\mathrm{P}+\mathrm{L}$ em atividades de menor custo não requer esforço financeiro significativo, contudo os benefícios financeiros são imediatos.

\subsection{RESÍDUOS SÓLIDOS}

O Incremento significativo de resíduos descarregados no meio ambiente ocorreu a partir de meados do século XX, onde são iniciadas sequências de eventos/acidentes ambientais que começam a chamar a atenção da sociedade para a crescente degradação da qualidade ambiental, e, também, para o fato de que a qualidade de vida do homem e mesmo sua sobrevivência, em longo prazo, no planeta está por ela condicionada (SEIFFERT, 2007).

A industrialização e expansão social época, não apresentava a geração de resíduos sólidos como um problema significativo, pois a população era pequena e a quantidade de áreas disponíveis para a sua assimilação era grande. Os problemas com os resíduos passam a ser perceptíveis quando iniciaram a centralização em tribos, aldeias e cidades. O aglomerado e a necessidade de desenvolvimento social 
promovem a produção e acumulação elevada de resíduos (TCHOBANOGLOUS; THEISEN; VIGIL, 1993).

A geração de resíduos sólidos, além de ser diretamente relacionada ao crescimento demográfico e industrial, também é função de fatores socioeconômicos (produto interno bruto - PIB, educação, ocupação, renda familiar, número de membros na família, entre outros), da diversificação de bens e serviços e da intensificação do consumo (AIDIS, 2006; KHAN; KUMAR; SAMADDER, 2016).

Estima-se que a população mundial, que gira em torno de 6 bilhões de habitantes, esteja gerando 3,5 milhões de toneladas de resíduos sólidos por dia, em 2025 é esperado que a geração atinja 6 milhões de toneladas por dia (IFC, 2014).

Song, Li e Zeng (2015) afirmam que os resíduos simbolizam a ineficiência de qualquer sociedade moderna e representam recursos mal utilizados.

\subsubsection{Identificação e classificação dos resíduos sólidos}

De acordo com a Resolução CONAMA n 313/2002, resíduo sólido industrial é todo resíduo que resulte de atividades industriais e que se encontre nos estados sólido, semissólido, gasoso - quando contido, e líquido - cujas particularidades tornem inviável o seu lançamento na rede pública de esgoto ou em corpos d'água, ou exijam para isso soluções técnicas ou economicamente inviáveis em face da melhor tecnologia disponível.

O alto grau de heterogeneidade dos resíduos sólidos permite que sejam atribuídas diversas classificações, conforme o tipo de enfoque que interessa considerar relativo à possibilidade de tratamento ou a seu destino (BARROS, 2012).

Rocca (1993) considera a classificação em função das suas propriedades físicas, químicas ou infectocontagiosas e com base na identificação de contaminantes presentes em sua massa. Desta forma é fundamental o conhecimento prévio do processo industrial, a fim de identificar as substâncias presentes e a verificação de sua periculosidade. 
Devido à grande variedade de resíduos sólidos existentes, fez-se necessária sua classificação agrupando os resíduos com características afins, de forma a tornar mais fácil a sua gestão e seu gerenciamento.

Pela definição do Art. 19 ${ }^{\circ}$ inciso X, da Política Estadual de Resíduos Sólidos (PERS), instituída pela Lei n 9.264/09, entende-se por resíduos sólidos:

[...] resíduos no estado sólido e semissólido, que resultam de atividades de origem doméstica, comercial, industrial, agrícola, de serviços da área da saúde, inclusive os de limpeza pública; ficam incluídos nesta definição os lodos provenientes de sistema de tratamento de água e esgoto e da drenagem pluvial, aqueles gerados em equipamentos e instalações de controle de população, bem como determinados líquidos cujas particularidades tornem inviável o seu lançamento na rede pública de esgoto ou corpos d'água, ou exijam para isto soluções técnicas e economicamente inviáveis em face à melhor tecnologia disponível.

Pela definição do Art. $3^{\circ}$, inciso XVI, da PNRS, entende-se por resíduos sólidos:

[...] material, substância, objeto ou bem descartado resultante de atividades humanas em sociedade, a cuja destinação final se procede, se propõe proceder ou se está obrigado a proceder, nos estados sólido ou semissólido, bem como gases contidos em recipientes e líquidos cujas particularidades tornem inviável o seu lançamento na rede pública de esgotos ou em corpos d'água, ou exijam para isso soluções técnica ou economicamente inviáveis em face da melhor tecnologia disponível.

Já a Associação Brasileira de Normas Técnicas (ABNT), a partir da norma técnica NBR 10.004/2004, define resíduos sólidos como:

[...] todo resíduo nos estados sólido e semissólido resultam de atividades de origem industrial, doméstica, hospitalar, comercial, agrícola, de serviços e de varrição. Ficam incluídos nesta definição os lodos provenientes de sistemas de tratamento de água, aqueles gerados em equipamentos e instalações de controle de poluição, bem como determinados líquidos cujas particularidades tornem inviável o seu lançamento na rede pública de esgotos ou corpos de água, ou exijam, para isso, soluções técnicas e economicamente inviáveis em face à melhor tecnologia disponível.

Em função do grau de periculosidade dos resíduos a ABNT 10.004/1004 propõe a seguinte classificação:

- Resíduo Classe I (perigoso): São resíduos que apresentam risco a saúde pública e/ou ao meio ambiente, ou ainda que constem no anexo A ou B da NBR 
10.004/2004. Suas características são: inflamabilidade, corrosividade, reatividade, toxicidade e patogenicidade.

- Resíduo Classe II (não perigoso), divididos em duas categorias:

- Resíduo Classe II A (não-inertes): São aqueles que não se enquadram como o resíduo classe I ou classe II B. Podem apresentar propriedades tais como: combustibilidade, biodegradabilidade ou solubilidade em água.

- Resíduo Classe II B (inertes): São aqueles resíduos que submetidos a um contato dinâmico e estático com água destilada ou deionizada, à temperatura ambiente não apresentarem nenhum de seus constituintes solubilizados a concentrações superiores aos padrões de potabilidade de água, excetuando-se aspecto, cor, turbidez, dureza e sabor.

Para auxiliar nesse processo de classificação, a própria NBR sugere um fluxo a ser observado no processo de geração, apresentado na Figura 1. 
Figura 1 - Fluxograma de classificação e caracterização de resíduos sólidos

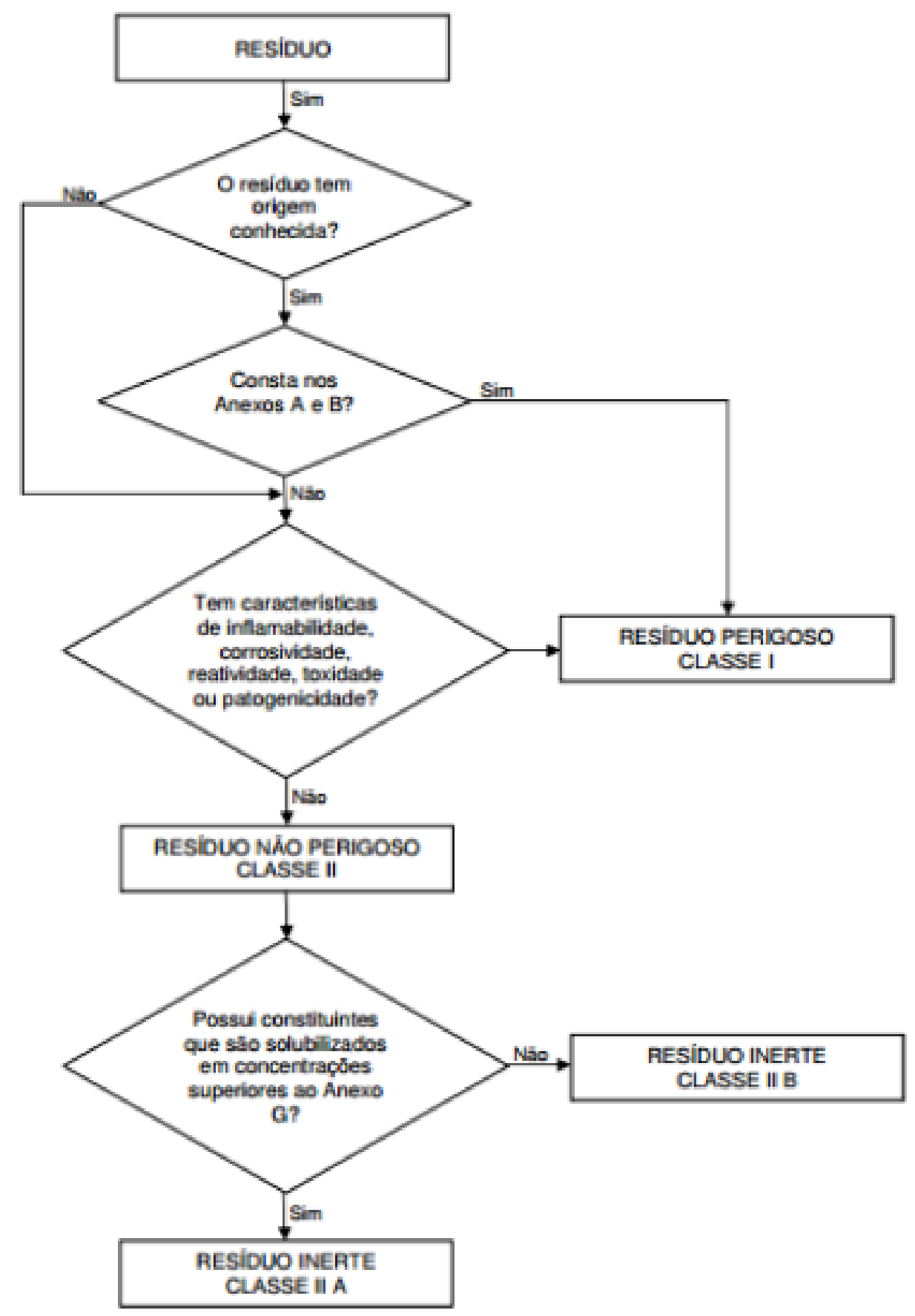

Fonte: ABNT NBR 10.004/04. 
A Política Nacional de Resíduos Sólidos (PNRS) ainda agrupa os resíduos sólidos em onze classes:

- Resíduos domiciliares: são os resíduos gerados em casas, apartamentos e condomínios, provenientes de atividades diárias;

- Resíduos de limpeza urbana: são os resíduos presentes nos logradouros públicos, originários da varrição e outros serviços de limpeza;

- Resíduos sólidos urbanos: que englobam os dois tópicos anteriores;

- Resíduos de estabelecimentos comerciais e prestadores de serviços: são os resíduos gerados em estabelecimentos comerciais;

- Resíduos dos serviços públicos de saneamento básico: são os resíduos gerados nessas atividades, com exceção dos resíduos sólidos urbanos;

- Resíduos industriais: são resíduos gerados em indústrias e seu processo produtivo;

- Resíduos de serviços de saúde: são os resíduos gerados em serviços de saúde, de acordo com Sistema Nacional do Meio Ambiente (SISNAMA) e Sistema Nacional de Vigilância Sanitária (SNVS);

- Resíduos de construção civil: são todos os resíduos gerados em construções, reformas, demolições, reparos e também os provenientes de escavação para preparação do terreno;

- Resíduos agrossilvopastoris: são os resíduos gerados nas atividades agropecuárias e silviculturais;

- Resíduos de serviços de transportes: são os resíduos gerados em portos, aeroportos, terminais alfandegários, rodoviários, ferroviários e de fronteiras;

- Resíduos de mineração: são os resíduos gerados nas atividades de mineração, desde pesquisas, extração ou beneficiamento. 


\subsection{GERENCIAMENTO DE RESÍDUOS SÓLIDOS}

O mapeamento do processo e identificação das fontes de geração de resíduos pode fornecer o suporte necessário para obtenção de informações, como a massa e a energia que entram e saem dos processos, levando em conta quais os impactos destas atividades ao meio ambiente. Assim, pode-se estabelecer o controle das variáveis envolvidas, possibilitando a escolha da estratégia mais adequada para a redução da geração de resíduos (ALVES; OLIVEIRA, 2007; FAGNANI; GUIMARÃES, 2017).

Considerando a necessidade de definir procedimentos mínimos para o gerenciamento de resíduos, com vistas a preservar a saúde pública e a qualidade do meio ambiente, a Resolução do Conselho Nacional de Meio Ambiente (CONAMA) de 5 de agosto de 1993 dispõe sobre o gerenciamento de resíduos sólidos gerados nos portos, aeroportos, terminais ferroviários e rodoviários, no Art. $1^{\circ}$. II definiu-se pela primeira vez no Brasil o conceito de Programa de Gerenciamento de Resíduos Sólidos (PGRS) como sendo:

[...] o documento integrante do processo de licenciamento ambiental, que aponta e descreve as ações relativas ao manejo de resíduos sólidos gerados nos portos, aeroportos, terminais ferroviários e rodoviários, contemplando os aspectos referentes à geração, segregação, acondicionamento, coleta, armazenamento, transporte, tratamento e disposição final, bem como a proteção à saúde pública (CONSELHO NACIONAL DO MEIO AMBIENTE, 1993, p. 592).

O gerenciamento adequado dos resíduos sólidos não depende apenas de tecnologia, recursos humanos ou financeiros, mas de noções de planejamento e controle, da conduta empresarial adotada e disseminada pelos dirigentes por meio da gestão institucional, determinada pela combinação de dois fatores: atitude (valores) e comportamento (ações e omissões) (PRICEWATERHOUSECOOPERS, 2006; SILVA, 2008).

Segundo Singh, Brueckner e Pardhy (2015), o gerenciamento de resíduos implica numa combinação de técnicas de prevenção, melhorias de qualidade e iniciativas de reciclagem que servem para reduzir a quantidade de resíduos produzidos. Entretanto, este deve ser entendido como um sistema composto pela interação de diversas 
etapas e processos internos das industrias, as quais devem assegurar o controle sobre a geração, a coleta, a transferência, o transporte e disposição final de resíduos (TCHOBANOGLOUS et al., 1993; ZURBRÜGG et al., 2012).

Segundo a CETESB (2005), deve-se buscar inicialmente no gerenciamento dos resíduos sólidos, a redução da utilização de recursos, sendo que isto inclui qualquer prática ambientalmente segura, de redução na fonte, reuso reciclagem e recuperação de materiais e do conteúdo energético dos resíduos, visando reduzir a quantidade ou volume dos mesmos a serem tratados e, posteriormente, adequadamente dispostos. Isso é possível seguindo as cinco etapas: segregação, acondicionamento, armazenamento, coleta e transporte, destinação.

O gerenciamento de resíduos sólidos engloba as etapas de identificação da fonte geradora, segregação, acondicionamento, armazenamento, coleta, transporte e destinação final ambientalmente adequada, devendo-se considerar, de acordo com a PNRS, a ordem de prioridade: não geração, redução, reutilização, reciclagem, tratamento e disposição final.

\subsubsection{Segregação}

De acordo com a NBR 12.235/1992 a mistura de resíduos sólidos incompatíveis pode causar: geração de calor, fogo ou explosão, geração de fumos e gases tóxicos, geração de gases inflamáveis, solubilização de substâncias tóxicas, dentre outros.

A correta segregação além de evitar a mistura de resíduos sólidos incompatíveis contribui com a preservação do estado destes, com objetivo de um melhor tratamento como destinação, podendo retornar a cadeia produtiva para fabricação de novos produtos, e também se tornar fonte de renda com sua venda.

Os resíduos sólidos devidamente segregados podem ser considerados matéria-prima para fabricação de novos produtos e como oportunidade para rentabilidade.

Com objetivo de padronizar a segregação e evitar mistura e contaminação entre resíduos sólidos, a Resolução CONAMA n 275/2001 estabelece o código de cores para a segregação de resíduos sólidos, sendo eles:

- $\quad$ Azul - Papel/Papelão; 
- $\quad$ Vermelho - Plástico;

- $\quad$ Verde - Vidro;

- $\quad$ Amarelo - Metal;

- $\quad$ Preto - Madeira;

- $\quad$ Laranja - Resíduos Perigosos;

- $\quad$ Branco - Resíduos Ambulatoriais;

- $\quad$ Roxo - Resíduos radioativos;

- $\quad$ Marrom - Resíduos orgânicos;

- $\quad$ Cinza - Resíduo Comum, não reciclável e não passível de segregação.

\subsubsection{Acondicionamento}

De acordo com Rocca e outros (1993), os recipientes a serem utilizados para o acondicionamento de resíduos sólidos devem ser construídos com material compatível a cada tipo específico de resíduo. Contudo, seja qual for o tipo de acondicionador, são requeridas as seguintes propriedades:

- $\quad$ Estanqueidade;

- $\quad$ Capacidade de contenção dos resíduos em seu interior;

- $\quad$ Resistência física a pequenos choques;

- Durabilidade;

- Compatibilidade com o equipamento de transporte, em termos de forma, volume e peso.

A escolha do tipo de acondicionador mais adequado para um específico caso dependerá basicamente das características do resíduo, do tipo de transporte a ser utilizado e das quantidades a serem armazenadas.

\subsubsection{Armazenamento}


O armazenamento de resíduos sólidos consiste em um sistema de contenção temporária à espera de destinação, reciclagem/recuperação, tratamento ou disposição final adequada.

São estabelecias as condições para armazenamento, segundo as normas:

- $\quad$ NBR 12.235/1992 - Armazenamento de resíduos perigosos, fixa as condições exigíveis para o armazenamento de resíduos sólidos perigosos de forma a proteger a saúde pública e o meio ambiente;

- $\quad$ NBR 11.174/1990 - Armazenamento de resíduos não inertes e inertes, fixa as condições exigíveis para obtenção das condições mínimas necessárias ao armazenamento de resíduos classes II, de forma a proteger a saúde pública e o meio ambiente.

\subsubsection{Coleta e transporte}

A NBR 13.221/2000 dispõe sobre o transporte terrestre de resíduos e apresenta os requisitos gerais para esta atividade, sendo respectivamente:

- $\quad$ O transporte deve ser feito por meio de equipamentos adequados, obedecendo às regulamentações pertinentes;

- $\quad$ O estado de conservação do equipamento de transporte deve ser tal que, durante o transporte, não permita o vazamento ou derramamento do resíduo;

- Os resíduos, durante o transporte, devem estar protegidos de intempéries, assim como devem estar devidamente acondicionados;

- Os resíduos não podem ser transportados juntamente com alimentos, medicamentos, produtos destinados ao uso e/ou consumo humano ou animal ou com embalagens destinadas a estes fins;

- O transporte de resíduos deve atender à legislação ambiental específica, quando existente, bem como deve ser acompanhado de documento de controle 
ambiental previsto pelo órgão competente, devendo informar o tipo de acondicionamento.

\subsubsection{Destinação final}

A destinação de resíduos sólidos para tratamento/disposição deve ser considerada quando já esgotada todas as possibilidades e reaproveitamento e reciclagem interna. A escolha da destinação e o tipo de tratamento a ser aplicado deve ser realizada em função das características dos resíduos sólidos e os aspectos relacionados às tecnologias aplicáveis para tratamento, aspectos ambientais, econômicos e sociais. De acordo com o Art. $3^{\circ}$ da Lei 12.305 (PNRS) define-se:

Destinação final ambientalmente adequada: destinação de resíduos que inclui a reutilização, a reciclagem, a compostagem, a recuperação e o aproveitamento energético ou outras destinações admitidas pelos órgãos competentes do SISNAMA, do SNVS e do SUASA;

Disposição final ambientalmente adequada: distribuição ordenada de rejeitos em aterros, observando normas operacionais específicas de modo a evitar danos ou riscos à saúde pública e à segurança e a minimizar os impactos ambientais adversos; Reciclagem: processo de transformação dos resíduos sólidos que envolve a alteração de suas propriedades físicas, físico-químicas ou biológicas, com vistas à transformação em insumos ou novos produtos, observadas as condições e os padrões estabelecidos pelos órgãos competentes.

\subsection{PROGRAMA DE GERENCIAMENTO DE RESÍDUOS SÓLIDOS}

\subsubsection{Coleta de dados}


Lee e Koh (2002) afirmam que o levantamento de dados é um dos passos principais para a implementação do programa de $\mathrm{P}+\mathrm{L}$. Leva em conta a coleta da maior quantidade de dados possível que auxiliem na caracterização do processo, produto ou serviço. Abrange desde o acondicionamento de matérias-primas e os insumos posteriores (água, energia, componentes secundários, entre outros) até os resíduos sólidos gerados.

O registro eficiente e interpretação dos dados relativos às atividades de uma instalação, incluindo informações de emissões potenciais de interesse é melhor depurado quanto maiores forem os parâmetros de medida (KOLOMINSKAS; SULIVAN, 2004). Isso proporciona meios para o monitoramento das iniciativas de $\mathrm{P}+\mathrm{L}$ e contribui para um processo de coleta de dados eficiente.

De acordo com a ABTG (2016), os dados que servem para alimentar os indicadores de desempenho operacional e podem ser coletados a partir de monitoramento e medição, registros de inventário e de produção, registros financeiros e contábeis, registros de compras, entre outros.

\subsubsection{Diagnóstico do gerenciamento de resíduos sólidos}

Na realização do diagnóstico para implementação do PGRS podem ser encontradas inúmeras barreiras tais como: resistência a mudanças na rotina, problemas gerados por aumento de demanda ou falhas no processo industrial, desmotivação, falta de recursos financeiros para o diagnóstico, falta de organização e registro de informações na empresa, limitações de tempo para elaboração do programa, etc.

O diagnóstico com enfoque na $\mathrm{A} \mathrm{P}+\mathrm{L}$ explora o processo produtivo e as demais atividades de uma empresa e avalia a utilização de materiais e energia. A partir disso, são criteriosamente examinados os produtos, as tecnologias e os materiais, com a intenção de diminuir os resíduos, as emissões e os efluentes, e descobrir modos de reutilizar os resíduos inevitáveis (CNTL, 2002). 


\subsubsection{Caracterização do PGRS}

O Programa de Gerenciamento de Resíduos Sólidos atua como um mecanismo fiscalizador da adesão das empresas às diretrizes da Política Nacional de Resíduos Sólidos, bem como instrumento de planejamento visando ações ecoeficientes.

As ações que integram um PGRS são definidas a partir da identificação de suas fontes geradoras, da caracterização e classificação dos resíduos, do levantamento dos riscos associados eles, tudo em consonância com a Política Nacional de Resíduos Sólidos e atendendo a critérios sanitários, econômicos, ambientais, sociais e legais.

O PGRS é um dos documentos para se obter sucesso no manejo dos resíduos sólidos, pois é baseado nos princípios da não geração e minimização da geração, apontando ações de como devem ser feitos a segregação, acondicionamento, armazenamento, transporte e disposição final dos resíduos (MEDEIROS, 2002).

A combinação dos atores envolvidos na geração de resíduos e gestão de processo é crucial para o sucesso do gerenciamento de resíduos. Como evidenciado pela literatura, é importante ter um contexto que desencadeia a sinergia das ações e suas colaborações (COSTA; FERRÃO, 2010).

Portanto, a concepção de um modelo de gerenciamento de resíduos sólidos apropriado para o empreendimento constitui de um conjunto de critérios e procedimentos que fundamentam a gestão adequada em todo seu processo, desde a geração até a destinação final.

\subsubsection{Monitoramento e medição}

O monitoramento é o acompanhamento sistemático do processo, a fim de fornecer as informações registradas, não só de quantificação mas, e principalmente de comparação com os dados anteriores para avaliar a eficácia das melhorias implantadas. 
As informações obtidas no monitoramento permitem a avaliação do desempenho do programa, apontando ineficiências e desvios, apontados como oportunidades de melhoria.

O instrumento de medição deve ser aferido e calibrado, com padrões dimensionais adequados, sendo aplicável à realidade do estudo balança portátil.

\subsection{LEGISLAÇÕES E NORMAS GERAIS APLICÁVEIS}

As normas legais, no âmbito federal, estadual e municipal, relacionadas ao Programa de Gerenciamento de Resíduos Sólidos, são apresentadas nas seções a seguir.

\subsubsection{Legislação federal}

LEI № 6.938, de 31/08/1981 - Regulamentada pelo Decreto n 99.274/90, que dispõe sobre a Política Nacional do Meio Ambiente, seus fins e mecanismos de formulação e aplicação e dá outras providências. Determina que a Política Nacional do Meio Ambiente tem por objetivo a preservação, melhoria e recuperação de qualidade ambiental propícia à vida, visando assegurar, no País, condições ao desenvolvimento socioeconômico e proteção da dignidade da vida humana, atendidos, dentre outros, os princípios de manutenção da qualidade ambiental, de controle das atividades potencial ou efetivamente poluidoras, de recuperação de áreas degradadas, de proteção de áreas ameaçadas de degradação e de educação ambiental.

A LEI NN 6.938 ainda estabelece que a Política Nacional do Meio Ambiente visa, dentre outros objetivos, a compatibilização do desenvolvimento econômico-social com a preservação da qualidade ambiental, a difusão de tecnologias de manejo do meio ambiente, a divulgação de dados e informações ambientais, a formação de uma consciência pública voltada para a conservação da qualidade ambiental e do equilíbrio ecológico e a imposição, ao poluidor e predador, da obrigação de recuperar e/ou indenizar os danos ambientais causados.

LEI No 9.605, de 12/02/1998 dispõe sobre as Sanções Penais e Administrativas Derivadas de Condutas e Atividades Lesivas ao Meio Ambiente, e dá outras 
providências, estabelece no Art. 60, pena de detenção, de um a seis meses, ou multa, ou ambas as penas cumulativamente para quem construir, reformar, ampliar, instalar ou fazer funcionar, em qualquer parte do território nacional, estabelecimentos, obras ou serviços potencialmente poluidores, sem licença ou autorização dos órgãos ambientais competentes, ou contrariando as normas legais e regulamentares pertinentes.

LEI No 9.795, de 27/04/1999 - Dispõe sobre a educação ambiental, institui a Política Nacional de Educação Ambiental e dá outras providências. De acordo com a lei, entende-se por educação ambiental os processos por meio dos quais o indivíduo e a coletividade constroem valores sociais, conhecimentos, habilidades, atitudes e competências voltadas para a conservação do meio ambiente, bem de uso comum do povo, essencial à sadia qualidade de vida e sua sustentabilidade.

LEI No 12.305, de 02/08/2010 - Institui a Política Nacional de Resíduos Sólidos, dispondo sobre seus princípios, objetivos e instrumentos, bem como sobre as diretrizes relativas à gestão integrada e ao gerenciamento de resíduos sólidos, incluindo os perigosos, às responsabilidades dos geradores e do poder público e aos instrumentos econômicos aplicáveis.

\subsubsection{Resoluções CONAMA}

RESOLUÇÃO CONAMA № 275, de 25/04/2001 - Dispõe sobre a Padronização de Cores para a Coleta Seletiva.

RESOLUÇÃO CONAMA No 307, de 05/07/2002 - Estabelece diretrizes, critérios e procedimentos para a gestão dos resíduos da construção civil. Alterada pela Resolução no 348/04 (alterado o inciso IV do art. $3^{\circ}$ ), Resolução no 431/11 (alterados os incisos II e III do art. $3^{\circ}$ ) e pela Resolução no 448/12 (art. $2^{\circ}, 4^{\circ}, 5^{\circ}, 6^{\circ}, 8^{\circ}, 9^{\circ}, 10$ e 11).

RESOLUÇÃO CONAMA No 313, de 29/10/2002 - Dispõe sobre o Inventário Nacional de Resíduos Sólidos Industriais. 


\subsubsection{Legislação estadual}

LEI No 3.582, de 03/11/1983 - Dispõe sobre Medidas de Proteção, Conservação e Melhoria do Meio Ambiente no Estado do Espírito Santo.

LEI No 4.126, de 22/07/1988 - Dispõe sobre a Política Estadual de Proteção, Conservação e Melhoria de Meio Ambiente e sua implantação através do Sistema Estadual de Meio Ambiente.

LEI No 4.701, de 08/12/1992 - Dispõe sobre a Política Estadual de Meio Ambiente, o Patrimônio Ambiental, o Controle Ambiental, a Tutela Ambiental e Medidas para a Promoção de Melhoria Ambiental.

LEI No 6.834, de 25/10/2001 - Dispõe sobre a Responsabilidade da Destinação de Lâmpadas Usadas e dá outras providências.

LEI No 9.264, de 16/07/2009 - Institui a Política Estadual de Resíduos Sólidos e define princípios, fundamentos, objetivos, diretrizes e instrumentos para a Gestão Integrada, Compartilhada e Participativa de Resíduos Sólidos, com vistas à redução, ao reaproveitamento e ao gerenciamento adequado dos resíduos sólidos; à prevenção e ao controle da poluição; à proteção e à recuperação da qualidade do meio ambiente e à promoção da saúde pública, assegurando o uso adequado dos recursos ambientais no estado do Espírito Santo, a promoção do Eco negócio e a Produção Mais Limpa.

\subsubsection{Decretos estaduais}

DECRETO No 3.513-N, de 23/04/1993 - Regulamenta a Fiscalização Ambiental e as Sanções e Penalidades estabelecidas pela Lei n 4.701 de 08/12/1992.

DECRETO N².299, de 09/06/1986 - Regulamenta a Lei N³.582/83 que dispõe sobre as medidas de proteção, conservação e melhoria de Meio Ambiente no estado do Espírito Santo. 


\subsubsection{Legislação municipal}

LEI No 4.999, DE 15/10/2010 - Institui o Código Municipal do Meio Ambiente, dispõe sobre a política de Meio Ambiente e sobre o Sistema Municipal do Meio Ambiente para o Município de Vila Velha.

LEI $N^{\circ} 2.915$, DE 25/01/1994 - institui em Vila Velha - Espírito Santo o código municipal de limpeza urbana.

LEI N 5.617 , DE 13/05/2015 - altera a redação da lei municipal no. 2.915, de 25 de janeiro de 1994, quanto à responsabilidade dos Geradores de resíduos e ao valor das multas Aplicáveis às infrações cometidas na destinação e disposição final dos resíduos.

\subsubsection{Decretos municipais}

DECRETO N 086/2011 - Regulamenta o Capítulo III - Licenciamento Ambiental - Do Livro II, da Lei n 4.999, de 20.10.2010, que "Institui o Código Municipal do Meio Ambiente, dispõe sobre a política de Meio Ambiente e sobre o Sistema Municipal do Meio Ambiente para o Município de Vila Velha".

DECRETO No 025/2014 - Altera o Caput e o $\S 1^{\circ}$ do Art. 48 do Decreto nº 086/2011, de 24.03.2011, que regulamenta o Capítulo III - Do Licenciamento Ambiental.

Livro II, da Lei n 4.999, de 20.10.2010, que "Institui o Código Municipal do Meio Ambiente, que dispõe sobre a Política de Meio Ambiente e sobre o Sistema Municipal do Meio Ambiente para o Município de Vila Velha" e altera os Anexos I e II do Decreto n. ${ }^{\circ}$ 159/2013 de 20.08.2013, para promover a adequação necessária aos termos da Resolução. 
DECRETO No 172, DE 06/10/2015 - Regulamenta, na forma do art. 57-a, da lei municipal no. 2.915/1994, com alterações decorrentes da lei municipal nº 5.617/2015, a obrigatoriedade de acondicionamento, coleta, remoção, transporte, tratamento, destinação e disposição final ambientalmente adequada dos resíduos e rejeitos provenientes dos grandes geradores e dos geradores de resíduo de natureza especial, e dá outras providências.

DECRETO No 15, DE 27/01/2016 - Altera o disposto no decreto municipal no. 172, de 06 de outubro de 2015, que discorre acerca da obrigatoriedade de acondicionamento, coleta, remoção, transporte, tratamento, destinação e disposição final ambientalmente adequada dos resíduos e rejeitos provenientes dos grandes geradores de resíduos e dos geradores de resíduo de natureza especial.

\subsubsection{Normas técnicas ABNT}

As normas regulamentam determinado procedimento ou processo como forma de regulamentar, padronizar critérios para que não ocorram conflitos procedimentais.

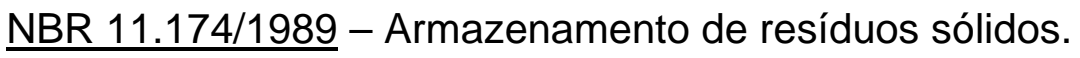

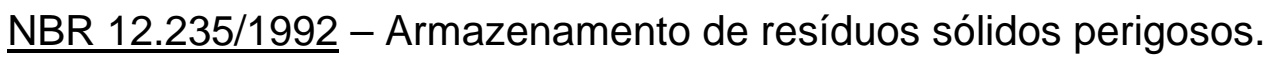

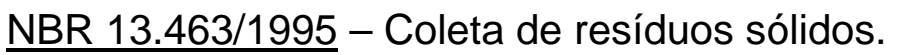

NBR 10.004/2004 - Resíduos sólidos - classificação.

NBR 10.005/2004 - Lixiviação de resíduos - procedimento.

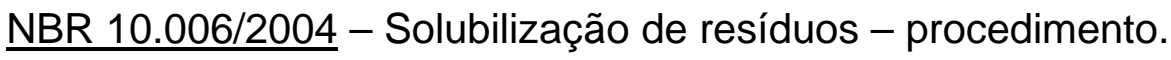

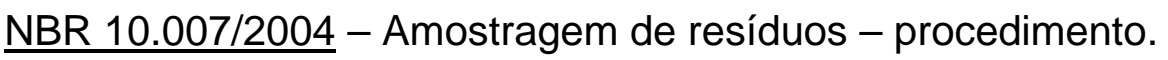




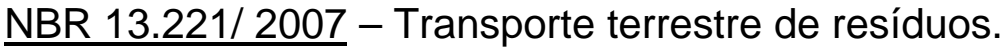

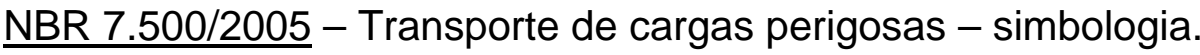

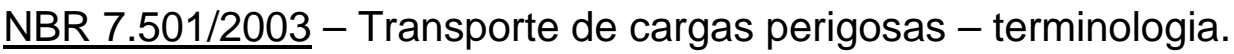

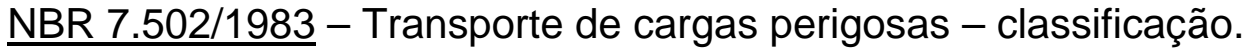

NBR 7.503/2005 - Fichas de emergência para o transporte de cargas perigosas.

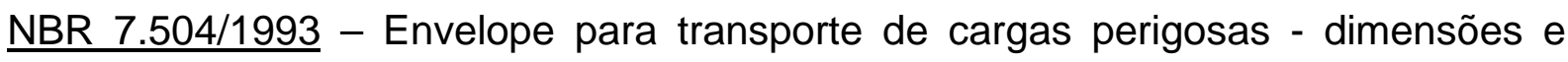
utilizações. 
A pesquisa se caracterizou como exploratória por meio de um estudo de caso, como guia para o desenvolvimento de procedimentos com finalidade de obter novas descobertas, esclarecer decisões e descrever na prática distintos aspectos da gráfica em estudo (VERGARA, 2000; GIL, 2008; YIN, 2009).

Foi realizado a caracterização da indústria gráfica e o diagnóstico do gerenciamento de resíduos sólidos, este sob enfoque das premissas da metodologia de $\mathrm{P}+\mathrm{L}$, com observação direta intensiva do processo industrial, o que fundamentou a elaboração do PGRS, sua implementação e monitoramento num período total de 7 meses, tendose a análise quantitativa de geração de resíduos sólidos como parâmetro de referência para avaliação do desempenho das ações implementadas e melhorias alcançadas.

O estudo de caso foi dividido em quatro etapas: 1- coleta de dados para caracterização e diagnose do empreendimento; 2- diagnóstico do gerenciamento de resíduos sólidos com enfoque em P+L; 3- implementação do PGRS na indústria gráfica VV; 4avaliação de desempenho da implementação do PGRS.

\subsection{COLETA DE DADOS PARA CARACTERIZAÇÃO E DIAGNOSE DO EMPREENDIMENTO}

Dentre a literatura consultada, como ISO 14.031/2002, ferramentas de análise de gestão ambiental e indicadores definidos por Matuchevski (2007) e guias do CNTL, elaborou-se formulários para coleta de dados desta pesquisa, disponíveis nos APÊNDICES A, B, C, D.

A diagnose das informações gerais do empreendimento foi realizada por meio da descrição e porte do empreendimento, principais produtos produzidos, produtos com produção contínua (volumes) e do gerenciamento de resíduos sólidos com enfoque em $\mathrm{P}+\mathrm{L}$ foi realizada mediante observações diretas, entrevistas não estruturadas, semiestruturadas e ações participativas com olhar rígido sobre os aspectos ambientais e operacionalidade da indústria (identificação das áreas e atividades desenvolvidas, fonte de geração de resíduos sólidos, identificação, quantitativo de geração, logística de acondicionamento e armazenamento; logística de transporte 
(interno/externo) e de destinação final, através da aplicação dos questionários disponíveis nos APÊNDICES A, B e C.

Com o propósito de obter parâmetros comparativos relacionados à produção industrial e de modo a caracterizar uma confiabilidade nos dados quantitativos, definiu-se no diagnóstico as matérias-primas (MP) como sendo papel e tintas, e quanto aos resíduos sólidos, devido ao alto grau de heterogeneidade, associou-se os tipos diversos de resíduos sólidos gerados conforme sua classificação (NBR 10.004/2004), definidos como resíduos sólidos não contaminados (RS-NC), resíduos sólidos diversos contaminados (RS-DC), resíduos sólidos recicláveis, estes divididos entre resíduos de papel/papelão e resíduos de chapas metálicas.

\subsubsection{Levantamento dos equipamentos e sistema de impressão}

Os sistemas para impressão utilizados na Gráfica VV são: CTP (Computer to Plate), ou seja, do computador para impressão digital e a impressão offset.

São utilizados os sistemas de impressão offset da marca Heidelberg, fabricante alemão de equipamentos de precisão para a indústria de mídia impressa e também sistemas para impressão digital. O Quadro 2 apresenta os equipamentos utilizados na produção da Gráfica VV, relacionando sua capacidade de produção e unidade de medida, sendo também relacionado às Figuras 2 a 11.

Quadro 2 - Equipamentos do processo industrial

\begin{tabular}{|c|c|c|c|c|c|}
\hline Equipamentos & $\begin{array}{c}\text { Quanti } \\
\text { dade }\end{array}$ & $\begin{array}{c}\text { Volume de } \\
\text { Produção }\end{array}$ & $\begin{array}{c}\text { Unidade } \\
\text { de } \\
\text { medida }\end{array}$ & $\begin{array}{c}\text { Produção } \\
\text { média } \\
\text { diária }\end{array}$ & Figura no \\
\hline Impressora digital & 2 & 3.000 & Fls/hora & 12.000 & 2 \\
\hline Copiadora & 2 & 8.000 & Fls/hora & 32.000 & 3 \\
\hline $\begin{array}{c}\text { Processadora de chapa } \\
\text { Impressora offset 4 } \\
\text { cores }\end{array}$ & 1 & 30 & Chp/hora & 16 & 4 \\
\hline $\begin{array}{c}\text { Impressora offset 2 } \\
\text { cores }\end{array}$ & 1 & 6.000 & Fls/hora & 36.000 & 6 \\
\hline Dobradeira & 1 & 6.000 & Fls/hora & 42.000 & 7 \\
\hline
\end{tabular}




\begin{tabular}{|c|c|c|l|c|c|}
\hline Guilhotina & 1 & 3.600 & Fls/hora & 21.600 & 8 \\
\hline $\begin{array}{c}\text { Montagem - Corte e } \\
\text { vinco manual }\end{array}$ & 1 & 60 & Fls/hora & 420 & 9 \\
\hline Encadernadora & 2 & 80 & Vol/hora & 60 & 10 \\
\hline Embaladora & 1 & 120 & Vol/hora & 600 & 11 \\
\hline
\end{tabular}

Legenda: Qtd de eqpts - Quantidade de equipamentos, Fls/hora - Quantidade de folhas por hora, Vol/hora - Volume por hora, Chp/hora - Chapas Metálicas por hora.

Fonte: $\mathrm{O}$ autor.

Figura 2 - Representação da Impressora digital, Figura 3 - Representação da Copiadoras, presente na gráfica VV

presentes na gráfica $\mathrm{VV}$

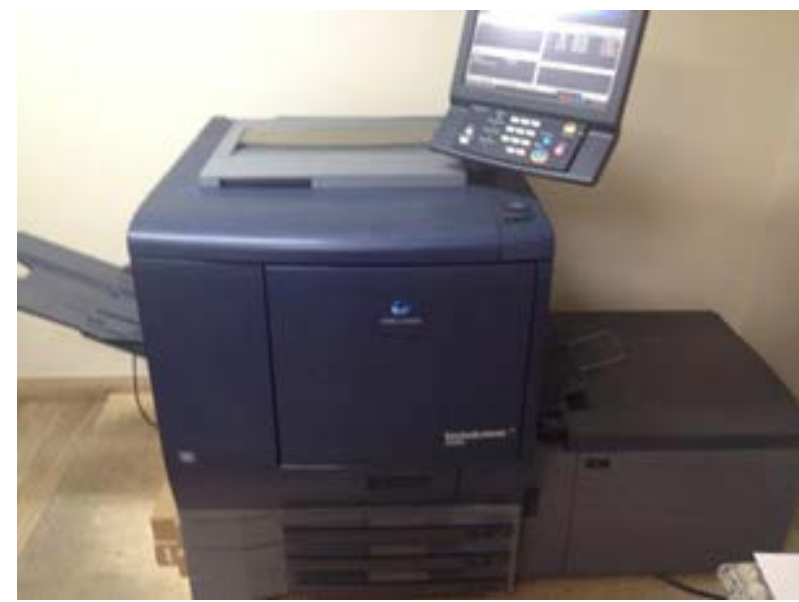

Fonte: $\mathrm{O}$ autor.

Figura 4 - Representação da Processadora de chapas, presente na gráfica $\mathrm{VV}$

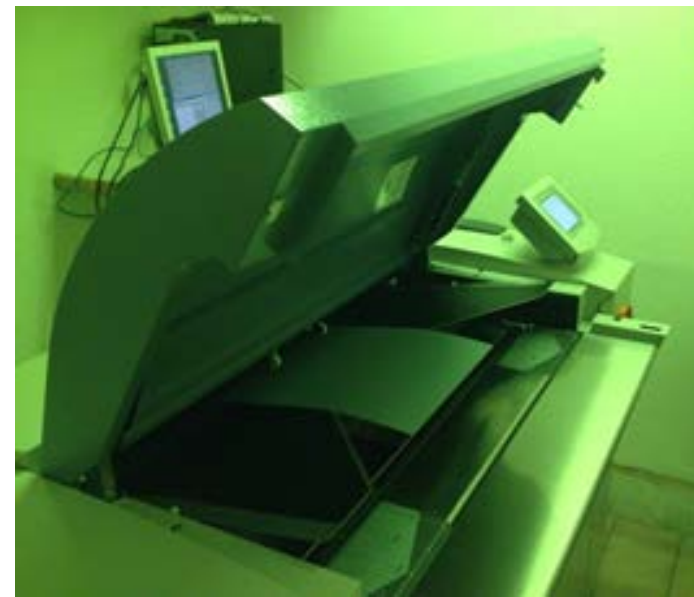

Fonte: O autor.

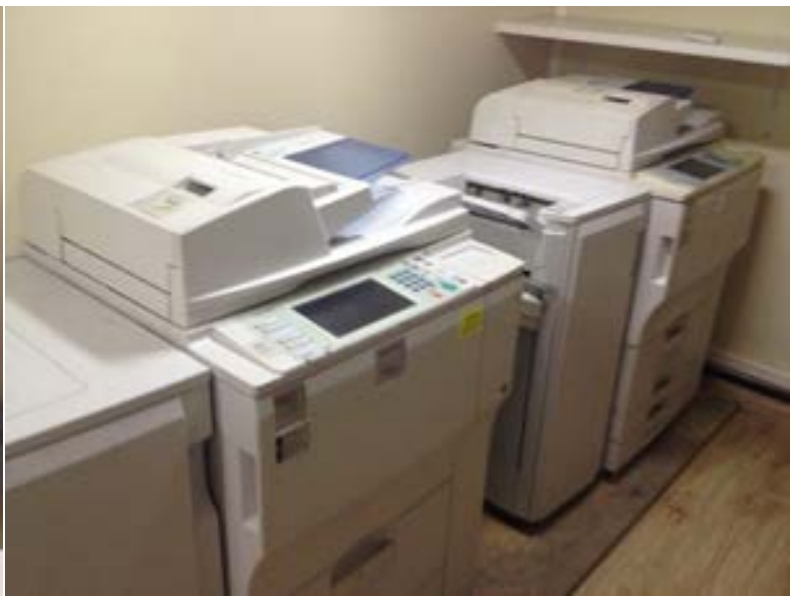

Fonte: O autor.

Figura 5 - Representação da Impressora Offset 4 cores, presente na gráfica $\mathrm{VV}$

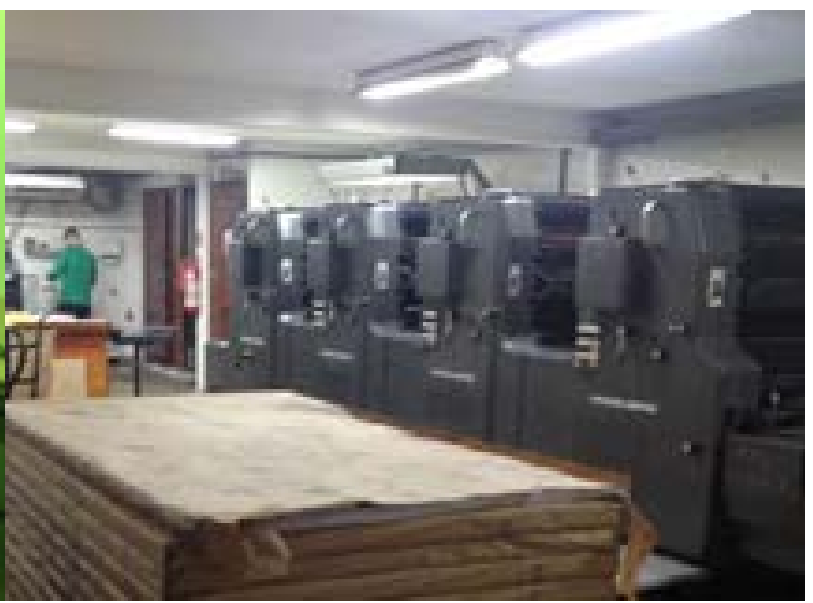

Fonte: O autor. 
Figura 6 - Representação da Impressora Offset 2 Figura 7 - Representação da Dobradeira cores presente na gráfica $\mathrm{V} V$ presente na gráfica $\mathrm{VV}$

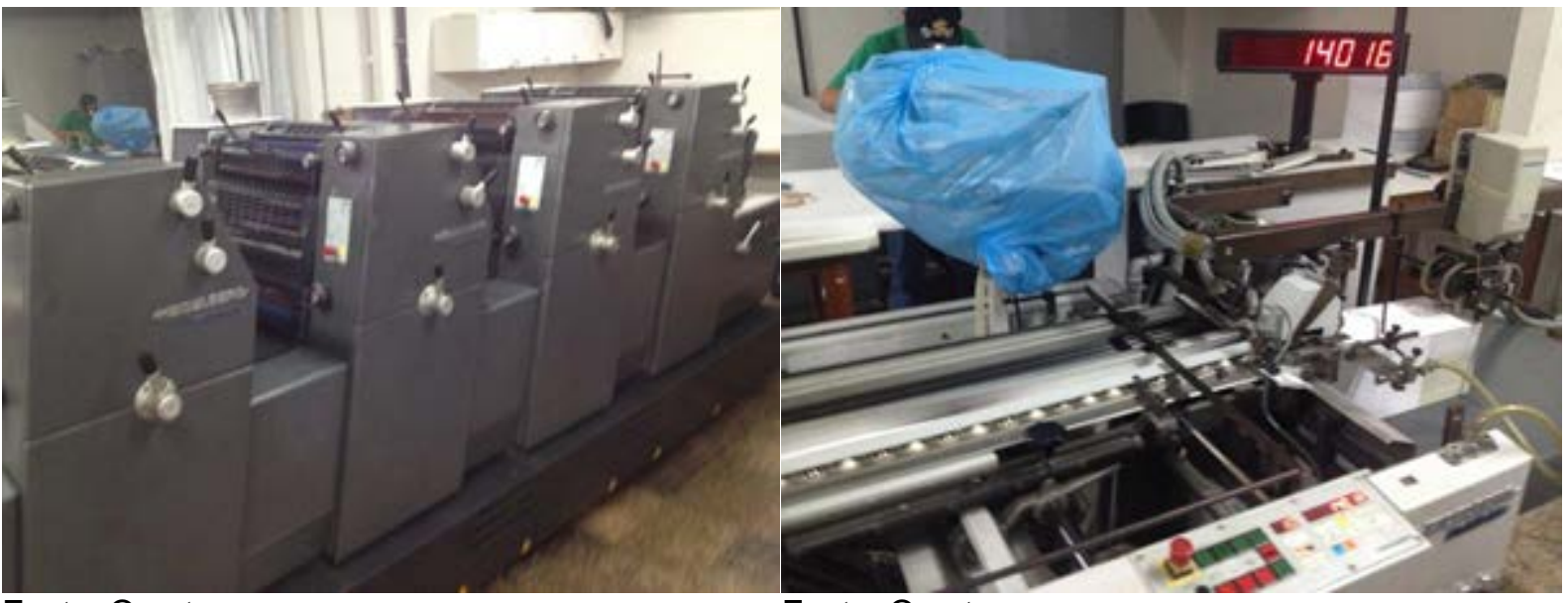

Fonte: $\mathrm{O}$ autor.

Fonte: $\mathrm{O}$ autor.

Figura 8 - Representação da Guilhotina, presente Figura 9 - Representação da Montagem, na gráfica $\mathrm{VV}$ presente na gráfica $\mathrm{VV}$

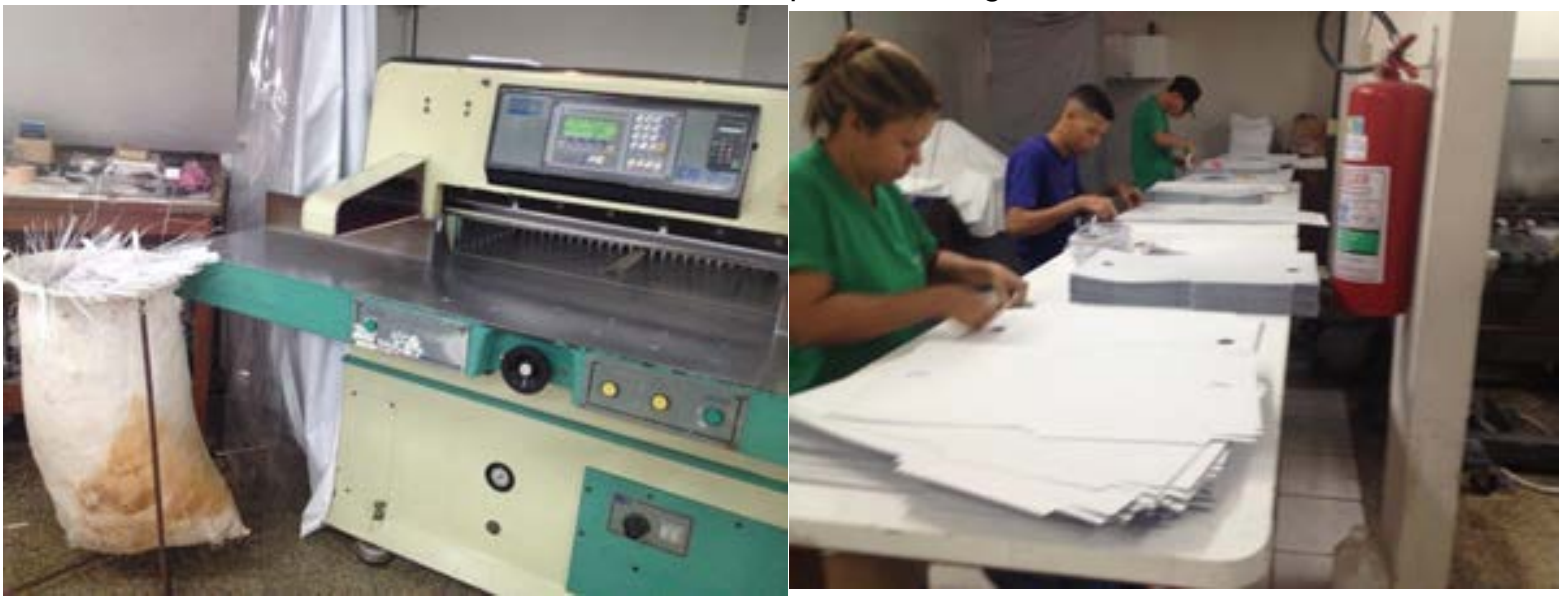

Fonte: $\mathrm{O}$ autor.

Fonte: $\mathrm{O}$ autor.

Figura 10 - Representação da Encadernadora, Figura 11 - Representação da Embaladora, presente na gráfica $\mathrm{VV}$

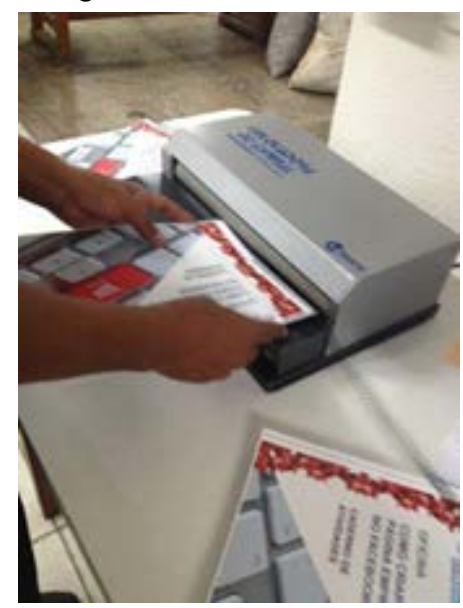

Fonte: O autor. presente na gráfica $\mathrm{V} V$

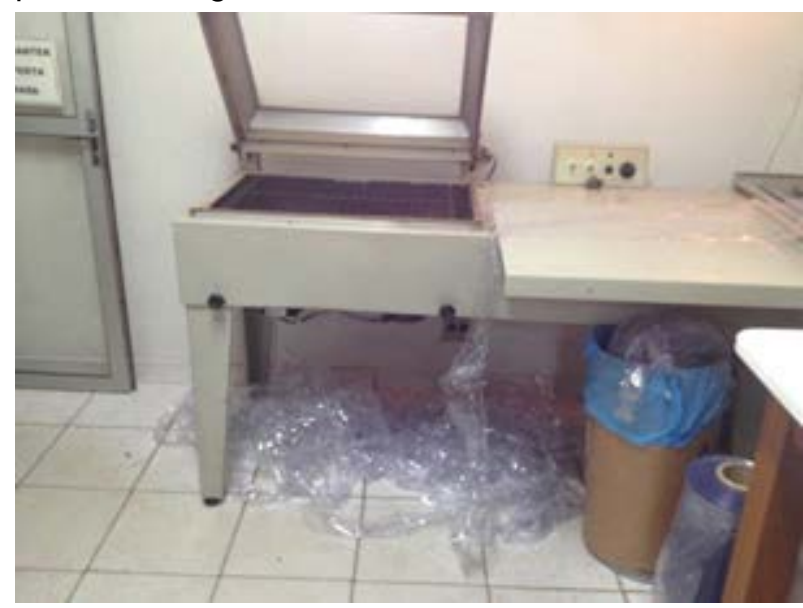

Fonte: O autor. 


\subsubsection{Descrição do processo produtivo}

De modo a detalhar as etapas de pré-impressão, impressão e pós-impressão do o processo produtivo da Gráfica VV, são descritos abaixo as etapas e representado na Figura 12.

Pré-impressão: A imagem é enviada para gravação da matriz de impressão, onde cada cor de impressão é gerada e são gravadas as chapas de impressão, feitas de zinco, que recebem um tratamento fotográfico. Após a gravação é executada uma prova (peça unitária do produto desenhado) para conferência e liberação pelo design, sendo realizada a montagem da chapa na impressora Offset.

Nesta etapa há o emprego de diferentes produtos, como: reveladores, fixadores, solventes, tecidos, recipientes, embalagens, papel, etc., gerando volume considerável de resíduos sólidos.

Impressão: As máquinas de impressão são abastecidas com as tintas e o papel, que são conduzidos por cilindros e um sistema pneumático. A tinta é transferida para os cilindros de borracha, denominados de blanquetas. É regulada a máquina de impressão (calibragem de cor) e as cores sobrepostas conferidas na mira de análise. Nesta etapa há geração de resíduos sólidos de papel e plástico usados, aparas e carcaças de adesivos, resíduos de tintas/verniz, blanquetas contaminadas, filtros, embalagens, trapos, estopas, etc.

Pós-impressão: Após a impressão, o produto vai para o setor de dobra, corte e montagem, onde o produto passa por corte nas marcações de inspeção (miras), dobra e são montados (separados por lotes). Os impressos são analisados, conferidos com os arquivos digitais e submetidos à análise de qualidade. 
Figura 12 - Fluxograma do processo industrial praticado na Gráfica VV

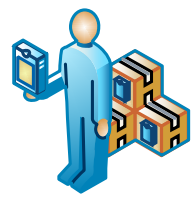

Pré-impressão

$\downarrow$
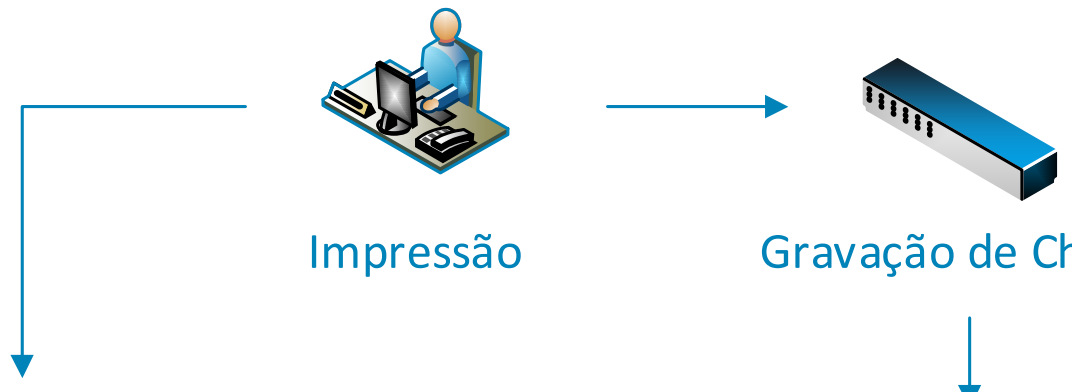

Impressão

Gravação de Chapa

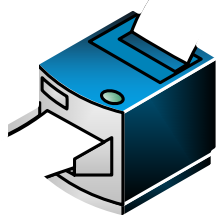

Impressão Digital
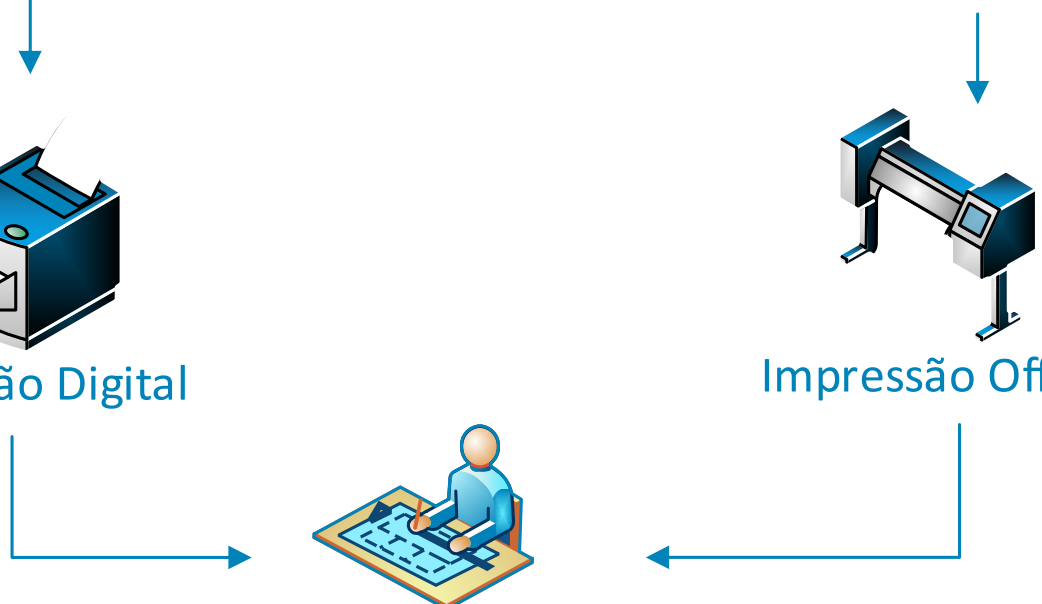

Impressão Offset

Pós-impressão
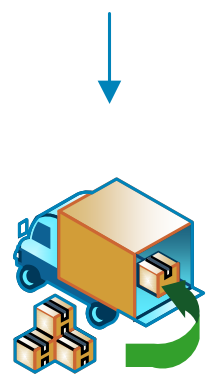

Expedição

Fonte: O autor. 


\subsection{DIAGNÓSTICO DO GERENCIAMENTO DE RESÍDUOS SÓLIDOS}

O diagnóstico começa pela identificação e caracterização do empreendimento e segue, sobre as premissas de $\mathrm{P}+\mathrm{L}$, com foco no gerenciamento de resíduos sólidos, recorrendo a diferentes fontes de informações na gráfica, proporcionando a real visão das atividades, avaliação das melhores práticas operacionais e oportunidades de melhoria.

Considerando a legislação aplicável e normas vigentes, realizou-se a análise de cada etapa do gerenciamento de resíduo sólidos, sendo registrada as informações nos formulários de pesquisa (APÊNDICES).

Ressalta-se a coleta de dados e registros se deram através de entrevista aberta e também semiestruturada, seguindo direcionamento do APÊNDICE C, promovendo o diagnóstico de situação das áreas geradoras de RS, sendo registrado as necessidades de melhoria e também identificadas as oportunidades de melhoria contínua e interação entre processos/setores da Gráfica VV.

\subsubsection{Geração dos resíduos sólidos}

O levantamento da geração de resíduos sólidos procedeu-se através da verificação in loco, acompanhado pelo responsável da área em estudo, com observações diretas e entrevistas não estruturadas com os colaboradores e operadores, de forma a constatar e identificar as fontes de geração de resíduos sólidos, aspectos ambientais das áreas geradoras e potenciais de melhoria quanto a interligação de processos.

\subsubsection{Identificação e classificação}

A identificação dos resíduos sólidos foi realizada de acordo com o acompanhamento do processo industrial e/ou da atividade geradora. A classificação e identificação de resíduos sólidos segue as premissas do fluxograma sugerido pela ABNT 10.004/2004. 


\subsubsection{Acondicionamento e armazenamento}

Para verificação das etapas de acondicionamento e armazenamento considerou-se as diretrizes das normas ABNT NBR 11.174/1990 e NBR 12.235/1992.

\subsubsection{Quantificação}

A quantificação de resíduos sólidos gerados no processo produtivo foi executada pelo facilitador, colaborador treinado e multiplicador dos conceitos de $\mathrm{P}+\mathrm{L}$, utilizando-se balança portátil com capacidade de até $50 \mathrm{~kg}$ para pesagem dos acondicionadores e registro das informações em formulário (APÊNDICE D).

De modo a evitar desvios quanto ao registro das informações, o monitoramento, identificação e quantificação foi centralizada em colaborador permanente, visando uma padronização da coleta de dados e demais ações de registro do processo participativo.

\subsubsection{Coleta e transporte}

Para a coleta e transporte foram analisados os documentos referentes às empresas prestadoras de serviços de gerenciamento de resíduos sólidos, observando-se atendimento à NBR 13.463/1995, NBR 13.221/2007, NBR 7.500/2005, NBR $7.503 / 2005,7.504 / 1993$.

\subsubsection{Destinação final}

Para a destinação final foram analisados os documentos referentes às empresas prestadoras de serviço utilizadas, buscando-se oportunidades de destinação final ambientalmente correta conforme prioridades da PNRS. 


\subsection{IMPLEMENTAÇÃO DO PGRS}

A elaboração do PGRS exclusivo ao empreendimento possibilitou a reunião de esforços para instrumentalização dos conceitos e dos objetivos da $\mathrm{P}+\mathrm{L}$, objetivando a implementação de ações mediante adoção das oportunidades de melhoria levantados no diagnóstico, enfatizando valores ecoeficientes e uma mudança na rotina operacional e cultura organizacional.

Desta forma, a implementação do PGRS desenvolveu-se como um processo interativo, observações diretas e proximidade junto aos funcionários da gráfica, com revisão contínua dos processos executados, análise de sugestões e observações de oportunidades de melhoria registro das informações quali-quantitativas do gerenciamento de resíduos sólidos.

A implementação contou com fontes diversas do local de origem das informações, observações diretas com discussão e levantamento de novas possibilidades de fluxo de processo, compartilhamento de informações sobre os processos internos, e envolvimento para implementação participativa, com estabelecimento de ações e responsabilidades para os geradores (funcionário responsável pelo setor/equipamento) de resíduos sólidos e interfaces (geração compartilhada entre setores), apresentados no Quadro 3.

\subsubsection{Monitoramento}

Visando assegurar o cumprimento das ações ecoeficientes implementadas, procedeuse com o monitoramento e controle das ações, análise dos dados e informações registradas, garantindo também os critérios previstos e consistência das informações registradas.

O monitoramento e acompanhamento diário foi executado pelo funcionário designado como facilitador, também responsável pelo registro dos dados quantitativos. 
Quadro 3 - Atividades do processo participativo do gerenciamento de RS com enfoque na P+L na Gráfica VV.

\begin{tabular}{|c|c|c|c|c|}
\hline & Ação & Metodologia & Objetivo & Resultados \\
\hline 1 & $\begin{array}{l}\text { Descrição das atividades e fluxo do } \\
\text { processo da área }\end{array}$ & $\begin{array}{l}\text { Preenchimento } \\
\text { formulário }\end{array}$ & $\begin{array}{lll}\text { Fornecer } & \text { informações } & \text { da } \\
\text { atividade e } & \text { posicionamento } & \text { no } \\
\text { fluxograma } & & \end{array}$ & $\begin{array}{l}\text { Elaboração do fluxograma e descrição } \\
\text { de cada uma das atividades }\end{array}$ \\
\hline 2 & $\begin{array}{l}\text { Relação de matérias-primas e insumos - } \\
\text { de entrada na etapa do processo em } \\
\text { análise de materiais de saída }\end{array}$ & $\begin{array}{l}\text { Preenchimento } \\
\text { formulário }\end{array}$ & $\begin{array}{l}\text { Registrar as entradas e saídas } \\
\text { dos processos }\end{array}$ & $\begin{array}{l}\text { Obtenção das informações } \\
\text { quantitativas de entrada e saída, com } \\
\text { identificação das fontes geradoras de } \\
\text { resíduos sólidos }\end{array}$ \\
\hline 3 & $\begin{array}{l}\text { Observação das oportunidades de } \\
\text { melhoria e evolução do processo }\end{array}$ & $\begin{array}{l}\text { Preenchimento de } \\
\text { formulário, entrevista } \\
\text { aberta não dirigida }\end{array}$ & $\begin{array}{l}\text { Registrar as oportunidades de } \\
\text { melhoria para tomada de ações e } \\
\text { evolução }\end{array}$ & \begin{tabular}{|lrr} 
Obtenção da & \multicolumn{1}{c}{ relação } & das \\
oportunidades e adequação & de \\
procedimentos, identificação & da \\
cultura organizacional e sinergia entre & \\
processos & & \\
\end{tabular} \\
\hline 4 & $\begin{array}{l}\text { Monitoramento dos resíduos sólidos } \\
\text { segregados na fonte e acondicionados }\end{array}$ & $\begin{array}{l}\text { Preenchimento } \\
\text { formulário }\end{array}$ & $\begin{array}{l}\text { Obter registro do quantitativo de } \\
\text { resíduos sólidos gerados e } \\
\text { informações diversas. }\end{array}$ & $\begin{array}{l}\text { Registro do quantitativo de resíduos } \\
\text { gerados e do seu acondicionamento }\end{array}$ \\
\hline 5 & $\begin{array}{l}\text { Realização do manejo e transporte dos } \\
\text { resíduos sólidos para local específico de } \\
\text { armazenamento temporário }\end{array}$ & $\begin{array}{l}\text { Manejo dos resíduos } \\
\text { até a área de apoio e } \\
\text { armazenamento } \\
\text { temporário }\end{array}$ & $\begin{array}{l}\text { Dispor os resíduos sólidos } \\
\text { segregados } \\
\text { armazenamento temporário e } \\
\text { posterior destinação final }\end{array}$ & $\begin{array}{l}\text { Melhoramento do aspecto } \\
\text { organizacional do processo produtivo, } \\
\text { segregação dos tipos de resíduos } \\
\text { sólidos de melhor maneira para } \\
\text { manejo }\end{array}$ \\
\hline 6 & $\begin{array}{l}\text { Identificação da experiência, resultados, } \\
\text { dificuldades, avaliação sobre a } \\
\text { implementação do PGRS }\end{array}$ & $\begin{array}{l}\text { Preenchimento } \\
\text { formulário }\end{array}$ & $\begin{array}{l}\text { Identificar o envolvimento e } \\
\text { dificuldades dos facilitadores em } \\
\text { relação à área de atuação e } \\
\text { ações do PGRS. }\end{array}$ & $\begin{array}{l}\text { Identificação dos fatores facilitadores } \\
\text { e das dificuldades estabelecidas } \\
\text { durante o processo produtivo e da } \\
\text { organização }\end{array}$ \\
\hline
\end{tabular}

Fonte: O autor. 


\subsection{AVALIAÇÃO DE DESEMPENHO DA IMPLEMENTAÇÃO DO PGRS}

A avaliação de desempenho ambiental da implementação do PGRS na Gráfica WV foi baseada em indicadores pré-estabelecidos, possibilitando analisar o processo operacional e devida avaliação da evolução do desempenho ambiental durante o período deste estudo.

\subsubsection{Indicadores de desempenho ambiental}

De acordo com CNTL (2003) e ABTG (2016) são trabalhados indicadores que forneçam um nível de detalhamento necessário para monitorar a performance ambiental.

Considerando o processo contínuo de coleta e avaliação de dados pelo diagnóstico do gerenciamento de resíduos sólidos com enfoque em $\mathrm{P}+\mathrm{L}$, adotou-se conforme diretrizes da NBR ISO 14.031/2002 o Indicador de Desempenho Operacional (IDO). Com índices relativos à produção, o IDO proposto e plicado fornece informações sobre as operações do processo produtivo que interferem no desempenho ambiental, e que possibilitou a coleta de dados de modo eficiente e monitoramento das ações de implementação, com adoção de parâmetros comparativos voltados ao gerenciamento de resíduos sólidos de modo a caracterizar uma confiabilidade nos dados registrados.

Dentre os indicadores de desempenho operacional, têm-se:

- Indicador da geração de resíduos sólidos por matéria-prima;

- Indicador do tipo de destinação final ambientalmente adequada;

- Indicador de ecoeficiência quanto ao consumo de matérias-primas e insumos.

6.4.1.1 Indicador da geração de RS por matéria-prima consumida

Os valores de geração mensal para cada tipo de resíduo sólido visa estabelecer o relacionamento causal de ecoeficiência do processo industrial, servindo de parâmetro comparativo de desempenho ambiental quanto ao consumo de matérias-primas. 
O cálculo do indicador de desempenho ambiental da empresa quanto à geração de resíduos sólidos industriais considera a relação entre a massa dos insumos utilizados e a massa dos resíduos sólidos gerados no mês.

Métrica: Este indicador estabelece a razão entre o RS gerado e o consumo de matéria-prima mensal, permitindo analisar o potencial de redução da geração quanto à otimização da produção.

Composição do indicador: [(tipo de resíduos sólido gerado no mês / total de matérias-primas consumidas no mês).100].

\subsubsection{Indicador do tipo de destinação ambientalmente adequada}

O indicador permitiu a verificação da efetiva destinação dada aos resíduos sólidos gerados durante o período monitorado.

Métrica: Este indicador utiliza o valor total do tipo de resíduo sólidos gerado no mês (de acordo com a classificação ABNT 10.004) em razão do total de resíduos sólidos gerados, permitindo analisar a fração de encaminhamento dada a determinado tratamento/destinação final.

Composição do indicador: [(classe de resíduos sólidos gerados no mês / total de matérias-primas consumidas no mês).100].

\subsubsection{Indicador de ecoeficiência}

Este indicador permitiu verificar a evolução da condição ambiental na redução do uso de matérias-primas, energia elétrica e água durante a implementação do PGRS.

Métrica: Para indicar a ecoeficiência e melhoria do processo industrial, estabeleceuse como parâmetro padrão o valor da média de consumo total do período monitorado em razão valor de consumo mensal de matéria-prima e insumos.

Composição do indicador: [(consumo mensal / média de consumo do período).100]. 
7 RESULTADOS E DISCUSSÃO

\subsection{CARACTERIZAÇÃO DA INDÚSTRIA GRÁFICA VV}

\subsubsection{Informações gerais}

A gráfica possui 38 funcionários diretos e funcionamento de 08:00 às 18:00 horas, sendo que a atividade de produção industrial pode variar de acordo com a demanda de serviço, chegando eventualmente a turnos de funcionamento de 24 horas.

O volume da produção Gráfica VV foi mensurado de acordo com a aquisição de papel para impressão offset e tintas (matérias-primas), sendo a informação disponibilizada pelo empreendedor através do controle interno de compras (notas fiscais), apresentando consumo médio mensal de 220 toneladas de papel e 100 toneladas de tintas.

Apresenta receita anual aproximada de 3,6 milhões de reais, sendo enquadrada como uma empresa de pequeno porte de acordo com a classificação do Banco Nacional de Desenvolvimento Econômico e Social (BNDES, acesso em junho, 2015).

O Quadro 4 apresenta em síntese a caracterização da Indústria Gráfica VV.

Quadro 4 - Caracterização do empreendimento

\begin{tabular}{|l|c|}
\hline \multicolumn{2}{|c|}{ Informações Gerais } \\
\hline Localização & Vila Velha - ES \\
\hline Porte & Pequeno porte \\
\hline Receita Anual & 3,6 milhões de reais \\
\hline Consumo médio mensal de Matéria-Prima & 320 toneladas \\
\hline Funcionários diretos & 38 \\
\hline \multicolumn{2}{|c|}{ Informações sobre Gestão Ambiental } \\
\hline Possui licença ambiental? & Sim \\
\hline Possui sistema de gestão ambiental? & Não \\
\hline Possui certificações? & Não \\
\hline Há medição/controle de desempenho ambiental? &
\end{tabular}

Fonte: O autor. 


\subsubsection{Sistema de Gestão}

O controle administrativo e qualidade de processo são realizados por cada responsável pelos setores de produção, assim como a alta direção, avaliando os produtos e validando os requisitos mínimos de qualidade do empreendimento, contudo não há monitoramento sobre a geração de resíduos sólidos, inventário de resíduos sólidos, controle sobre desperdícios e retrabalhos no processo industrial.

Desta forma, o empreendimento não atende aos requisitos mínimos quanto às diretrizes das normas de certificação voltados a sistema de gestão da qualidade e ambiental, como exemplo, as certificações ISO 9.001/2008, ISO 14.001/2004, não sendo tomadas ações e medidas de combate à poluição, e que expõe o empreendimento à sanções penais e administrativas derivadas de condutas e atividades lesivas ao meio ambiente (lei federal no 9.605, de 12/02/1998, lei estadual $n^{\circ} 4.701 / 1992$ e municipal no $\left.5.617 / 2015\right)$.

\subsubsection{Matérias-primas e insumos}

A quantidade mensal (em quilogramas) de matérias-primas utilizadas no processo de produção são apresentadas no Quadro 5, e a representação da quantidade média de consumo apresentadas na última coluna do quadro. Já nos Quadros 6 e 7 são apresentadas as informações referentes ao consumo de água e energia elétrica, que de modo indireto permite a avaliação de desempenho ambiental. Ressalta-se que os insumos diversos e matérias-primas utilizados são armazenados em área fechada, com telhado, não possuindo tanques de armazenamento de substâncias perigosas.

$E$ 
Quadro 5 - Matérias-primas, em quilogramas, utilizados durante o processo de produção industrial da gráfica VV entre janeiro a julho de 2016.

\begin{tabular}{|c|c|c|c|c|c|c|c|c|}
\hline $\begin{array}{c}\text { Relação de } \\
\text { matérias-primas }\end{array}$ & Janeiro & Fevereiro & Março & Abril & Maio & Junho & Julho & Média (Kg) \\
\hline Papel couche & 14.000 & 12.000 & 10.000 & 10.000 & 8.000 & 7.000 & 8.000 & 9.857 \\
\hline Papel offset & 300.000 & 230.000 & 212.000 & 206.000 & 190.000 & 180.000 & 220.000 & 219.714 \\
\hline Papel cartão & 4.000 & 3.000 & 2.000 & 1.000 & 2.000 & 1.000 & 1.000 & 2.000 \\
\hline Tintas & 200 & 220 & 200 & 180 & 170 & 170 & 180 & 189 \\
\hline TOTAL $(\mathbf{K g})$ & $\mathbf{3 1 8 . 2 0 0}$ & $\mathbf{2 4 5 . 2 2 0}$ & $\mathbf{2 2 4 . 2 0 0}$ & $\mathbf{2 1 7 . 1 8 0}$ & $\mathbf{2 0 0 . 1 7 0}$ & $\mathbf{1 8 8 . 1 7 0}$ & $\mathbf{2 2 9 . 1 8 0}$ & $\mathbf{2 3 1 . 7 6 0}$ \\
\hline
\end{tabular}

Fonte: $\mathrm{O}$ autor.

Quadro 6 - Insumos diversos, em quilogramas, utilizados durante o processo de produção industrial da gráfica VV entre janeiro a julho de 2016.

\begin{tabular}{|c|c|c|c|c|c|c|c|c|}
\hline Relação de insumos & Janeiro & Fevereiro & Março & Abril & Maio & Junho & Julho & Média (kg) \\
\hline Chapas metálica & 800 & 650 & 700 & 650 & 600 & 500 & 600 & 642,86 \\
\hline Revelador de chapa & 40 & 40 & 40 & 0 & 0 & 0 & 0 & 17,14 \\
\hline Álcool isopropílico & 40 & 40 & 40 & 30 & 20 & 20 & 20 & 30,00 \\
\hline Limpador de chapa & 3 & 2 & 2 & 2 & 2 & 2 & 2 & 2,14 \\
\hline Solventes & 5 & 5 & 5 & 5 & 5 & 5 & 5 & 5,00 \\
\hline TOTAL (Kg) & $\mathbf{8 8 8}$ & $\mathbf{7 3 7}$ & $\mathbf{7 8 7}$ & $\mathbf{6 8 7}$ & $\mathbf{6 2 7}$ & $\mathbf{5 2 7}$ & $\mathbf{6 2 7}$ & $\mathbf{6 9 7 , 1 4}$ \\
\hline
\end{tabular}

Fonte: O autor. 
Quadro 7 - Consumo de água e energia elétrica durante o processo de produção industrial da gráfica VV entre janeiro a julho de 2016.

\begin{tabular}{|c|c|c|c|c|c|c|c|c|}
\hline Relação de insumos & Janeiro & Fevereiro & Março & Abril & Maio & Junho & Julho & $\begin{array}{c}\text { Média de } \\
\text { consumo }\end{array}$ \\
\hline Água $\left.\mathbf{( m}^{\mathbf{3}}\right)$ & 33 & 31 & 33 & 19 & 16 & 15 & 15 & 23,143 \\
\hline Energia elétrica (Kwh) & 7.040 & 6.560 & 6.400 & 6.200 & 6.080 & 5.200 & 5.320 & $6.114,28$ \\
\hline
\end{tabular}

Fonte: O autor. 
A energia elétrica é fornecida pela concessionária local, assim como o fornecimento de água que são utilizados tanto no processo industrial quanto no uso administrativo. Cabe salientar que no processo de impressão offset a imagem é transferia da chapa para a blanqueta e desta para o substrato, envolvendo o uso de água neste processo, e também uso para resfriamento das máquinas de impressão.

Ao decorrer do monitoramento pode-se perceber o aumento no consumo de insumos e matérias-primas no mês de julho, refletindo em ligeiro aumento nos resíduos sólidos gerados, inferindo-se melhoria econômica com a otimização do processo industrial e aumento da produção.

\subsubsection{Oportunidades de melhoria do processo industrial}

Adotando os princípios da metodologia de $\mathrm{P}+\mathrm{L}$, observação rígida sobre o processo industrial, apresenta-se abaixo oportunidades de melhoria detectadas na Gráfica VV:

- $\quad$ Adequação da área de armazenamento temporário de RS (atendimento à NBR 11.174/1989);

- $\quad$ Adoção de valores à cultura organizacional;

- Melhoria na armazenagem dos insumos e material de uso geral;

- $\quad$ Redução de desperdício em todas as etapas do processo produtivo;

- Segregação e valorização de resíduos sólidos recicláveis, visando sua comercialização (papel branco, papel colorido, papelão);

- Reutilização de resíduos de papel como rascunho em teste/inspeção e acertos de impressão;

- Reduzir quantidade de tinta nos rolos de impressão, para evitar ressecamento;

- Envelopamento das latas de tintas e vernizes, evitando derramamento e contaminação;

- $\quad$ Contratar serviço de coleta e descontaminação de trapos/estopas; 
- Possibilidade de troca de tecnologia para gravação de chapa, sem uso de revelador e água;

- $\quad$ Possibilidade de recirculação de água para resfriamento das impressoras;

- Reutilização da água de saída dos aparelhos de ar condicionado;

- Redução no consumo de insumos diversos e de menor toxicidade, com foco na ecoeficiência;

- $\quad$ Substituição de aparelhos de ar condicionado para novos com selo de eficiência energética, e substituição de lâmpadas fluorescentes por lâmpadas de LED.

\subsection{DIAGNÓSTICO DO GERENCIAMENTO DE RESÍDUOS SÓLIDOS COM ENFOQUE EM P+L}

Durante o acompanhamento das atividades e observações rígidas baseadas nas diretrizes da metodologia de $\mathrm{P}+\mathrm{L}$, o diagnóstico do gerenciamento de resíduos sólidos possibilitou a identificação das oportunidades de melhorias de processo, fluxos operacionais e das fontes de geração.

O mapeamento do processo e identificação das fontes de geração de resíduos sólidos possibilitou estabelecer o controle das variáveis envolvidas no correto gerenciamento destes resíduos sólidos, o que possibilitou a escolha da estratégia e indicadores adequados para avaliação de desempenho ambiental, o que corrobora com Alves; Oliveira, (2007); Fagnani; Guimarães, (2017).

\subsubsection{Geração de resíduos sólidos}

O processo de pré-impressão e impressão são etapas que apresentam alta geração de resíduos sólidos, como embalagens de tonners e cartuchos, panos e estopas contaminadas, excesso de produção (papel), chapas de alumínio usadas, latas de tintas e em destaque os resíduos de aparas de papel. 
Na pós-impressão há menor volume de geração, constituído de grampos metálicos, plásticos, caixas de papelão ondulado, cintas para amarração.

A perda na produção por falha operacional pode ser observada nas etapas de gravação, impressão e acabamento, descartando-se produtos com manchas, falhas no corte, variação da tonalidade e impressões com defeito, e a perda por superprodução evidente quanto a produção superior à quantidade demandada, não sendo registrado e relacionado aos custos de produção, e consequentemente valoração do produto final

Salienta-se o alto volume de resíduos sólidos de aparas de papel em função de formato do produto impresso e processo de corte adotado, o qual influencia diretamente em perdas de matéria-prima, sendo o desperdício de produção considerado e aceito pelos envolvidos como evento natural do processo industrial.

Conforme exposto, são gerados resíduos sólidos em todo processo produtivo, sendo identificados e classificados na sua fonte de geração, inventariados sob as premissas da Resolução CONAMA no 313/2002, relacionando-os no Quadro 8 os tipos de resíduos sólidos e sua fonte de geração (etapa no processo produtivo), e os respectivos quantitativos de geração apresentados na Tabela 1.

Quadro 8 - Tipos de resíduos sólidos gerados durante o processo de produção industrial da Gráfica VV entre janeiro a julho de 2016.

\begin{tabular}{|c|c|}
\hline $\begin{array}{c}\text { Etapa no processo } \\
\text { produtivo }\end{array}$ & Tipo de resíduos sólidos gerados \\
\hline Pré-impressão & $\begin{array}{c}\text { Cartuchos de tonners e impressora, papel/papelão, } \\
\text { madeira, filme, EPI's, papel cerado, lâmpadas queimadas, } \\
\text { trapos e estopas contaminadas, embalagens diversas }\end{array}$ \\
\hline Impressão & $\begin{array}{c}\text { Embalagens de tintas, papel e plástico usado, aparas e } \\
\text { carcaças de adesivo, fitas, EPI's, chapas metálicas usadas, } \\
\text { panos e estopas, latas/bombonas, cartuchos de } \\
\text { impressoras, blanquetas contaminadas, filtros de água, } \\
\text { escovas e pincéis }\end{array}$ \\
\hline Pós-impressão & $\begin{array}{c}\text { Papel, papelão e plástico, aparas e carcaças de adesivos, } \\
\text { madeira, fitas adesivas, arames e fita de arquear metálica, } \\
\text { EPI's, trapos e estopas contaminados, lâmpadas } \\
\text { queimadas, paletes descartáveis }\end{array}$ \\
\hline
\end{tabular}

Fonte: O autor. 
Dado a homogeneidade quanto a classificação dos resíduos sólidos gerados, associou-se os tipos de resíduos sólidos conforme NBR 10.004/2004, definidos como resíduos sólidos não contaminados (RS-NC), resíduos sólidos diversos contaminados (RS-DC), resíduos sólidos recicláveis, estes divididos entre resíduos de papel/papelão e resíduos de chapas metálicas, sendo apresentado na Tabela 1 a quantidade dos resíduos sólidos gerados no período de janeiro a julho de 2016. 
Tabela 1 - Quantificação dos resíduos sólidos gerados durante o processo de produção industrial da Gráfica VV entre janeiro a julho de 2016.

\begin{tabular}{|c|c|c|c|c|c|c|c|c|c|}
\hline Tipo de RS (kg) & $\begin{array}{c}\text { Classificação } \\
\text { NBR } 10.004\end{array}$ & JAN & FEV & MAR & ABR & MAI & JUN & JUL & $\begin{array}{c}\text { Média de } \\
\text { geração } \\
(\mathrm{kg})\end{array}$ \\
\hline RS-DC & I & 1.609 & 1.166 & 904 & 662 & 610 & 560 & 689 & 886 \\
\hline RS-NC & II & 519 & 442 & 330 & 188 & 87 & 84 & 89 & 248 \\
\hline Papel/Papelão & IIB & 20.000 & 20.800 & 19.500 & 19.000 & 18.000 & 17.400 & 21.300 & 19.429 \\
\hline Chapas Metálicas & IIA & 600 & 700 & 630 & 620 & 620 & 560 & 710 & 634 \\
\hline Total gerado & & 22.728 & 23.108 & 21.364 & 20.470 & 19.317 & 18.604 & 22.788 & 21.197 \\
\hline
\end{tabular}

Fonte: $\mathrm{O}$ autor. 
Ao decorrer do monitoramento, os resíduos sólidos diversos contaminados (RS-DC) apresentou ligeiro aumento no mês de julho, podendo-se inferir no aumento do uso de tintas devido a um tipo exclusivo de produto, como encartes, panfletos e outros, contudo nota-se que o valor total mensal da geração de resíduos sólidos não distancia-se do valor médio de geração.

As ações do gerenciamento de resíduos sólidos com enfoque na $\mathrm{P}+\mathrm{L}$ pode desenvolver um novo comportamento produtivo, com aproveitamento máximo de matérias-primas e insumos, com a adoção de valores ecoeficientes e resultados, onde observa-se na Figura 13 a redução da geração de resíduos sólidos e o equilíbrio da geração a partir do terceiro mês de implementação do PGRS.

Figura 13 - Gráfico de geração de resíduos sólidos

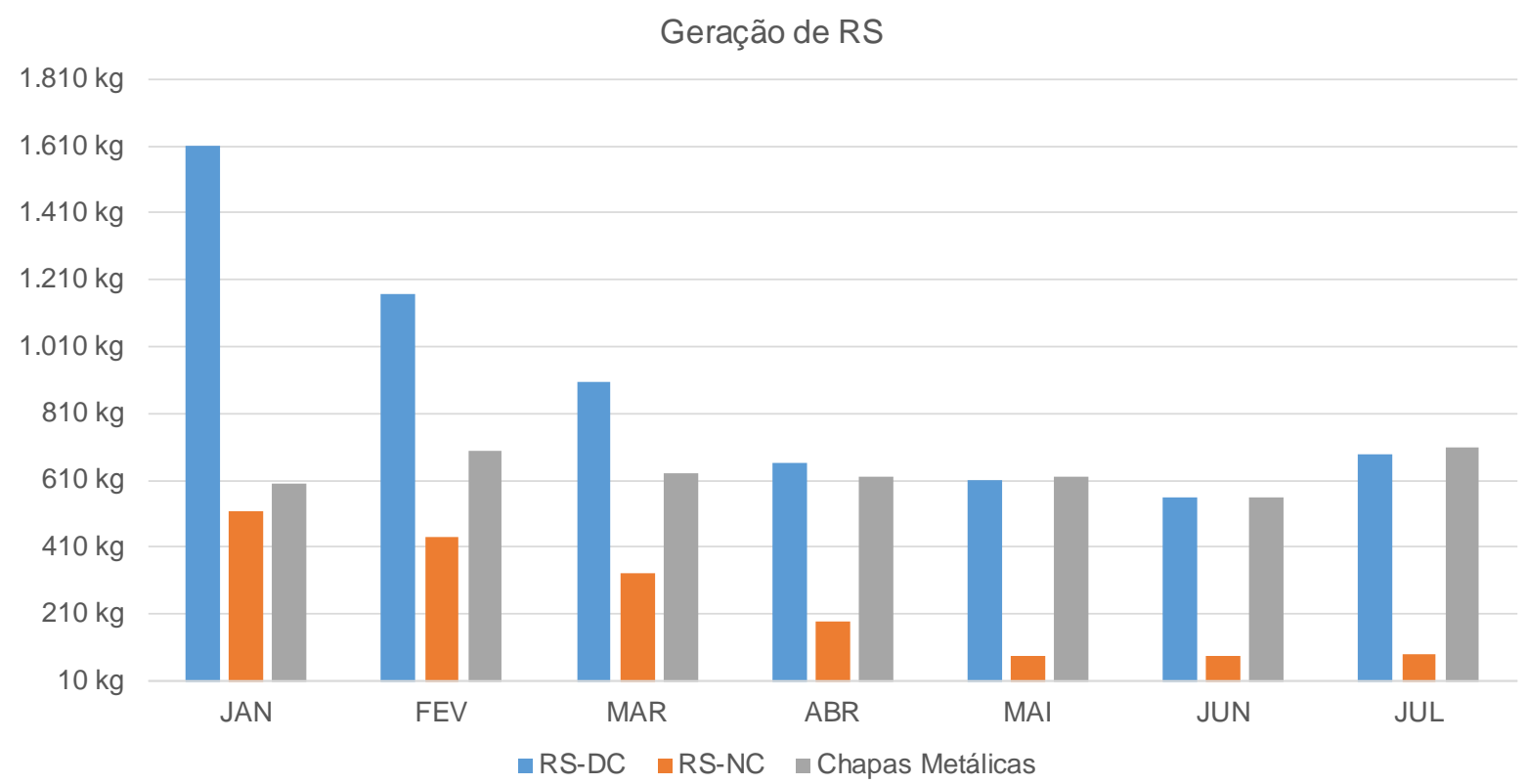

Fonte: O autor.

Quanto a geração de resíduos sólidos de papel/papelão, o gráfico abaixo (Figura 14) apresenta os valores de geração comparados com o consumo de papel (couche, offset e cartão). 
Figura 14 - Gráfico de consumo (matéria-prima) x RS de Papel/Papelão

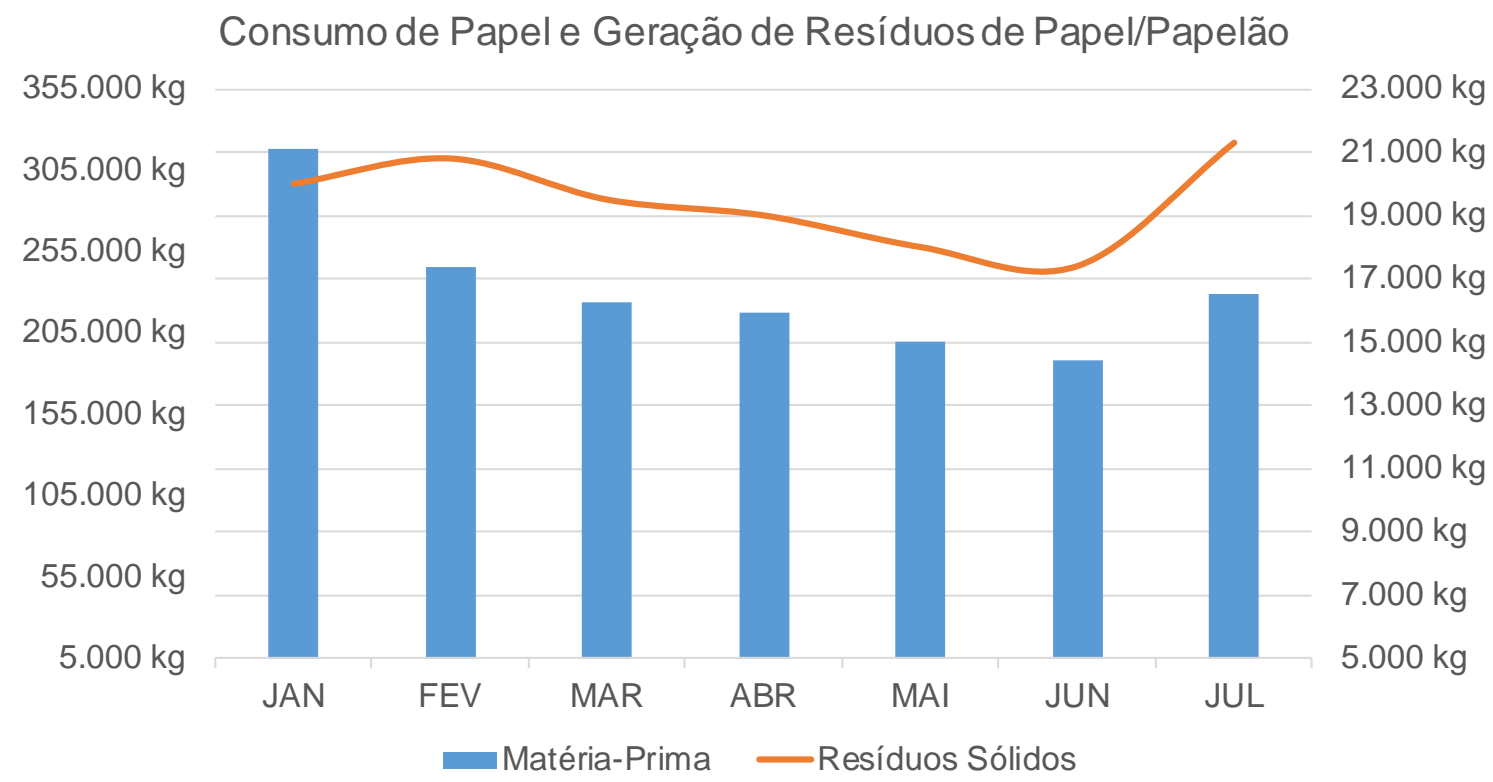

Fonte: O autor.

Pode-se inferir que o valor referente ao primeiro mês de monitoramento (janeiro) não representa a efetiva implantação do PGRS com enfoque nas premissas de $\mathrm{P}+\mathrm{L}$, visto que por hábito dos colaboradores, parte destes resíduos sólidos eram misturados com resíduos diversos da área administrativa. Este indício reforçou a aplicação de treinamento e motivação junto aos colaboradores, adotando ao resíduo valor e importância comercial, bem como o atendimento às prioridades de destinação final conforme legislação, procedendo, portanto, com a educação ambiental dos trabalhadores em acordo com a Lei no 9.795 de 27/04/1999.

A partir do segundo mês (fevereiro), obteve-se os valores reais quanto à efetiva implementação do PGRS, apresentando desta forma o equilíbrio entre consumo da matéria prima e a geração de resíduos sólidos de papel.

\subsubsection{Segregação e acondicionamento}

Diante a situação inicial do empreendimento em que não havia gestão sobre os resíduos sólidos gerados, não se praticava a segregação conforme sua identificação e classificação, sendo acondicionados a granel ou acondicionados em sacos plásticos 
(sacos de lixo, sacos de fibra) em coletores diversos sem padronização conforme CONAMA n 275/2001 e sem adoção de qualquer prática ambientalmente segura, não atendendo às diretrizes da NBR 11.174/1990, NBR 12.235/1992, Lei no 12.305/2010 e Decreto no 172 de 06/10/2015, observados nas Figuras de 15 a 18.

Figura 15 - Acondicionamento de RS em meio ao processo de produção
Figura 16 - Acondicionamento de RS em meio ao processo de produção

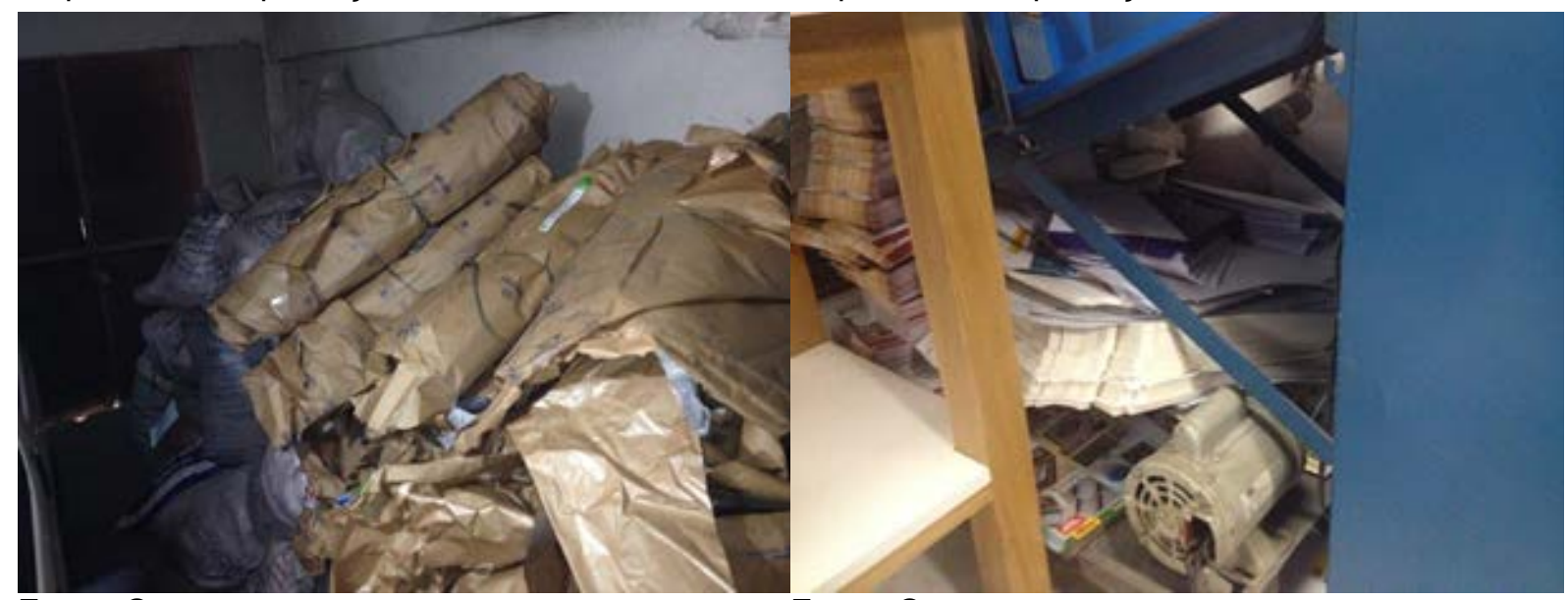

Fonte: O autor.

Figura 17 - Segregação incorreta com contaminação entre tipos de RS

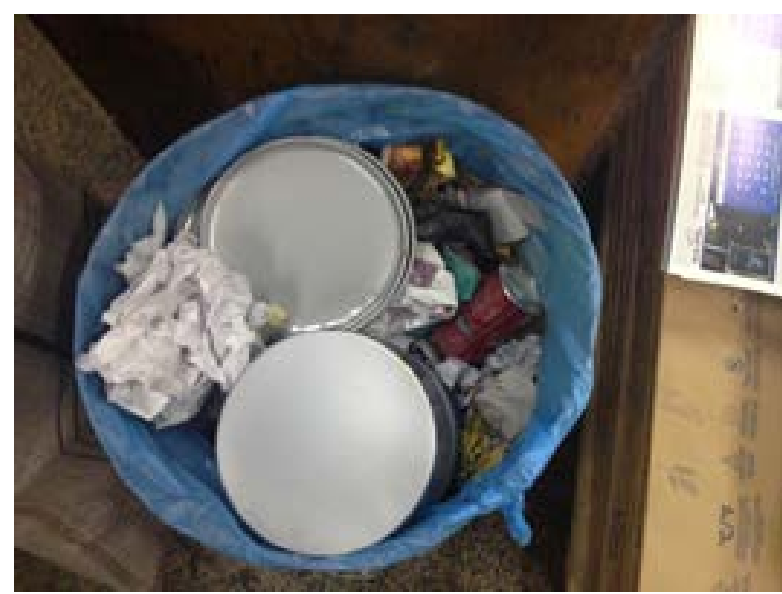

Fonte: O autor.
Figura 18 - Coletor de RS (saco de fibra ao fundo da figura)

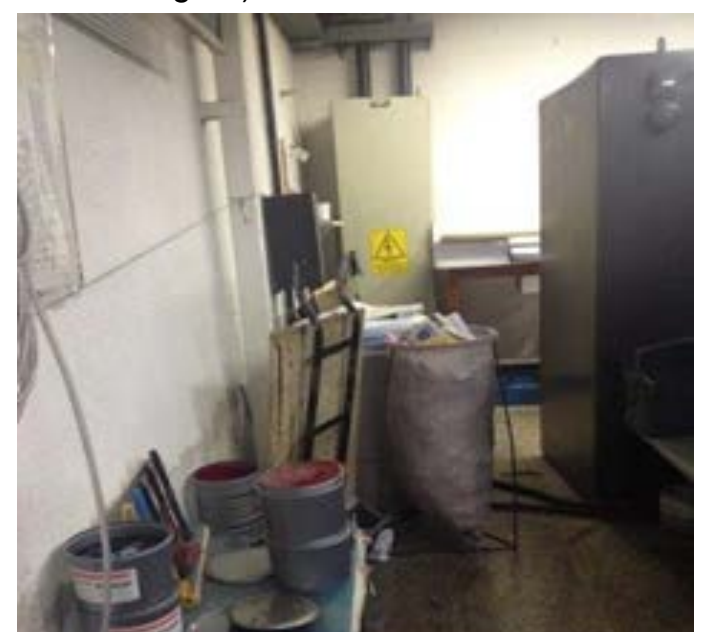

Fonte: O autor.

A falta de segregação influencia diretamente na forma de destinação final, sendo dispostos para coleta pública por ineficiência da segregação na fonte.

Durante a implementação do PGRS disponibilizou-se novos coletores e reposicionamento geral destes para mais próximos dos locais de maior geração, e centralização de coletor único para setores de baixa geração de resíduos sólidos. 
Considerando a homogeneidade dos resíduos sólidos gerados, as ações para correta segregação (visando segregação direta na fonte) foi procedida com o devido acondicionamento em recipientes compatíveis a cada tipo específico de resíduo sólido gerado e identificação deste recipiente, o que corrobora com Rocca e outros (1993), atendendo às diretrizes da NBR 11.174/1990, NBR 12.235/1992, Lei n 12.305/2010 e Decreto n¹72 de 06/10/2015, não optando, desta forma, com adoção da padronização de acondicionadores conforme a Resolução CONAMA n 275/2001.

Observou-se que o contexto em busca de adequação do processo produtivo desencadeou a sinergia das ações em prol da melhoria contínua e efetiva colaborações dos funcionários, que procederam com a correta segregação dos resíduos sólidos, em especial os recicláveis que possuem valor de venda (papel branco, papel colorido, chapas metálicas), também adotando-se práticas seguras quanto a segregação e acondicionamento dos resíduos sólidos contaminados, através de envelopamento de latas de tinta, evitando-se contaminação durante o transporte interno e manejo para o local de armazenamento temporário.

Os resíduos sólidos recicláveis (papel/papelão) passaram a ser segregados de melhor forma, com identificação dos acondicionadores quanto a papel de cor branca (predominância de aparas) ou impresso (predominância dos papeis com impressão colorida).

Os resíduos sólidos diversos contaminados passaram a ser acondicionados em coletores específicos e identificados (Figuras 19 a 22).

A participação dos envolvidos na implementação do PGRS e as ações voltadas à melhoria contínua quanto correta segregação e acondicionamento adequado dos resíduos sólidos, apontam a importância subjetiva inerente ao processo educacional, através da internalização dos conceitos de ecoeficiência e valores sustentáveis. 
Figura 19 - Coletor de resíduos perigosos

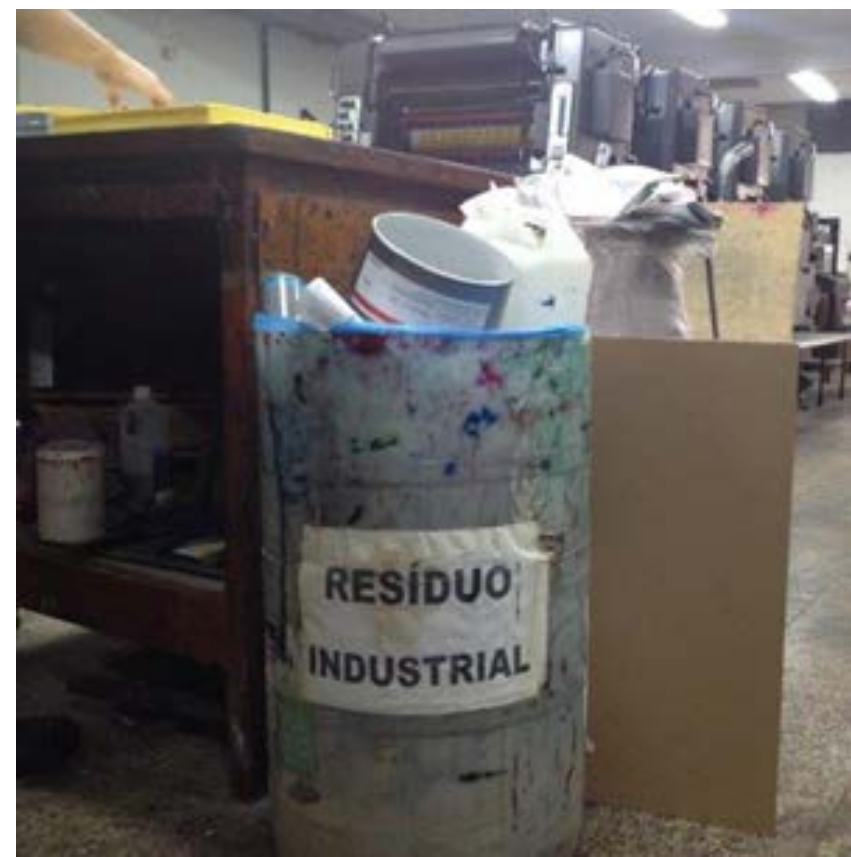

Fonte: O autor.
Figura 20 - Coleta de resíduos perigosos

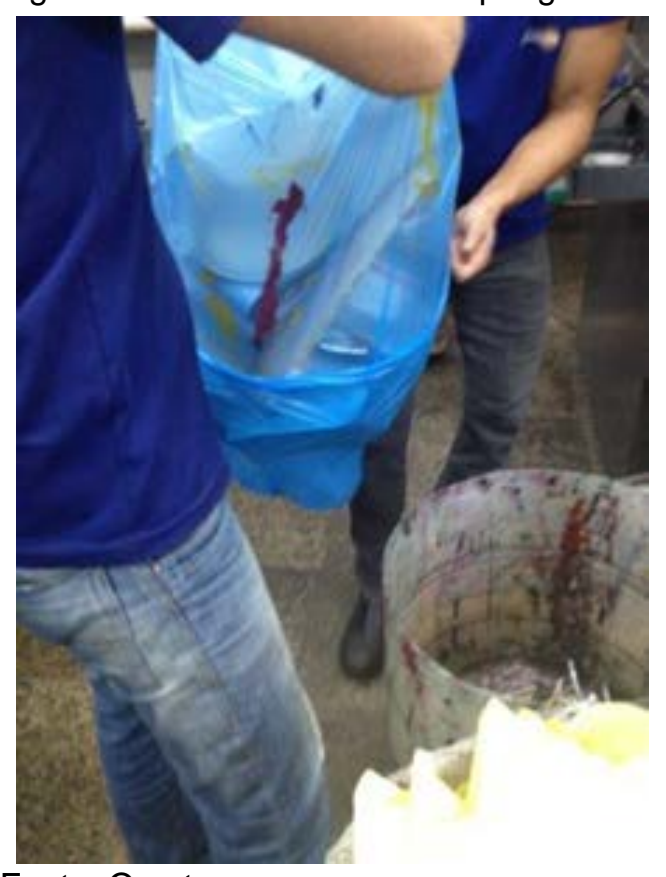

Fonte: O autor.
Figura 21 - Pesagem dos resíduos sólidos

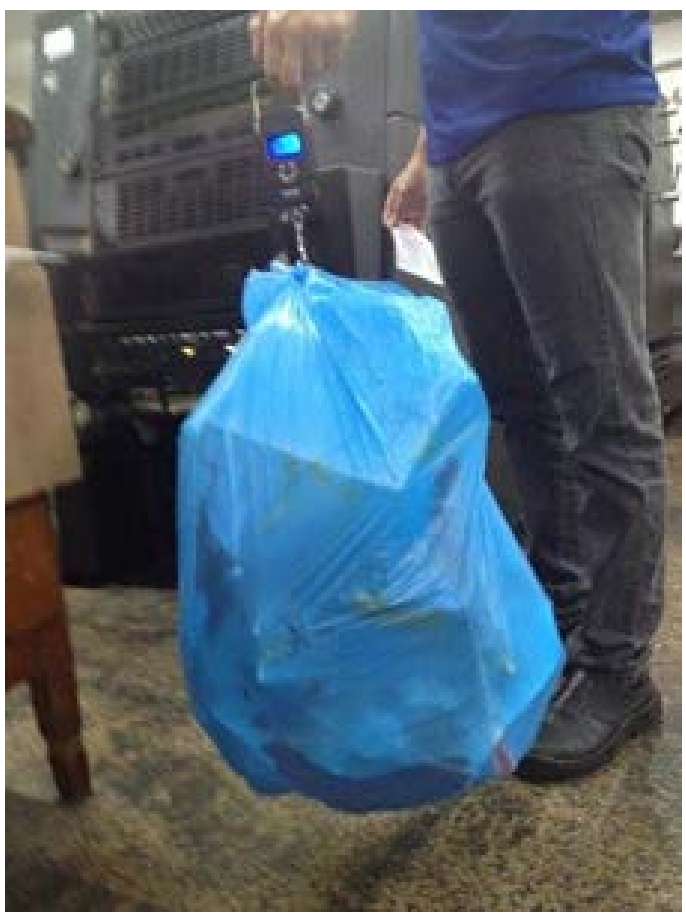

Fonte: O autor.
Figura 22 - Registro dos resíduos sólidos pesados

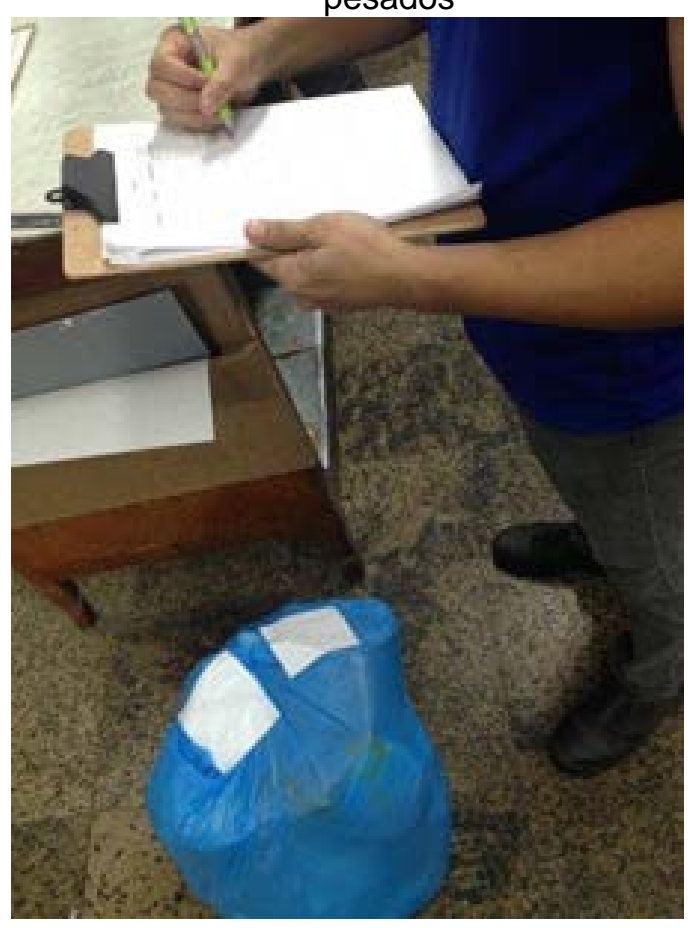

Fonte: O autor.

\subsubsection{Armazenamento temporário}


O armazenamento temporário dos resíduos sólidos do processo industrial é realizado em área anexa à infraestrutura do processo industrial, e que não dispunha de impermeabilização do solo, com volumes excessivos (grandes quantidades) de resíduos sólidos armazenados sem organização, identificação e com presença evidente de contaminação entre os resíduos sólidos perigosos e não perigosos, conforme apresentados nas Figuras 23 e 24.

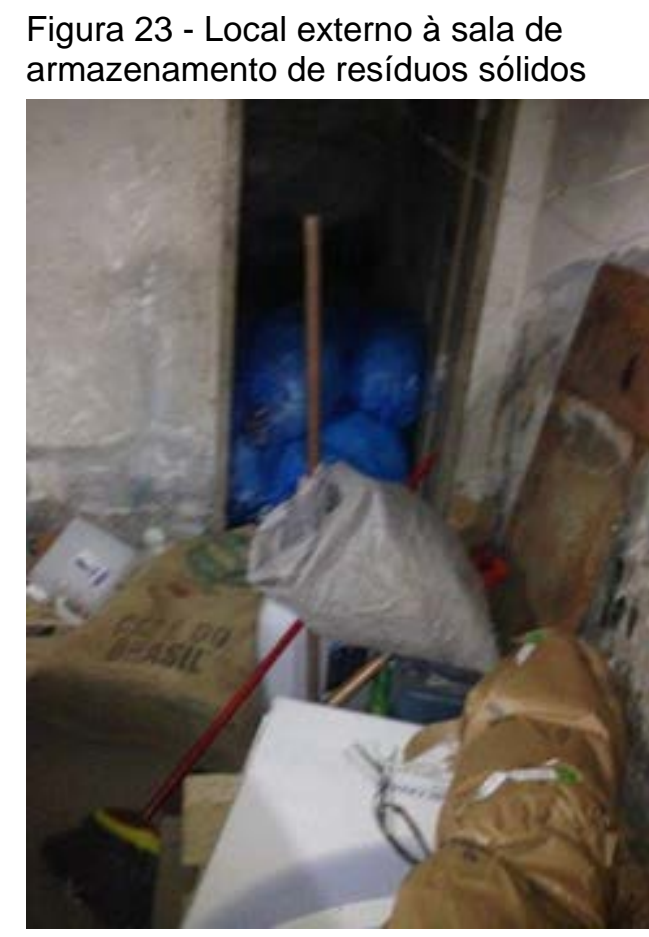

Fonte: $\mathrm{O}$ autor.
Figura 24 - Parte interna da sala de armazenamento de resíduos sólidos

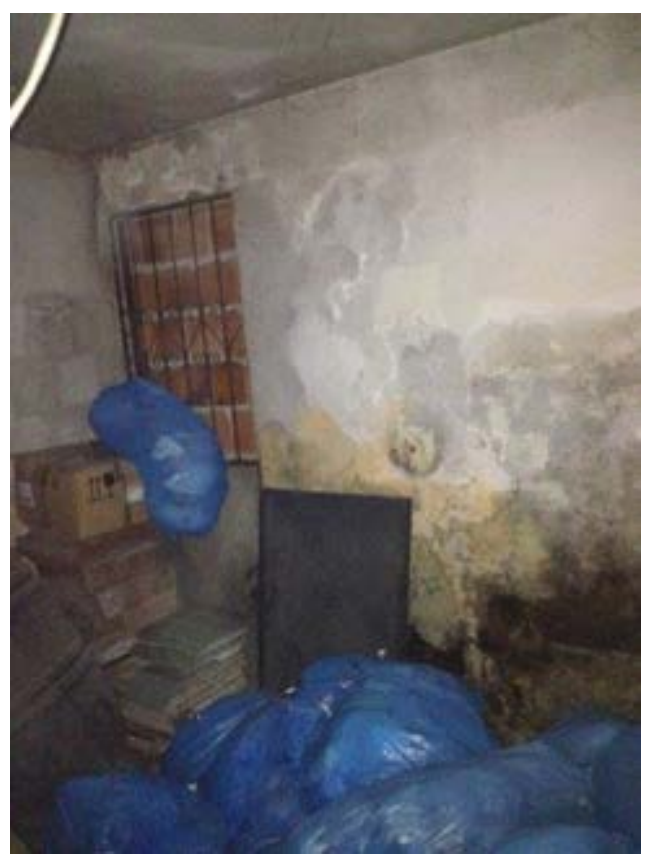

Fonte: O autor.

Diante as condições diagnosticadas, não atendendo às premissas normativas e legais, realizou-se imediata adequação de infraestrutura de área reservada do depósito para armazenamento temporário exclusivo dos resíduos sólidos perigosos, visando atendimento às diretrizes das normas ABNT NBR 11.174/1989 e 12.235/1992, podendo-se observar a implantação das oportunidades de melhorias nas Figuras 25, 26 e 27. 
Figura 25 - Adequação da infraestrutura para armazenamento temporário RS

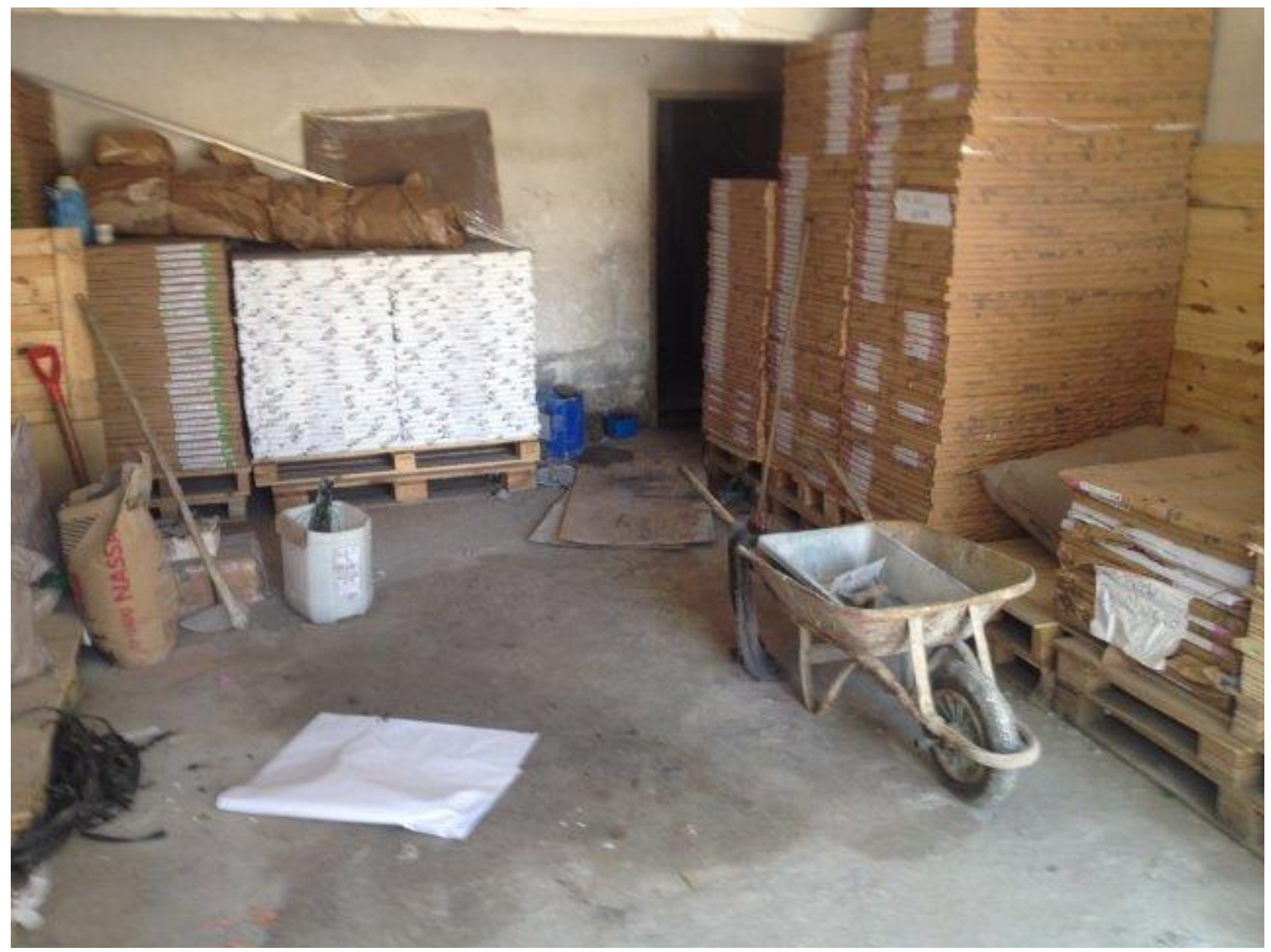

Fonte: O autor.

Figura 26 - Impermeabilização de piso

Figura 27 - Armazenamento de RS perigosos

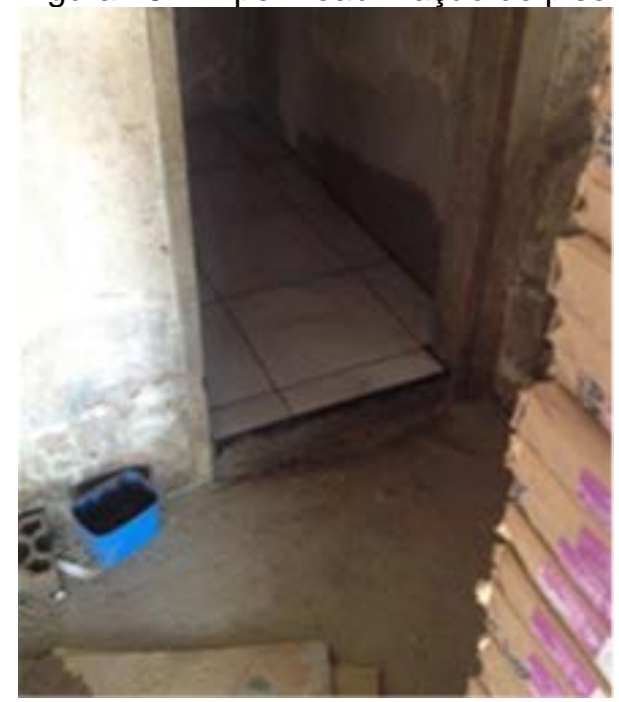

Fonte: O autor.

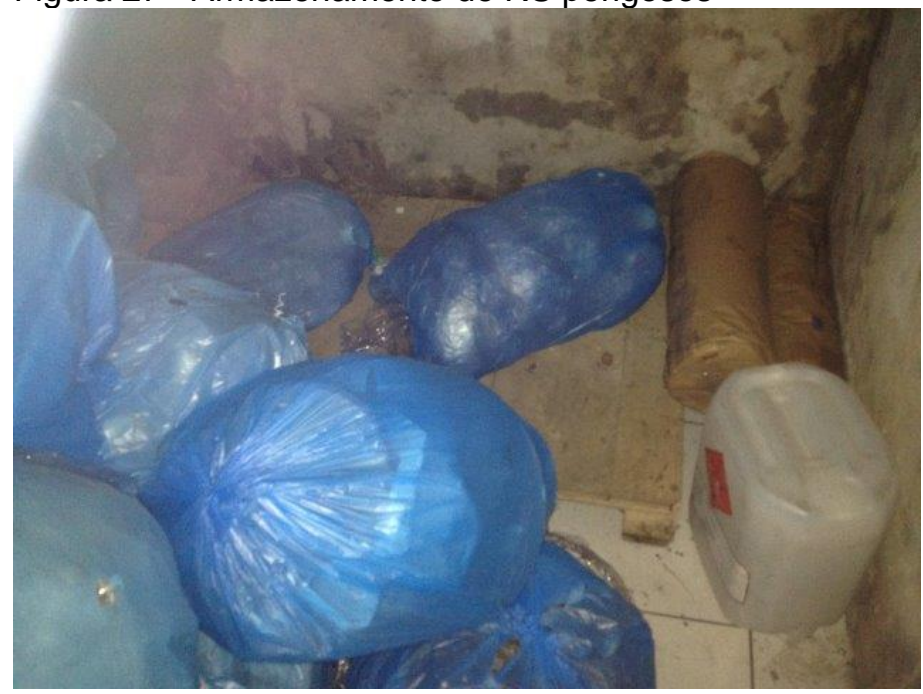

Fonte: O autor.

Portanto, adotadas as oportunidades de melhoria do processo industrial, a Gráfica VV passou a atender as normas e leis aplicáveis ao gerenciamento de resíduos sólidos. 


\subsubsection{Coleta e transporte}

Os resíduos sólidos gerados, segregados e acondicionados são transportados internamente no empreendimento do ponto de geração do processo industrial até o ponto de armazenamento temporário.

Externamente são coletados e transportados por empresas especializadas. Durante o desenvolvimento da pesquisa foi possível acompanhar eventualmente a coleta externa de resíduos sólidos, verificando-se o atendimento às diretrizes da ABNT NBR 13.463/1995, NBR 13.221/2007, NBR 7.500/2005, NBR 7.503/2005, 7.504/1993.

\subsubsection{Destinação final}

Os resíduos sólidos perigosos do processo industrial eram destinados a aterro industrial privado em mínima quantidade, visto que não havia segregação, enquanto os demais resíduos sólidos do empreendimento eram encaminhados para o sistema de coleta pública e destinados em aterro sanitário municipal.

Durante as alterações de infraestrutura do local de armazenamento temporário de RS, procedeu-se com a gestão destes resíduos sólidos conforme Resolução CONAMA nº 307/2002, mantendo-se o padrão de destinação final dos resíduos sólidos industriais conforme PGRS. Contudo, através da adoção de melhores práticas de segregação, acondicionamento e armazenamento, os resíduos sólidos recicláveis passaram a ser comercializados com venda direta para a indústria recicladora, agregando recursos financeiros à Gráfica VV.

O diagnóstico do gerenciamento de resíduos sólidos com enfoque na $\mathrm{P}+\mathrm{L}$ e efetiva implementação do PGRS promoveu meios dos quais os indivíduos e coletividade construíssem valores sociais, conhecimentos, habilidades, atitudes e competências voltadas para a conservação do meio ambiente, para bem de uso comum essencial à sadia qualidade de vida e sustentabilidade, conforme preconiza a Lei 9.795/1999.

Portanto a destinação final adotada pela Gráfica VV atende aos requisitos normativos e legais, como a Lei n¹2.305/2010 (PNRS), Lei estadual n 9.264/2009 (PERS), Lei $6.834 / 2001$, Lei municipal no 2.915/1994, decretos no 172/2015 e n 15/2016. 


\subsection{AVALIAÇÃO DO DESEMPENHO DA IMPLEMENTAÇÃO DO PGRS}

Tomando-se como base a NBR 14.031/2002 que estabelece diretrizes para um processo de Avaliação do Desempenho Ambiental, o método desta avaliação possibilitou relacionar o processo produtivo quanto ao consumo de matérias-primas e a geração de resíduos sólidos, determinando a evolução ambiental da empresa.

O desperdício de produção, erros de processo (retrabalho), superprodução e falta de correta segregação de resíduos sólidos recicláveis diagnosticados no estudo corrobora com os resultados de Terra e Wasserman (2013) sobre o grave problema do segmento industrial quanto à geração de resíduos sólidos, principalmente relacionados às perdas de produção.

A divulgação das informações, acompanhamento das atividades, envolvimento dos funcionários e sinergia das ações em prol de objetivo comum resultou em uma mudança da cultura organizacional com a incorporação da variável ambiental no dia a dia da empresa, observados pelo pesquisador e ações efetivadas ao início do monitoramento e desenvolvimento participativo dos processos aplicados à realidade do empreendimento, solidificadas a partir do terceiro mês da implementação.

\subsubsection{Indicador da geração de resíduos sólidos por matéria-prima consumida}

Utilizando-se dos dados levantados quanto a geração mensal de cada tipo de resíduo sólido e aplicando-se ao indicador da geração de resíduos sólidos por matérias-primas (MP) consumidas no processo industrial durante o período de monitoramento, apresenta-se na Tabela 2 os resultados adquiridos.

Tabela 2 - Indicador da geração de resíduos sólidos por matéria-prima consumida na gráfica VV no período de janeiro a julho de 2016.

\begin{tabular}{c|c|c|c|c}
\hline Mês & $\begin{array}{c}\text { RS-NC I } \\
\text { MP }\end{array}$ & $\begin{array}{c}\text { RS-DC I } \\
\text { MP }\end{array}$ & $\begin{array}{c}\text { Papel/Papelão I } \\
\text { MP }\end{array}$ & $\begin{array}{c}\text { Chapas Metálicas I } \\
\text { MP }\end{array}$ \\
\hline Janeiro & $0,51 \%$ & $0,16 \%$ & $6,29 \%$ & $0,19 \%$ \\
\hline Fevereiro & $0,48 \%$ & $0,18 \%$ & $8,48 \%$ & $0,29 \%$ \\
\hline
\end{tabular}




\begin{tabular}{c|l|l|l|l}
\hline Março & $0,40 \%$ & $0,15 \%$ & $8,70 \%$ & $0,28 \%$ \\
\hline Abril & $0,30 \%$ & $0,09 \%$ & $8,75 \%$ & $0,29 \%$ \\
\hline Maio & $0,30 \%$ & $0,04 \%$ & $8,99 \%$ & $0,31 \%$ \\
\hline Junho & $0,30 \%$ & $0,04 \%$ & $9,25 \%$ & $0,30 \%$ \\
\hline Julho & $0,30 \%$ & $0,04 \%$ & $9,29 \%$ & $0,31 \%$ \\
\hline
\end{tabular}

Fonte: O autor.

Legenda de siglas: RS-NC - Resíduo Sólidos não contaminados; RS-DC - Resíduos Sólidos diversos contaminado; MP - Matérias Primas

Aparentemente os percentuais apresentam-se em valores baixos, entretanto cabe salientar que determinou-se como parâmetro comparativo de desempenho ambiental o consumo de matéria-prima (entrada) e a geração de cada tipo específico de resíduo sólido (saída). Portanto, como exemplo no mês de janeiro/2016 o consumo de $318.200 \mathrm{~kg}$ de matérias-primas no processo gerou um total $22.728 \mathrm{~kg}$ de resíduos sólidos, o que representa, portanto, 7,14\% de resíduos sólidos na produção, margem prevista pelo SINDIGRAF (2006) e abaixo da média apresentada pela PIA (2003).

Os resíduos sólidos não contaminados (RS-NC) apresentavam inicialmente 0,51\% $(1.609,00 \mathrm{~kg})$ de geração sobre o consumo de matéria-prima $(318.200,00 \mathrm{~kg})$ ao início do monitoramento. O valor de geração passou a ser reduzido conforme andamento da pesquisa e implantação das melhorias de processo. Com a devida segregação dos resíduos sólidos não contaminados, o percentual de geração estabilizou-se em 0,30\%, tratando-se de resíduos sólidos não passíveis de reciclagem, resíduos de varrição e diversos, tendo-se como parâmetro indicador as matérias-primas de entrada, estabelece-se maior confiabilidade no dado quanto a variação de produção.

Inicialmente à implementação do PGRS observou-se o valor geração de 6,29\% de resíduos de papel/papelão, percentual próximo ao padrão para este tipo de resíduo sólido conforme dados do SINDIGRAF (2006) em que variam entre 5\% a 36\% do volume produzido numa indústria gráfica. Contudo pode-se inferir que o valor inicial não representa um valor efetivo de implementação do PGRS, sendo parte dos resíduos sólidos misturados com resíduos comuns (resíduos sólidos da área administrativa). Com o conhecimento claro dos envolvidos sobre os processos internos e integração entre as áreas de produção, adoção de novos padrões e atitudes proativas quanto à maximização da segregação destes resíduos sólidos, o indicador 
apresentou crescimento do percentual de resíduos de papel/papelão, podendo-se inferir na mudança de cultura organizacional e que corroborou com a redução dos valores referentes aos resíduos sólidos não contaminados (RS-NC).

Da mesma forma quanto a avaliação dos resíduos de papel/papel houve aumento no valor dos resíduos de chapas metálicas e que tenderam a um valor médio de geração de 0,30\%. Ressalta-se que ao início do monitoramento os resíduos de chapas metálicas não eram segregados em sua totalidade, tendo destinação final dada junto a outros tipos de resíduos sólidos. A partir da correta e eficaz segregação, estes resíduos sólidos passaram a ser destinados para indústria recicladora, também agregando receita ao empreendimento com sua venda.

Quanto aos resíduos sólidos diversos contaminados (RS-DC), observa-se a redução de sua geração no processo industrial. Dentre as ações de melhoria e busca por alternativas de destinação final, em acordo com as prioridades estabelecidas na PNRS, destaca-se a alteração do tratamento dado aos resíduos perigosos com maior volume de maior geração, sendo respectivamente panos/estopas contaminadas.

A partir de abril/2016 os panos/estopas contaminados deixaram de ser destinados à aterro industrial e passaram a ser encaminhados para lavagem e descontaminação em empresa especializada e retornados à Gráfica VV para reuso, o que resultou na redução de 0,16\% para 0,04\% de geração de RS-DC, observando a estabilização nos valores de geração nestes meses.

A redução da geração dos tipos de resíduos sólidos atende ao princípio básico da metodologia de $\mathrm{P}+\mathrm{L}$ e de um PGRS, assim como as prioridades da PNRS como a redução da geração e reciclagem.

Conforme acima exposto, observa-se no gráfico abaixo (Figura 28) o desempenho da implementação do PGRS.

Figura 28 - Gráfico de desempenho da implementação do PGRS 


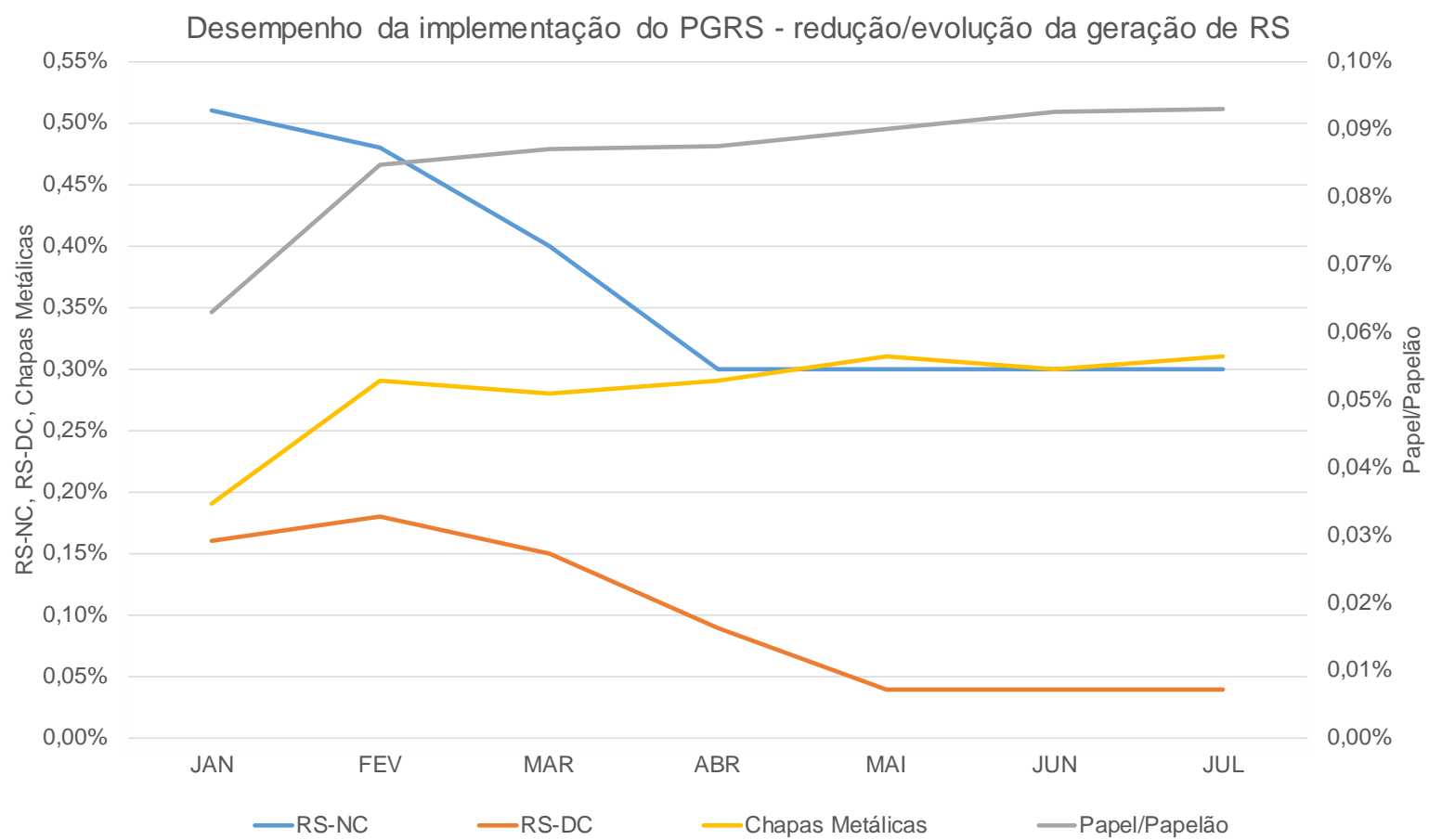

Fonte: O autor.

Legenda de siglas: RS-NC - Resíduos Sólidos não contaminados; RS-DC - Resíduos Sólidos diversos contaminado; MP - Matérias Primas

Conforme apresentado na Figura 28, observa-se que os índices (percentuais) de geração apresentam uma tendência ao equilíbrio no processo industrial, proporcionado pela otimização do processo industrial e sequente redução da poluição ambiental, o que corrobora os estudos de Hinz; Valentina e Franco, (2006); Wang; Yan e Hu (2016).

Desta forma, pode-se inferir que todas as ações da implementação do PGRS, destacando a adoção dos valores ecoeficientes pelos envolvidos, avaliando o resultado como satisfatório, com efetiva maximização do uso de todos os recursos necessários à atividade produtiva, sendo, portanto, aceitável e recomendado o aumento dos valores referentes à geração de resíduos sólidos recicláveis.

\subsubsection{Indicador do tipo de destinação ambientalmente adequada}


Quanto a avaliação da forma de destinação final dada aos resíduos sólidos gerados, apresenta-se o indicador do tipo de tratamento dado quanto ao percentual de resíduos sólidos gerados durante os meses de janeiro a julho de 2016 (Tabela 3).

Tabela 3 - Indicador do tipo de destinação final aplicada aos resíduos sólidos gerados durante os meses de janeiro a julho de 2016.

\begin{tabular}{c|c|c|c}
\hline Mês & $\begin{array}{c}\text { Aterro Industrial - } \\
\text { Classe II }\end{array}$ & $\begin{array}{c}\text { Aterro Industrial - } \\
\text { Classe I }\end{array}$ & Reciclagem \\
\hline Janeiro & $7,08 \%$ & $2,28 \%$ & $90,64 \%$ \\
\hline Fevereiro & $5,05 \%$ & $1,91 \%$ & $93,04 \%$ \\
\hline Março & $4,23 \%$ & $1,54 \%$ & $94,22 \%$ \\
\hline Abril & $3,23 \%$ & $0,92 \%$ & $95,85 \%$ \\
\hline Maio & $3,16 \%$ & $0,45 \%$ & $96,39 \%$ \\
\hline Junho & $3,01 \%$ & $0,45 \%$ & $96,54 \%$ \\
\hline Julho & $3,02 \%$ & $0,39 \%$ & $96,59 \%$ \\
\hline
\end{tabular}

Fonte: $\mathrm{O}$ autor.

As ações de segregação e armazenamento dos resíduos sólidos devidamente identificados e dispostos de modo organizado possibilitaram reduzir a destinação para aterro industrial classe II (resíduos sólidos não contaminados), destinação em aterro industrial classe I (resíduos sólidos contaminados) e aumento dos resíduos sólidos encaminhados para reciclagem.

Com a correta e efetiva segregação dos resíduos sólidos, realizou-se a valoração dos resíduos sólidos recicláveis e oportunidades de reuso, e geração de receita com a venda destes resíduos sólidos.

Os resíduos de papel/papelão, divididos em aparas coloridas e aparas brancas, passaram a ter maior valor econômico de venda para a indústria recicladora, enquanto os resíduos de papel/papelão oriundos de outros processos produtivos.

Com o conjunto de ações exercidas, direta ou indiretamente, observou-se a adoção valores ecoeficientes, percepção do processo industrial quanto aos aspectos e impactos ambientais, mudança de atitudes e comportamento dos envolvidos na 
implementação do PGRS, podendo-se observar (Figura 29) o desempenho da implementação do PGRS quanto a redução da geração de resíduos sólidos e respectiva representação do desempenho quanto aos sólidos gerados encaminhado a uma destinação final ambientalmente adequada.

Figura 29 - Gráfico de desempenho quanto à forma de destinação final dos RS

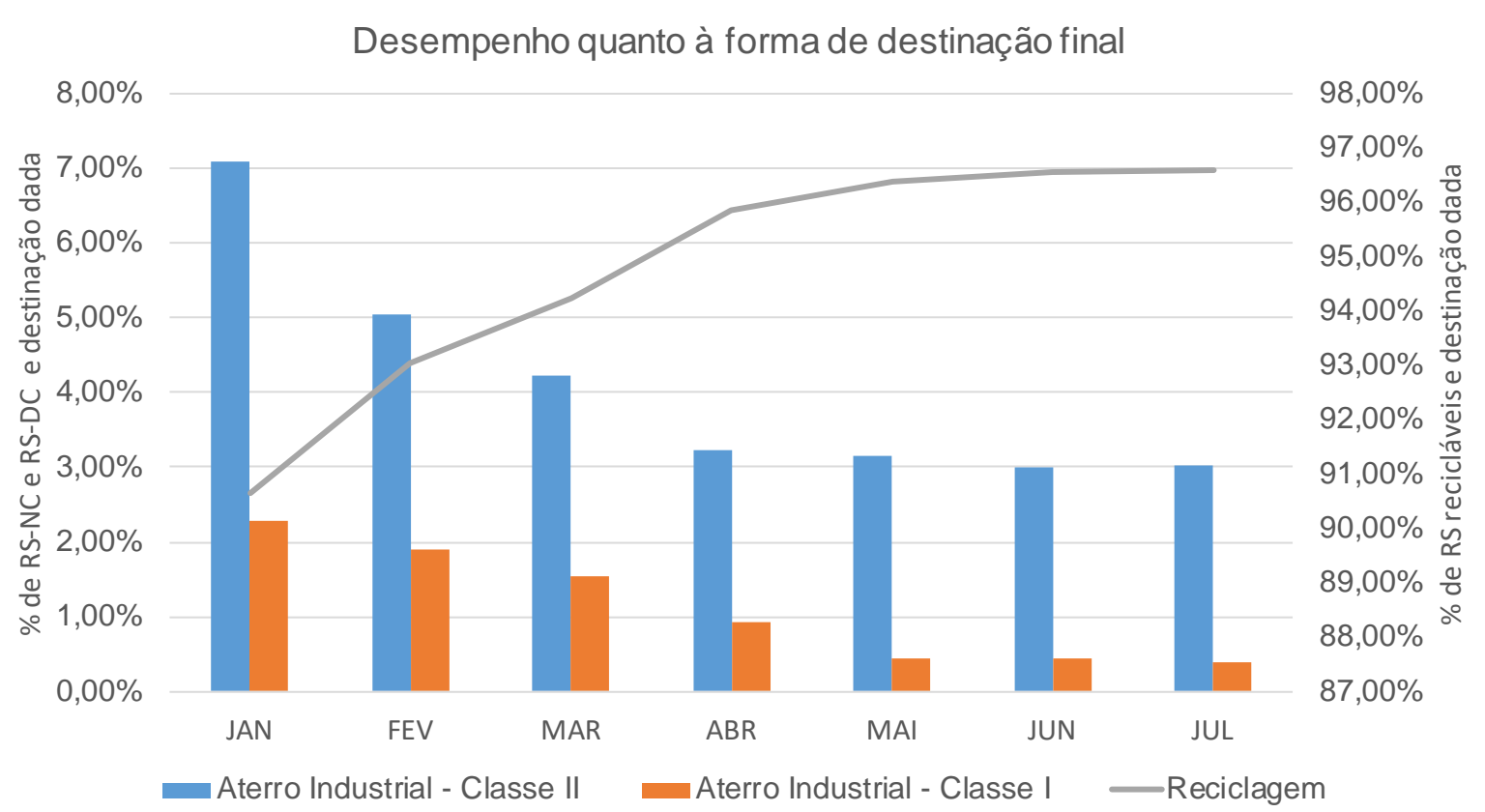

Fonte: $\mathrm{O}$ autor.

As formas de destinação final atende satisfatoriamente as premissas legais e normativas, reduzindo de modo geral custos com destinação final e ainda possibilitou a geração de receita com a comercialização dos resíduos sólidos recicláveis, avaliando-se como efetiva e satisfatória o tipo de destinação final ambientalmente adequada dada aos RS da Gráfica VV.

\subsubsection{Indicador de ecoeficiência quanto ao consumo de matéria-prima e insumos}


Como valor base de comparação, considerou-se o valor da média de consumo de todo o período (janeiro a julho) em razão do valor de consumo mensal. Tomando-se como exemplo o mês de janeiro, aplica-se o valor da média de consumo de matérias-primas de todo período $(231.760,00 \mathrm{~kg})$ em razão do valor do consumo mensal (318.200,00kg), o que resulta em $137 \%$ para comparativo inicial, que neste caso relaciona-se com a ecoeficiência do processo e evolução do desempenho ambiental da gráfica.

Observa-se na Tabela 4 a evolução do consumo de matérias-primas e insumos, em que o parâmetro de 100\% refere-se ao valor base (médio).

Tabela 4 - Indicador da evolução do consumo de matérias-primas e insumos utilizados pela gráfica VV, durante os meses de janeiro a julho de 2016.

\begin{tabular}{c|c|c|c}
\hline Mês & Matéria-prima & Água & Energia elétrica \\
\hline Janeiro & $137 \%$ & $143 \%$ & $115 \%$ \\
\hline Fevereiro & $106 \%$ & $134 \%$ & $107 \%$ \\
\hline Março & $97 \%$ & $143 \%$ & $105 \%$ \\
\hline Abril & $94 \%$ & $82 \%$ & $101 \%$ \\
\hline Maio & $86 \%$ & $69 \%$ & $99 \%$ \\
\hline Junho & $81 \%$ & $65 \%$ & $85 \%$ \\
\hline Julho & $99 \%$ & $65 \%$ & $87 \%$ \\
\hline
\end{tabular}

Fonte: $\mathrm{O}$ autor.

Observa-se ainda na Tabela 4 a evolução quanto ao consumo de matérias-primas no processo industrial, destacando-se a eficiência de 30\% entre janeiro a março, inferindo um equilíbrio de acordo com o avanço da produção da Gráfica VV, minimizando e mitigando os impactos ambientais gerados pela produção, o que de acordo com Massote; Santi (2013); Silva e outros (2013), contribui com a sustentabilidade ambiental e econômica da empresa.

Salienta-se aumento gradual na geração de resíduos no mês de julho, acompanhado pelo aumento da produção e demanda por matérias-primas, podendo-se inferir na prosperidade da gráfica junto ao segmento de negócio no estado do Espírito Santo. 
Incorporada a ideia de melhoria contínua, o empreendimento adotou a substituição de todas as lâmpadas fluorescentes por lâmpadas de LED, substituição dos aparelhos de ar condicionado para novos com selo de melhor nível de eficiência energética, instalando também uma cortina física de separação entre a área do processo de impressão e área de acabamento para redução do uso dos aparelhos de ar condicionado, o que representou na redução do consumo de energia elétrica de 7.040Kwh (janeiro) para 5.320Kwh (julho).

Nesta ideia, o empreendedor aderiu à oportunidade de melhoria diagnosticada quanto a mudança da tecnologia de sistema de gravação das chapas metálicas. Este novo sistema possibilitou a gravação e a sensibilização do material com fotolito já aderido à chapa por vácuo, eliminando a utilização de água no processo de revelação, o que justifica a redução no consumo de água do processo industrial a partir do mês de abril, podendo-se inferir no equilíbrio do consumo destes insumos nos meses subsequentes.

Apresenta-se na Figura 30 o gráfico de ecoeficiência do processo industrial, observando as efetivas ações de implementação do PGRS, proporcionando otimização do processo industrial e a sustentabilidade ambiental da Gráfica VV, o que atende a Política Nacional do Meio Ambiente (PNMA) e corrobora com Kubota; Campos; Cauchick-Miguel, 2014; Klemes; Varbanov; Huising, 2012; Silva; Medeiros, 2004; Cagno; Trucco; Tardini, 2005; Chavan, 2005. 
Figura 30 - Gráfico de ecoeficiência do processo industrial

Gráfico de ecoeficiência do processo industrial da Gráfica W

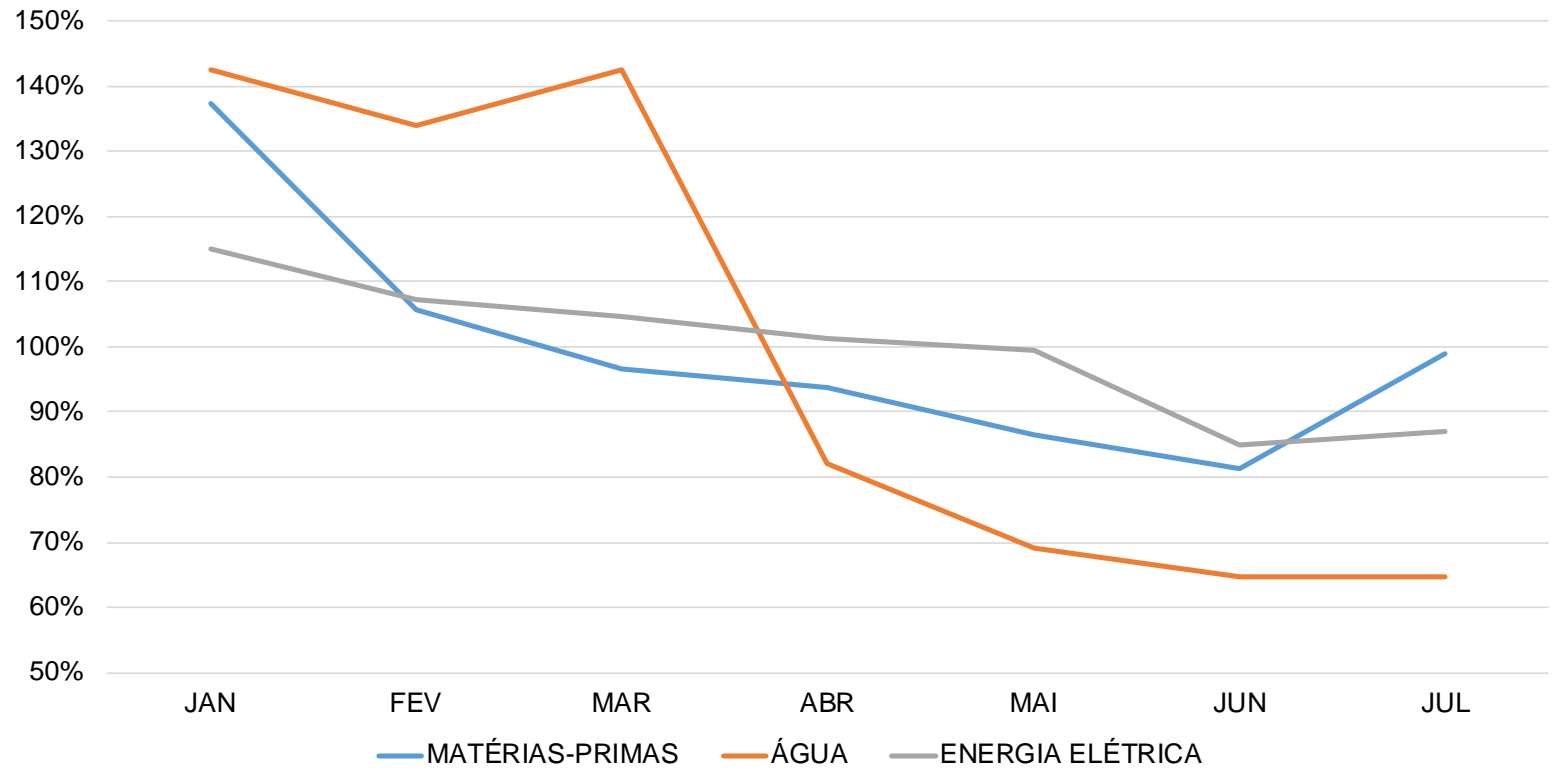

Fonte: O autor.

Avalia-se a ações proativas e efetivas em relação ao atendimento a legislação, da redução e controle de consumo de insumos e matérias-primas, e da sustentação das vantagens competitivas enfatiza a integração positiva dos sistemas de gestão $(P+L$ e PGRS), levando a Gráfica VV à prática da responsabilidade socioambiental. 


\section{CONCLUSÃO}

A partir do diagnóstico realizado foi possível identificar que a empresa não atendia aos requisitos mínimos quanto ao controle da poluição e imperativos legais, apresentando cenário para pesquisa e estudo.

A implementação do PGRS com enfoque na $P+L$ serviu como instrumento de aperfeiçoamento da operacionalização da Gráfica $\mathrm{VV}$, ao ponto de minimizar os impactos ambientais e econômicos inerentes ao seu funcionamento, devido a melhoria organizacional, aumento da ecoeficiência produtiva, atendimento as prerrogativas legais dos órgãos fiscalizatórios, redução de custos e aumento de competitividade no mercado, além de permitir valor agregado ao produto final, alcançando todos os objetivos propostos nesta pesquisa.

Salienta-se que o método utilizado foi capaz de combinar fatores como atitude (valores) e comportamento, resultando no progresso quanto às ações de implementação do PGRS e implementação de demais ações ligadas à $P+L$ e com a internalização dos conceitos metodológicos a Gráfica VV teve a oportunidade de entender a importância do gerenciamento dos resíduos sólidos e observação de oportunidades de melhorias dos processos para redução dos impactos ambientais e econômicos, proporcionando adoção de estratégias de mercado e, em longo prazo, um caminho para sustentabilidade do empreendimento. 


\section{RECOMENDAÇÕES}

Com os conhecimentos e os resultados apresentados sugere-se que as indústrias do ramo gráfico explorem a metodologia adotada, integrando as ações da $P+L$ ao $P G R S$.

Recomenda-se a adoção sistemática de indicadores ambientais padronizados ao segmento, sendo devidamente divulgado pelos sindicatos e associações, o que permitirá que todo o setor gráfico caminhe rumo aos mesmos objetivos, em um processo de melhoria contínua focado no desenvolvimento sustentável.

Para trabalhos futuros pode-se expandir horizontes de pesquisa abordando o impacto econômico e retorno financeiro quanto ao investimento em tecnologias avançadas, visando a automatização e informatização dos processos inserindo as tratativas de gerenciamento dos resíduos sólidos no processo de gestão empresarial, bem como utilização de insumos e matérias-primas ecoeficientes, possibilitando a geração de informações para incentivo a investimentos em tecnologia ecoeficientes e implantação de novos empreendimentos para expansão do setor. 
ASSOCIAÇÃO BRASILEIRA DA INDÚSTRIA GRÁFICA - ABIGRAF. Estudo Setorial da Indústria Gráfica no Brasil. São Paulo, SP. 2009.

- Regional Santa Catarina. Guia Ambiental da Indústria Gráfica Catarinense. $1^{\text {a }}$ Edição - Santa Catarina, SC: ABIGRAF / SENAI/SC. 2009.

. Dados Econômicos. Disponível em: <http:// www.abigraf.org.br>. Acesso $\overline{\text { em } 05}$ de agosto de 2015.

. Dados Econômicos. Disponível em: <http:// www.abigraf.org.br>. Acesso em 05 de fevereiro de 2017.

A certificação FSC na Indústria Gráfica. Disponível em: <http:// www.abigraf.org.br>. Acesso em 01 de novembro de 2016.

ASSOCIAÇÃO BRASILEIRA DE TECNOLOGIA GRÁFICA - ABTG -. Manual de indicadores de desempenho ambiental. Disponível em: www.abtg.org.br/download /j463y8f626u6q5n591h8z9m5r3k9h7e7f449f7s3q2p5q. Aceso em 05 de fevereiro de 2017.

ASOCIACIÓN INTERAMERICANA DE INGENIERÍA SANITARIA Y AMBIENTAL AIDIS -. Directrices para la Gestion Integrada y Sostenible de Residuos Solidos Urbanos en America Latina y el Caribe. Asociación Interamericana de Ingeniería Sanitaria y Ambiental - São Paulo: AIDIS/IDRC, 2006.

ASSOCIAÇÃO BRASILEIRA DE NORMAS TÉCNICAS. ABNT -ABNT NBR ISO 9.001: Sistemas de Gestão da Qualidade — Requisitos. Rio de Janeiro, 2008.

ABNT - Informações gerais sobre a ABNT e normas. Disponível em: <www.abnt.org.br> Acesso em outubro de 2016.

ABNT NBR ISO 9.004: Gestão para o Sucesso Sustentado de uma Organização - Uma Abordagem da Gestão da Qualidade. Rio de Janeiro, 2010.

ABNT NBR ISO 14.001: Sistemas de Gestão Ambiental - Requisitos com orientações para uso. Rio de Janeiro, 2004.

ABNT NBR ISO 14.004: Sistemas de Gestão Ambiental - Diretrizes gerais sobre princípios, sistemas e técnicas de apoio. Rio de Janeiro, 2005.

ABNT NBR ISO 14.031: Avaliação de desempenho ambiental - Diretrizes. Rio de Janeiro, 1999.

ALMEIDA, C. M. V. B., BONILLA S. H., GIANNETTI, B. F., HUISINGH, D. Cleaner Production initiatives and challenges for a sustainable world: an introduction to this special volume. Journal of Cleaner Production, Vol 47, p. 1-10. 2013. 
ALVES, S. M.; OLIVEIRA, J.F.G. Adequação ambiental dos processos de usinagem utilizando Produção mais Limpa como estratégia de gestão ambiental. Revista Produção Online. São Paulo. v. 17. jan./abr. 2007.

BALDIN, N.; ORTH, C. M.; ZANOTELLI, C. T. A. geração de resíduos sólidos em um processo produtivo de uma indústria automobilística: uma contribuição para a redução. Gestão \& Produção. São Carlos, v. 21, n. 2. 2014.

BARBIERI, J. C. Gestão ambiental: conceitos, modelos e instrumentos. Ed. Saraiva - $2^{\mathrm{a}}$ edição. São Paulo. 2007.

BARBOSA, Daniele de O. Guia Técnico Ambiental da Indústria Gráfica. 2a. Ed. São Paulo: CETESB: SINDIGRAF, 2009.

BARE, J., HOFSTETTER, P., PENNINGTON, D., \& UDO DE HAES, H. Midpoints versus endpoints: The sacrifices and benefits. [Life cycle impact assessment workshop summary. International Journal of Life Cycle Assessment. 2000.

BARROS, R. T. V. Elementos de Gestão Resíduos Sólidos. Belo Horizonte. 2012.

BEZERRA, F. F. N.; MONTEIRO, M. S. L. Sistema de Gestão Ambiental ou Produção Mais Limpa? Estudo de caso nas indústrias de confecções com lavanderia, Teresina, Piauí. REDE - Revista Eletrônica do Prodema, Fortaleza, v.3, n.1, p-42-61. Junho. 2009.

BOUSQUIN, JUSTIN; ESTERMAN, MARCOS; ROTHENBERG, SANDRA. Life cycle analysis in the printing industry: a review. 2011. Acessado em 14 de fevereiro de 2017. Disponível em: http://scholarworks.rit.edu/books/93.

BANCO NACIONAL DE DESENVOLVIMENTO ECONÔMICO E SOCIAL - BNDES. Apoio às Micro, Pequenas e Médias Empresas. Disponível em: https://web.bndes.gov.br/bib/jspui/bitstream/1408/4261/1/Cartilha\%20MPME\%202 015.pdf. Acesso em: 15 de outubro de 2015.

BRASIL. Portaria MMA no 454, de 28 de novembro de 2003. Visa a promover a Rede Brasileira de Produção mais Limpa e Ecoeficiência, como instrumento de gestão ambiental e modernização do setor produtivo. Diário Oficial (da) República Federativa do Brasil, Ministério do Meio Ambiente, Brasília, DF, 01 dez. 2003.

Lei $n^{\circ}$ 12.305, de 2 de agosto de 2010. Institui a Política Nacional de Resíduos Sólidos - PNRS; altera a Lei no 9.605, de 12 de fevereiro de 1998; e dá outras providências. Diário Oficial (da) República Federativa do Brasil, Brasília, DF. 2010.

Ministério do Meio Ambiente. Guia para elaboração dos Planos de Gestão de Resíduos Sólidos. Brasília, 2011.

BRESSAN, FLÁVIO. O método do estudo de caso. Revista Administração Online, Volume 1 - Número 1. FECAP, São Paulo, 2000. 
BURRIT, R. L.; HERZIG, C.; TADEO, B. D. Environmental management accounting for cleaner production: The case of Philippine rice mill. Journal of Cleaner Production,v. 17, n. 4, p. 431-439, mar. 2009.

CAGNIN, N. K. Environmental Business Management. Genebra: Ilo, 1999.

CAGNO, E.; TRUCCO, P.; TARDINI, L. Cleaner production and profitability: analysis of 134 industrial pollution prevention (P2) project reports. Journal of Cleaner Production. v. 13, n. 6, p. 593-605, maio. 2005.

CALEGARI, E. P. et al. Levantamento dos resíduos gerados na gráfica da UFRGS visando a reutilização de materiais para o desenvolvimento de produtos. Santa Maria, 2015.

CASTILLO, Leonardo; LEÃO, Lucídio Cardoso. Diretrizes para a Avaliação do Desempenho Ambiental da Indústria Gráfica. Revista D.: Design, Educação, Sociedade e Sustentabilidade, Porto Alegre, v. 6 n. 2, 54 - 71, 2014.

CARDOSO, A. O. Introdução ao Plano de Gerenciamento de Resíduos Sólidos - PGRS. Porto Alegre: CNTL/SENAI, 2008. Disponível em: <http://www.senairs.org.br/cntl/> Acesso em: 15 de outubro de 2015.

CENTRO NACIONAL DE TECNOLOGIA LIMPAS, SENAI-RS - CNTL. Série de Manuais de Produção Mais Limpa - Implementação de Programas de Produção mais Limpa. Porto Alegre: UNIDO / UNEP / CNTL, 2003a.

CENTRO NACIONAL DE TECNOLOGIA LIMPAS, SENAI-RS - CNTL. Série de Manuais de Produção Mais Limpa - Questões Ambientais e Produção mais Limpa. Porto Alegre: UNIDO / UNEP / CNTL, 2003b.

CENTRO NACIONAL DE TECNOLOGIA LIMPAS, SENAI-RS - CNTL. Série de Manuais de Produção Mais Limpa - Indicadores Ambientais e de Processo. Porto Alegre: UNIDO / UNEP / CNTL, 2003c.

CENTRO NACIONAL DE TECNOLOGIA LIMPAS, SENAI-RS - CNTL. Série de Manuais de Produção Mais Limpa - Cinco Fases da Implantação de Técnicas de Produção mais Limpa. Porto Alegre: UNIDO / UNEP / CNTL, 2003d.

CENTRO NACIONAL DE TECNOLOGIA LIMPAS SENAI-RS - CNTL. Série de Manuais de Produção Mais Limpa - Sistema de gestão ambiental e produção mais limpa. Porto Alegre: UNIDO / UNEP / CNTL, 2003e.

COMPANHIA DE TECNOLOGIA DE SANEAMENTO AMBIENTAL - CETESB. Prevenção a Poluição. Conceitos e definições.1993. Disponível em: http://www.cetesb.sp.gov.br/Ambiente/prevenção_poluicao/ conceito.asp. Acesso em 10 de outubro de 2015.

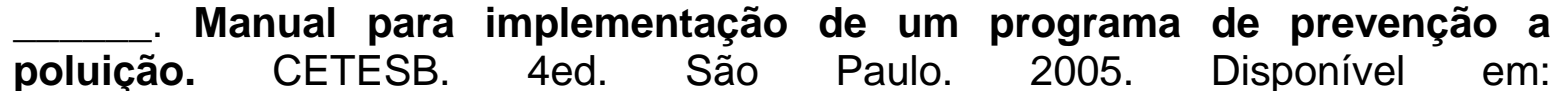
http://www.cetesb.sp.gov.br/Ar/informacoes.asp. Acesso em 15 setembro de 2015. 
CHAVAN, M. An appraisal of environment management systems: a competitive advantage for small businesses. Management of Environmental Quality: An International Journal. v. 16, n. 5, p. 444-463, 2005.

Conselho Empresarial Brasileiro para o Desenvolvimento Sustentável - CEBDS. Guia da produção mais limpa. 2003. Disponível em: http://www.cebds.org.br/. Acesso em: 16 de novembro de 2015.

Conselho Empresarial Brasileiro para o Desenvolvimento Sustentável - CEBDS. A Produção mais Limpa na Micro e Pequena Empresa. Cartilha do SEBRAE sobre Produção mais Limpa. Disponível em: http://www.pmaisl.com.br/publicacoes.asp. Acesso em: 16 de novembro de 2015.

COSTA, I., FERRÃO, P. A case study of industrial symbiosis development using a middle-out approach. Journal of Cleaner Production. 18, 984e992. 2010.

DIAS, Genebaldo Freire. Educação ambiental: princípios e prática. 9. ed. São Paulo: Gaia. 2004.

FAGNANI, E; GUIMARÃES, J. R. Waste management plan for higher education institutions in developing countries: The Continuous Improvement Cycle model. Journal of Cleaner Production. Volume 147, Pages 108-118. 2017.

FERNANDES, J. V. G et al. Introduzindo práticas de produção mais limpa em sistemas de gestão ambiental certificáveis: uma proposta prática. Revista Engenharia Sanitária e Ambiental, v. 06, n. 03, jul/dez. Rio de Janeiro, 2001.

FIJA $Ł, T$. An environmental assessment method for cleaner production technologies. Journal of Cleaner Production, v. 10, n. 1, p. 3-12, fev. 2007.

FRANCHETTI, M. ISO 14001 and solid waste generation rates in US manufacturing organizations: an analysis of relationship. Journal of Cleaner Production, n. 19, p. 1104- 1109. 2011.

FRANK, B.; GROTHE-SENF, A. Avaliação de Desempenho Ambiental Ampliado (ADAA): um modelo para comparação de empresas. Revista Brasileira de Ciências Ambientais. n.5, São Paulo, dez. 2006.

FURTADO, et al. Manual de Prevenção de Resíduos na Fonte \& Economia de água e Energia. São Paulo: Fundação Vanzolini, 1998.

GIANNETTI, B. F., ALMEIDA, C.M.V., Ecologia Industrial, Conceitos ferramentas e aplicações. São Paulo: Editora Edgard Blucher, p. 16, 82-83, 2006.

GOLDEMBERG, J.; PIVA, H. L.; ISOLA, S. R. Guia técnico ambiental da indústria gráfica. São Paulo, 2003.

GALE, R. Environmental costs at a Canadian paper mill: a case of study of Environmental Management Accounting (EMA). Journal of Cleaner Production, 14 (14), p. 1237-1251, jan. 2006. 
GIL, Antônio Carlos. Métodos e técnicas de pesquisa social. 6 ed. São Paulo: Atlas, 200 p. 2008.

HADEN, S.S.P., OYLER, J.D., HUMPHREYS, J.H. Historical, practical, and theoretical perspectives on green management: an exploratory analysis. Journal of Management Decision. Vol 47, P. 1041 - 1055. 2009.

INTERNATIONAL FINANCE CORPORATION - IFC.-Handshake: IFC's quarterly journal on public-private partnerships. Waste PPPs. 2014. Disponível em: <http://www.ifc.org/wps/wcm/connect/81efc00042bd63e5b01ebc0dc33b630b/Hand shake12_WastePPPs.pdf?MOD=AJPERES>. Acesso em: 16 mar. 2016.

KHAN, D.; KUMAR, A.; SAMADDER, S. R. Impact of socioeconomic status on municipal solid waste generation rate. Waste Management, v. 49, p. 15-25, 2016.

LIMA, J. C. F.; RUTKOWSKI, E. W. Evolução das abordagens ambientais industriais. In: International Workshop Advances in Cleaner Production. São Paulo. Anais eletrônicos. São Paulo: UNIP, 2009.

PIMENTA, Handson Claudio Dias; GOUVINHAS, Reidson Pereira. A produção mais limpa como ferramenta da sustentabilidade empresarial: um estudo no estado do Rio Grande do Norte. Produção Online, v. 22, n. 3, p. 462-476, maio/ago. 2012.

HENRIQUES, L. P.; QUELHAS, O. L. G. Produção Mais Limpa: Um exemplo para sustentabilidade nas organizações. 2007.

HICKS, C.; DIETMAR, R. Improving cleaner production through the application of environmental management tools in China. Journal of Cleaner Production, v. 15, n. 5, p. 395- 408, 2007.

JABBOUR, C. J. C.; DA SILVA, E. M.; PAIVA, E. L.; SANTOS, F. C. A. Environmental management in Brazil: is it a completely competitive priority? Journal of Cleaner Production. Vol 21, p. 11-22. 2012.

JABBOUR, C. J. C.; SANTOS, F. C. A.; NAGANO, M. S., Environmental management system and human resource practices: is there a link between them in four Brazilian companies? Journal of Cleaner Production, Vol 16, p. 1922-1925, 2008.

KARLSSON, M., WOLF. A. Using an optimization model to evaluate the economic benefits of industrial symbiosis in the forest industry. Journal of Cleaner Production. 16, 1536e1544. 2008.

KHAN, Z. Cleaner production: an economical option for ISO certification in developing countries. Journal of Cleaner Production. v. 16, n.1, p. 22-27. jan. 2008.

KOLOMINSKAS, C.; SULLIVAN, R. Improving cleaner production through pollutant release and transfer register reporting processes. Journal of Cleaner Production, v. 12, n. 7, p. 713- 724, 2004. 
KJAERHEIM, G. Cleaner production and sustainability. Journal of Cleaner Production, v. 13, n. 4, p. 329-339. 2005.

KLEMĚS, J. J.; VARBANOV, P. S.; HUISING, D. Recent cleaner production advances in process monitoring and optimization. Journal of Cleaner Production, v. 34, p. 1-8, 2012.

KUBOTA, F. I.; ROSA, L. C. Identification and conception of cleaner production opportunities with the Theory of Inventive Problem Solving. Journal of Cleaner Production. N. 47, p. 199-210, 2013.

KUBOTA, F. I.; CAMPOS, M. S.; CAUCHICK-MIGUEL, P. A. Uma análise preliminar das contribuições da modularidade em produto ao Ecodesign. Produção Online, v. 14, n. 2, p. 560-592, 2014.

LARSON, T. J., BROWN, H.J. Designing Metrics That Fit: Rethinking Corporate Environmental Performance Measurement Systems. Environmental Quality Management. Spring issue, p. 81-88. 1997.

LOPES SILVA, D. A.; DELAI, I.; CASTRO, M. A. S.; OMETTO, A. R. Quality tools applied to Cleaner Production programs: a first approach toward a new methodology, Journal of Cleaner Production. Amsterdam, v.47, p.174-187, 2013.

LEE, Y. E.; KOH, K. Decision-making of nuclear energy policy: application of environmental management tool to nuclear fuel cycle. Energy Policy, v. 30, n. 13, p. 1151-1161, out. 2002.

LUNDBERG, K.; BALFORS, B.; FOLKESON, L. Framework for environmental performance measurement in a Swedish sector organization. Journal of Cleaner Production, v. 17, n. 11, p. 1017-1024, Jul. 2009.

MACEDO, Â. P.; VALENÇA, A. C. de V. Indústria Gráfica. Brasília: 1997, BNDES. Disponível em: http://www.bndes.gov.br/conhecimento/relato/grafica.pdf. Acesso em: 16 de outubro de 2015.

MARTINS, Vanessa Fonseca. Sistema de Gestão da Qualidade - Os desafios para a Certificação na Norma ISO 9001:2008. Minas Gerais, 93 p. ,2010. Disponível em: http://www.em.ufop.br/depro/ depro/monografias/2010/2010g.pdf>; Acesso em: outubro de 2015.

MASSOTE, C. H., R. SANTI, A. M. M. Implementation of a cleaner production program in a Brazilian wooden furniture factory. Journal of Cleaner Production. Vol. 46, p. 89-987. 2013.

MEDEIROS, C. Instruções para a elaboração do plano de gerenciamento de resíduos sólidos - PGRS. Centro de Recursos Ambientais, 2002.

MEDEIROS, A. V. Processos gráficos. Belo Horizonte: SENAI/FIEMG, 2013.

MISSIAGGIA, R. R. Gestão de Resíduos Sólidos Industriais: Caso Springer Carrier. Dissertação (Mestrado em Administração) - Programa de Pós-Graduação 
em Administração (PPGA), Universidade Federal do Rio Grande do Sul (UFRGS). Porto Alegre, 2002.

MOURA, L. A. A. Qualidade e Gestão Ambiental - Sustentabilidade e Implantação da ISO 14.001. 5 ed. revista e atualizada. São Paulo: Editora Juarez de Oliveira, 2008.

NAGEL, M. H. Managing the environmental performance of production facilities in the electronics industry: more than application of the concept cleaner production. Journal of Cleaner Production, v. 11, n. 1, p. 11-26, fev. 2003.

NAIME, R. Diagnóstico Ambiental e Sistemas de Gestão Ambiental: incluindo a atualização da série ISO 9000 e as novas NBR 14001/2004 e NBR ISO 19011/2002. Novo Hamburgo: Feevale, 168p, 2005.

NAIME, R.; GARCIA, A. C. A. Percepção ambiental e diretrizes para compreender a questão do meio ambiente. Novo Hamburgo: Feevale, 136p, 2004.

NASCIMENTO, L. F. Gestão Ambiental e Sustentabilidade. Sistema Universidade Aberta do Brasil, 2012.

NIELSEN, S. N. What has Modern Ecosystem Theory to offer to Cleaner Production, Industrial Ecology and Society? The views of an ecologist. Journal of Cleaner Production, 15, p. 1639-1653. 2007.

OLIVEIRA, J. A., GUARDIA, M. et al. Identificação dos benefícios e dificuldades da produção mais limpa em empresas industriais do estado de São Paulo. Revista Produção Online, v. 15, n. 2, p. 458-481. 2015. Disponível em: $<$ http://hdl.handle.net/11449/135835>. Acesso em 06 de outubro de 2015.

OLIVEIRA, J. A. Otimização ambiental de um sistema de produção de petróleo baseada em critérios de produção mais limpa. (Mestrado em Gerenciamento e Tecnologias Ambientais no Processo Produtivo) - Escola Politécnica, Universidade Federal da Bahia, Salvador, 2006.

PRINTING INDUSTRIES ASSOCIATION - PIA. Waste Reduction in the Printing Industry - Final Report. Maio 2003. Disponível em: https://www.piaa.org.au/verve/_resources/Waste_Reduction_in_the_Printing_Indus try.pdf. Acesso em 06 de fevereiro de 2017.

REDE BRASILEIRA DE PRODUÇÃO MAIS LIMPA - PMAISL Guia para a Produção mais Limpa - Faça Você Mesmo. Disponível em: http://www.gerenciamento.ufba.br/ Downloads/ guia-da-pmaisl.pdf. Acesso em 01 de fevereiro de 2017.

PRICEWATERHOUSECOOPERS - PWC. Estudo sobre o setor de tratamento de resíduos industriais. 2006. 
REAP, J., ROMAN, F., DUNCAN, S., \& BRAS, B. A survey of unresolved problems in life cycle assessment. Part 1: Goal and scope and inventory analysis. International Journal of Life Cycle Assessment, 13, 290-300. 2008a.

REAP, J., ROMAN, F., DUNCAN, S., \& BRAS, B. A survey of unresolved problems in life cycle assessment. Part 2: Impact assessment and interpretation. International Journal of Life Cycle Assessment, 13, 374-388. 2008b.

REDMOND, J., WALKER, E., WANG, C., Issues for small businesses with waste management. J. Environmental. Management. 2008.

HINZ, Roberta Tomasi Pires; VALENTINA, Luiz V. DALLA, Ana Claudia Franco. Sustentabilidade ambiental das organizações através da produção mais limpa ou pela Avaliação do Ciclo de Vida. Estudos tecnológicos - Vol. 2, n² 2:91-98. 2006.

ROCCA, A. C. C. Resíduos Sólidos Industriais. 2ed. São Paulo: CETESB, 234p. 1993.

ROSSI, M, T. B. BARATA, M. M. Barreiras à Implementação de Produção Mais Limpa Como Prática de Ecoeficiência em Pequenas e Médias Empresas no Estado do Rio de Janeiro. In II International Workshop Advances in Cleaner Production: cleaner production initiatives and challenges for a sustainable world. São Paulo, 2009.

SANTOS, M. S; YAMANAKA, H. T.; PACHECO, C. E. M. Bijuterias. Série P+L. São Paulo: CETESB, 2005. 54p. Disponível em: <http://www.cetesb.sp.gov.br>. Acesso em: 11 de novembro de 2015.

SCAVONE, G. M. Challenges in internal environmental management reporting in Argentina. Journal of Cleaner Production, v.14, n. 6-7, p. 629-635, 2006.

Serviço Brasileiro de Apoio às Micro e Pequenas Empresas - SEBRAE. Ideias de negócios sustentáveis - gráfica. 2012. Disponível em: http://intranet.df.sebrae.com.br/downloads/ Downloads/. Acesso em Junho/2015.

SEIFFERT, M. E. B. ISO 14001 Sistemas de gestão Ambiental: implantação objetiva e econômica. 3. ed. São Paulo: Atlas, 2007.

SILVA, C.M. Gerenciamento de resíduos sólidos gerados em laboratório de análises clínicas na cidade de Ribeirão Preto, Dissertação (Mestrado em Enfermagem em saúde pública), Escola de Enfermagem de Ribeirão Preto, Universidade de São Paulo, 2008.

SILVA, A. L. E.; MORAES, J. A. R. et al. Proposta de um programa de P+L como ferramenta para promoção da gestão ambiental: estudo de caso. Revista Tecnológica, Santa Cruz do Sul, Vol. 16, n.1, p. 40-47, Jan/Jun. 2012.

SILVA, G. C. S.; MEDEIROS, D. D. Environmental management in brazilian companies. Management of Environmental Quality: An International Journal. v. 15, n. 4, p. 380-388, 2004. 
SILVA, D. A. L., DELAI, I. CASTRO, M. A. S., OMETTO, A. R. Quality tools applied to Cleaner Production programs: a first approach toward a new methodology. Journal of Cleaner Production, Vol 47, p. 174-187. 2013.

SIMIÃO, Juliana. Gerenciamento de resíduos sólidos industriais em uma empresa de usinagem sobre o enfoque da produção mais limpa. Dissertação (Mestrado-Programa de Pós-Graduação em Hidráulica e Saneamento e Área de Concentração em Saneamento) -- Escola de Engenharia de São Carlos da Universidade de São Paulo, 2011.

SINDIGRAF. Manual Técnico-Ambiental da Indústria Gráfica: metodologia de prevenção à poluição, identificação e redução em processos gráficos. Porto Alegre: Gráfica Trindade, 108p. 2006.

SOUZA, I. P. SILVA, M. C. Manual de gestão ambiental para as indústrias gráficas: conhecimento socialmente produzido. Revista Gestão Industrial. № 01: p. 116130, 2008.

SOUTO, J. E.; RODRIGUEZ, A. The problems of environmentally involved firms: innovation obstacles and essential issues in the achievement of environmental innovation. Journal of Cleaner Production, Oxford, v. 101, p. 49-58, 2015.

SONG, Q.; LI, J.; ZENG, X. Minimizing the increasing solid waste through zero waste strategy. Journal of Cleaner Production, Oxford, v. 104, p. 199-210, 2015.

SINGH, M. BRUECKNER, M., PARDHY, P. L. Environmental management system ISO 14001: effective waste minimization in small and medium enterprises in India. Journal of Cleaner Production, Vol 102, p. 285-301. 2015.

SHEN, T. T. Industrial Pollution Prevention. Berlim: Springer - Verlag. 1995.

STANISKIS, J. K.; STASISKIENE, Z. Environmental management accounting in Lithuania: exploratory study of current practices, opportunities and strategic intents. Journal of Cleaner Production. v. 14. p. 1252-1261. 2006.

TAM, V. W. Y.; TAM, C. M.; ZENG, S. X.; CHAN, K. K. Environmental performance measurement indicators in construction. Building and Environment, v. 41, n. 2, p.164-173, fev. 2006.

TANAKA, O. Y. Avaliação de Programas de Saúde do Adolescente: Um Modo de Fazer. São Paulo: Ed. USP, 2001.

TCHOBANOGLOUS, G; THEISEN, H; VIGIL, S. Solid Wastes: Engineering Principles and Management Issues. McGraw - Hill, Inc., 621 p., 1993.

TERRA. G. P.; WASSERMAN, J. C. F. A. Produção mais Limpa Aplicada à Indústria Gráfica: Lições Aprendidas para a Sustentabilidade no Setor. Mestrado Profissional em Sistemas de Gestão. LATEC/UFF Niterói, RJ. 2010. 
TERRA, Gisela Pires; WASSERMAN, Julio César de Faria. Análise crítica de aplicação de práticas de $P+L$. IX congresso nacional de excelência em gestão. 2013.

THIOLLENT, M. Pesquisa-Ação nas organizações. 2ed. São Paulo: Editora Atlas, 2009.

TONDOWSKI, L. O cuidado com as soluções "criativas" Revista Saneamento Ambiental - no 54, p. 16-24, nov./dez. 1998.

TRIPP, D. Pesquisa-ação: uma introdução metodológica. Educação e Pesquisa, São Paulo, v.31, n.3, p.443-466, set./dez. 2005.

UNITED NATIONS ENVIRONMENT PROGRAMME - UNEP. Current changes in approaches to environmental policy: cleaner and leaner production. Disponível em: http://www.unep.org. Acesso em: Outubro/2015.

VELASCO, R. F. A Produção Mais Limpa e seu Impacto Econômico na Sociedade; Engenharia Sanitária e Ambiental, UFSC. Disponível em: http://www.ens.ufsc.br/principal/pdfs/41781bd5d2860e1e6aaad51180f224310c6fb7 d1.pdf. Acesso em: 23 set. 2016.

VERGARA, S. C. Projetos e Relatórios de Pesquisa em Administração. 3ed. São Paulo, Atlas, 2000.

WANG, L; YAN, K.; HU, C. Cleaner production of inkjet printed cotton fabrics using a urea-free ecosteam process. Journal of Cleaner Production, doi: 10.1016/j.jclepro.2016.11.182. 2016.

YIN, R. K. Estudo de caso: planejamento e métodos. $3^{a}$ ed. Porto Alegre: Bookman, 2009.

ZENG S.X., et al. Impact of cleaner production on business performance. Journal of Cleaner Production, Vol 18, pg 975-983. 2010.

ZHI-DONG, L., et al. Evaluation of cleaner production audit in pharmaceutical production industry: case study of the pharmaceutical plant in Dalian, P. R. China. Clean Technologies and Environmental Policy. p.195-206, 2011.

ZURBRÜGG, C.; Gfrerer, M.; Ashadi, H.; BRENNER, W.; Küper, D. Determinants of sustainability in solid waste management - The Gianyar Waste Recovery Project in Indonesia. Waste Management, v.12, 2012. 
11 APÊNDICE_A

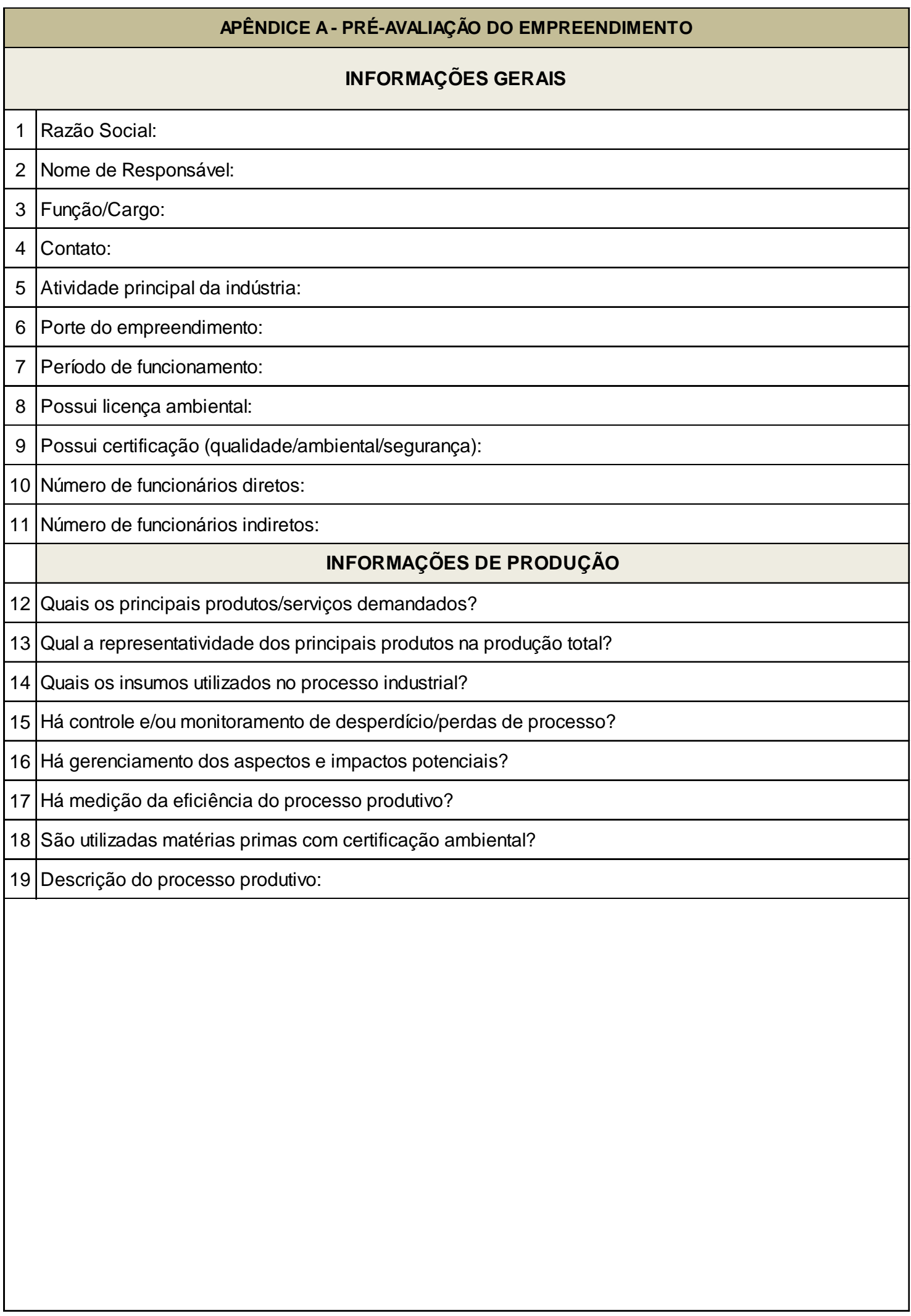


12 APÊNDICE_B

\begin{tabular}{|c|c|c|c|c|c|}
\hline & \multirow{2}{*}{ APÊNDICE B - DIAGNÓSTICO DO GERENCIAMENTO DE RESÍDUOS SÓLIDOS } & \multicolumn{3}{|c|}{ Atendimento } & \multirow{2}{*}{ Obs. } \\
\hline & & Sim & Não & Parcial & \\
\hline \multicolumn{6}{|c|}{ Gestão de Resíduos Sólidos } \\
\hline 1 & Possui Sistema de Gestão Ambiental? & & & & \\
\hline 2 & Tem Plano de Gerenciamento de Resíduos Sólidos implantado? & & & & \\
\hline 3 & Tem um responsável técnico atuando nas questões ambientais? & & & & \\
\hline 4 & Há controle sobre a geração derresíduos sólidos no processo industrial? & & & & \\
\hline 5 & Quais as formas de destinação dada aos resíduos sólidos industriais? & & & & \\
\hline 6 & $\begin{array}{l}\text { Quais as formas de destinação dada aos resíduos sólidos domésticos ou } \\
\text { administrativos? }\end{array}$ & & & & \\
\hline 7 & $\begin{array}{l}\text { São utilizadas empresas licenciadas para a atividade de coleta, transporte e } \\
\text { destinação final? }\end{array}$ & & & & \\
\hline 8 & Identifica e promove ações para redução da geração de resíduos sólidos? & & & & \\
\hline 9 & Identifica e promove ações de melhoria contínua de processos? & & & & \\
\hline \multicolumn{6}{|c|}{ Geração de Resíduos Sólidos } \\
\hline 10 & Conhece todos os pontos de geração de resíduos sólidos da área? & & & & \\
\hline 11 & Há controle sobre a geração de resíduos sólidos ou desperdício de produtos? & & & & \\
\hline 12 & Gera resíduos sólidos perigosos? & & & & \\
\hline 13 & Gera resíduos sólidos não perigosos? & & & & \\
\hline 14 & Realiza segregação diferenciada para os resíduos perigosos e os não perigosos? & & & & \\
\hline 15 & Realiza tratamento prévio de algum resíduo sólido gerado? & & & & \\
\hline 16 & Realiza segregação diferenciada dos resíduos nas áreas? & & & & \\
\hline 17 & Tem programa de coleta seletiva? & & & & \\
\hline 18 & Comercializa os resíduos recicláveis? & & & & \\
\hline 19 & Realiza alguma quantificação/pesagem dos resíduos gerados? & & & & \\
\hline \multicolumn{6}{|c|}{ Manejo e Segregação de Resíduos Sólidos } \\
\hline 20 & Os resíduos são segregados na fonte geradora? & & & & \\
\hline 21 & $\begin{array}{l}\text { Existem procedimentos operacionais para as atividades de coleta interna e } \\
\text { inseridos na rotina? }\end{array}$ & & & & \\
\hline 22 & Recebem ou receberam treinamento sobre manejo e segregação de resíduos? & & & & \\
\hline 23 & Utilizam EPI's? & & & & \\
\hline \multicolumn{6}{|c|}{ Acondicionamento de Resíduos Sólidos } \\
\hline 24 & Os recipientes contenedores suportam a capacidade e são resistentes? & & & & \\
\hline 25 & Há identificação dos acondicionadores conforme classificação do resíduo sólido? & & & & \\
\hline \multicolumn{6}{|c|}{ Armazenamento temporário dos Resíduos Sólidos } \\
\hline 26 & Há local exclusivo para armazenamento temporário dos resíduos sólidos? & & & & \\
\hline 27 & São armazenados na área somente os resíduos do processo industrial? & & & & \\
\hline 28 & No local há separação de resíduos reciclaveis dos não recicláveis e dos perigosos? & & & & \\
\hline 29 & O local possui piso impermeabilizado e sistema de contenção/drenagem? & & & & \\
\hline 30 & Há acúmulo excessivo de resíduos sólidos? & & & & \\
\hline 31 & Considera o ambiente organizado? & & & & \\
\hline 32 & Há rotina operacional de higienização da área de armazenamento? & & & & \\
\hline \multicolumn{6}{|c|}{ Armazenamento Externo para Resíduos Sólidos } \\
\hline 33 & Existe área de armazenamento externo dos resíduos sólidos? & & & & \\
\hline 34 & Há acúmulo excessivo de resíduos sólidos? & & & & \\
\hline 35 & Considera o ambiente organizado? & & & & \\
\hline 36 & Há rotina operacional de higienização da área de armazenamento? & & & & \\
\hline
\end{tabular}


Coleta, Transporte, Destinação final

37 A coleta e transporte externo são realizados por veículos específicos e identificados para a atividade atendendo as legislações?

38 O tratamento e disposição final dos resíduos sólidos é realizado por empresa licenciada e autorizada pelos órgãos competentes?

39 Recebe a certificação do tratamento e/ou da disposição final dos resíduos?

Segurança e Saúde do Trabalhador

40 Existe profissional responsável pelas questões de saúde e segurança ocupacional?

41 Tem registro e controle de acidentes ambientais?

42 Possui mapa de riscos ocupacionais e ambientais?

43 Programa de Prevenção de Riscos Ambientais - PPRA, PCMSO, outros?

Monitoramento e controle

44 Há processo de monitoramento e controle sobre a geração de resíduos sólidos?

45 Realiza a pesagem de todos os resíduos periodicamente?

46 Há procedimento para monitoramento de desperdício de produção?

47 Utiliza dados comparativos dos resíduos gerados com outras industrias?

48 Há quantificação relacionada ao desperdício e geração de resíduos sólidos

49 Observa oportunidade de evolução na área? Quais?

Gestão do consumo de insumos

50 Realiza Gestão de Racionamento de Consumo de insumos (energia elétrica, água, 50 lâmpada fluorescente, papel, etc.)?

51 Existe cronograma de limpeza e desinfecção dos reservatórios de água?

52 Realiza gerenciamento de limpeza de bebedouros e galões de água?

53 Realiza gerenciamento dos materiais/equipamentos (torneira economizadora,

sensores de presença e etc.) que proporciona redução de água e energia elétrica?

54 Há programa de substituição de equipamentos elétricos, hidráulicos e eletrônicos, por exemplo, ar condicionado e geladeira?

55 Faz acompanhamento do consumo de água e energia?

56 Realiza conscientização do consumo racional de água e energia?

Espaço para anotações 
13 APÊNDICE_C

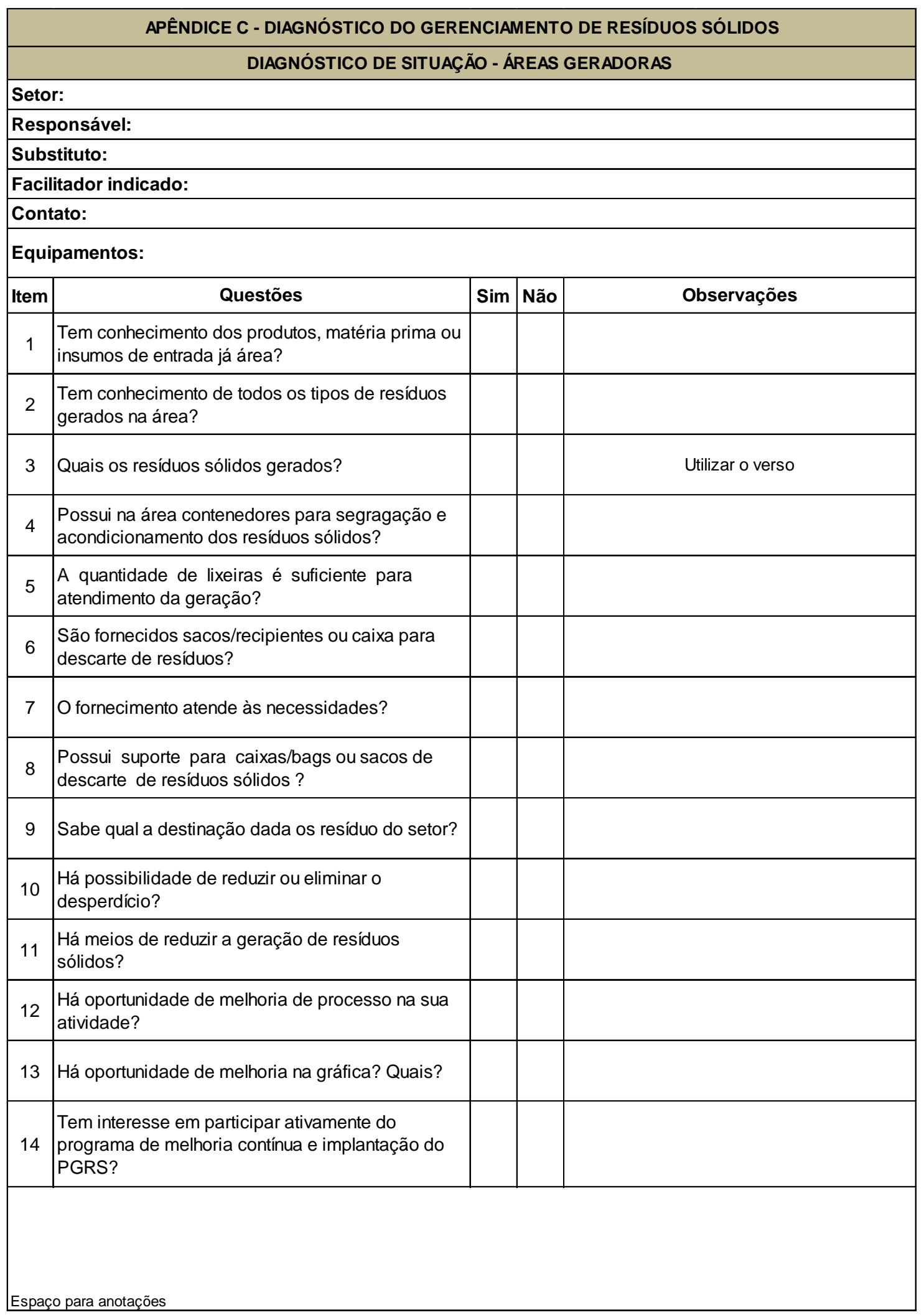


14 APÊNDICE_D

\begin{tabular}{|c|c|c|c|c|c|c|c|c|c|c|c|}
\hline \multicolumn{4}{|c|}{ APÊNDICED } & \multicolumn{2}{|c|}{ FORMULÁRIO } & \multicolumn{6}{|c|}{ FLUXO DE CONTROLE E MEDIÇÃO } \\
\hline Data & Área & Equipamento & $\begin{array}{c}\text { Material de } \\
\text { entrada }\end{array}$ & Vol/Peso & Material de saída & Vol/Peso & $\begin{array}{c}\text { Acondicio } \\
\text { namento }\end{array}$ & $\begin{array}{c}\text { Status da } \\
\text { segregação }\end{array}$ & $\begin{array}{l}\text { Destinaçãol } \\
\text { Armazenamento }\end{array}$ & $\begin{array}{l}\text { Facilitador } \\
\text { (colaborador) }\end{array}$ & Observações \\
\hline & & & & & & & & & & & \\
\hline & & & & & & & & & & & \\
\hline & & & & & & & & & & & \\
\hline & & & & & & & & & & & \\
\hline & & & & & & & & & & & \\
\hline & & & & & & & & & & & \\
\hline
\end{tabular}

